\title{
SELECTIVE MEMORY: AN ANALYSIS OF ALBUMS COMPILED AT THE RETURN OF THE 1904 YOUNGHUSBAND MISSION INTO TIBET
}

by

\author{
Catherine Lachowskyj
}

BA Buddhist Studies, University of Toronto, 2014

\author{
A thesis \\ presented to Ryerson University \\ in partial fulfillment of the \\ requirements for the degree of \\ Masters of Arts \\ in the Program of
}

Film \& Photography Preservation and Collections Management

Toronto, Ontario, Canada, 2016

(C) Catherine Lachowskyj 2016 


\section{Author's Declaration}

I hereby declare that I am the sole author of this thesis. This is a true copy of the thesis, including any required final revisions, as accepted by my examiners.

I authorize Ryerson University to lend this thesis to other institutions or individuals for the purpose of scholarly research.

I further authorize Ryerson University to reproduce this thesis by photocopying or by other means, in total or in part, at the request of other institutions or individuals for the purpose of scholarly research.

I understand that my thesis may be made electronically available to the public.

Catherine Lachowskyj 
Abstract

Selective Memory: An Analysis of Albums Compiled at the Return of the 1904 Younghusband Mission into Tibet

Master of Arts, 2016

Catherine Lachowskyj

Film \& Photographic Preservation and Collections Management

Ryerson University

Focusing on a collection of albums at the Archive of Modern Conflict related to the Younghusband Mission in Tibet (1903-1904), this thesis explores the the analysis of personal albums and their contribution to the history of the Mission. The first chapter, a literature survey, outlines the existing textual histories of the invasion, highlighting the absence of photographic analysis in the works, while also highlighting Tibet's absence from contemporary criticisms of colonial photography. The second chapter is an overview of the visual conventions ascribed to Tibetans in British India's photography prior to the Younghusband Mission, and the third chapter provides provenance information and detailed descriptions of the AMC's albums. Finally, the fourth chapter discusses the objects, revealing their contribution to the perpetuation of Tibetan tropes, implicit visual documentation of British superiority, and the development of constructed narratives favouring the British colonizers. Each analysis acts as an example of how photographs should be used to articulate the colonial history of not only the Younghusband Mission, but of Tibet's greater history with the West. 


\section{Acknowledgements}

First and foremost, thank you Maia Sutnik for your enthusiasm throughout the development and execution of this project. Maia's attentive eye and incredible knowledge of photography's history pushed me in directions I was apprehensive to follow, and helped me reign in my thoughts when they became too broad. Steven Evans also provided great support and many helpful insights as the second reader of my thesis.

I'd like to thank David Franklin and Michelle Wilson at the Archive of Modern Conflict, who organized the transportation of my thesis materials from the London office to Toronto.

Additional thanks to Michelle for patiently explaining the AMC's cataloguing standards and methods, and for allowing me to digitize all of the necessary materials for this project.

Thanks to John Falconer at the British Library for helping me navigate the institution's databases remotely, and for pointing me in the direction of materials I wouldn't have access to otherwise. Additionally, thank you Marja Stijkel, who pulled material from the Rijksmuseum's photographic archive that I had no idea existed. Marja's thoughtful selections revealed a great deal of information that became invaluable for this project.

Finally, thank you to my parents for supporting me in every professional decision I have made, including the pursuit of a BA in Buddhist Studies. It would have been impossible to complete this thesis without their support. 
Author's Declaration

Abstract

Acknowledgements

Table of Contents

List of Tables

List of Figures

List of Appendices

Introduction

Chapter 1: Literature Survey

Primary Accounts of the Younghusband Mission

Biographies and Monographs

Contemporary Analyses of British Colonial Photography

Publications on the Colonial Photography of Tibet

Chapter 2: The Photographic Construction of Tibet

Ethnographic Photography

Studio Photography

Exploratory Photography

The Younghusband Mission Photographs

Chapter 3: The Gollection

Album from Tibet Expedition, 1904

The Hayman Album

Methodology \& Initial Observations

Chapter 4: Analysis

40

Analysis I: Photographing Tibetans

Posing

Anonymization

Constructing Candid Moments Outside of the Studio

Analysis II: Implicit Superiority

Bridges

British Forts vs. Tibetan Structures

Technology

A Note on Landscapes 
Analysis III: Constructed Narratives \& Relationships

The Gravesite

The Chumbi Valley

Tibetan Staff \& British Officials

Conclusion

Appendix A

71

Appendix B

86

Appendix C

101

Appendic D

105

Bibliography

107 


\section{List of Tables}

Table 1 Detailed Caption Variants from Both Albums

51

Table 2 All Captions Referencing the Chumbi Valley 


\section{List of Figures}

All figures in Chapter 4 are reproductions of photographs and album pages from the collection of the Archive of Modern Conflict (AMG), Toronto, Canada.

\begin{tabular}{|c|c|c|}
\hline Fig. 1 & $\begin{array}{l}\text { Unidentified Photographer, Bhotanese Man, 1868, from the section "Bhootan and the Bhootanese" in The People of India } \\
\text { (London: India Museum, 1868). Mounted albumen print. Amsterdam, Rijksmuseum.* }\end{array}$ & 20 \\
\hline Fig. 2 & $\begin{array}{l}\text { Unidentified Photographer, Group of Bhotanese, 1868, from the section "Bhootan and the Bhootanese" in The People of India } \\
\text { (London: India Museum, 1868). Mounted albumen print. Amsterdam, Rijksmuseum.* }\end{array}$ & 20 \\
\hline Fig. 3 & $\begin{array}{l}\text { Unidentified Photographer, Tibetan Man, 1868, from the section "Tibetan-Bhotias" in The People of India (London: India } \\
\text { Museum, 1868). Mounted albumen print. Amsterdam, Rijksmuseum.* }\end{array}$ & 22 \\
\hline Fig. 4 & $\begin{array}{l}\text { Unidentified Photographer, Bhotanese Man, 1868, from the section "Tibetan-Bhotias" in The People of India (London: India } \\
\text { Museum, 1868). Mounted albumen print. Amsterdam, Rijksmuseum.* }\end{array}$ & 22 \\
\hline Fig. 5 & $\begin{array}{l}\text { Unidentified Photographer, Bhotia Female, 1868, from the section "Tibetan-Bhotias" in The People of India (London: India } \\
\text { Museum, 1868). Mounted albumen print. Amsterdam, Rijksmuseum.* }\end{array}$ & 22 \\
\hline Fig. 6 & Benjamin Simpson, A Tibetan Monk in Northeast India, ca. 1860-62. Albumen print. London, Royal Geographical Society. & 23 \\
\hline Fig. 7 & $\begin{array}{l}\text { Late nineteenth century postcard depicting an itinerant Tibetan monk, photographed in India, from Clare E. Harris, The } \\
\text { Museum on the Roof of the World (Chicago: Chicago University Press), } 94 .\end{array}$ & 25 \\
\hline Fig. 8 & Henri D’Orléans, Nomad in sheepskin chuba, Changthang, 1890. Albumen print. & 27 \\
\hline Fig. 9 & Henri D’Orléans, Officials from Lhasa, north of Lhasa, 1890. Albumen print. & 27 \\
\hline Fig. 10 & Henri D'Orléans, Attendant to the Chinese Amban (representative of the Manchu emperor), north of Lhasa, 1890. Albumen print. & 27 \\
\hline Fig. 11 & John Claude White, Glacier at the head of Langpo Valley, Sikkim-Tibet border, 1902. Platinum print. & 29 \\
\hline Fig. 12 & John Claude White, View up Langpo River, Sikkim-Tibet border. 1902. Platinum print. & 29 \\
\hline Fig. 13 & John Claude White, Nuns at the nunnery of Tatsang. 1903. Platinum print. & 30 \\
\hline Fig. 14 & John Claude White, Kampa Dzong, fortress in southern Tibet, 1903. Platinum & 30 \\
\hline Fig. 15 & Front cover of Album From Tibet Expedition, 1904. & 33 \\
\hline Fig. 16 & Inside cover of Album From Tibet Expedition, 1904. & 33 \\
\hline Fig. 17 & Example of window mounts used in Album From Tibet Expedition, 1904. & 34 \\
\hline Fig. 18 & Front cover of the Hayman Album. & 36 \\
\hline Fig. 19 & Inside mount detail of the Hayman Album. & 36 \\
\hline Fig. 20 & Left: A Takin of Bhutan, Album From Tibet Expedition, 1904. Right: A Takin of Bhutan, Hayman Album. Collodion prints. & 37 \\
\hline Fig. 21 & Left: Tibetan Women, Album From Tibet Expedition, 1904. Right: Tibetan Women, Hayman Album. Collodion prints. & 43 \\
\hline Fig. 22 & Left: Tibetan Girl, Album From Tibet Expedition, 1904. Right: Tibetan Girl Hayman Album. Collodion prints. & 45 \\
\hline Fig. 23 & $\begin{array}{l}\text { Left: Group of Tibetan Women + Children, Album From Tibet Expedition, 1904. Right: A Group of Tibetans, Hayman Album. } \\
\text { Collodion prints. }\end{array}$ & 46 \\
\hline Fig. 24 & $\begin{array}{l}\text { Left: Tibetan Women + Children, Album From Tibet Expedition, 1904. Right: Tibetan Women and Children, Hayman Album. } \\
\text { Collodion prints. }\end{array}$ & 47 \\
\hline Fig. 25 & Left: Tibetan Urchins, Album From Tibet Expedition, 1904. Right: Tibetan Urchins, Hayman Album. Collodion prints. & 49 \\
\hline Fig. 26 & $\begin{array}{l}\text { Left: Teesta Bridge (Sikkim), Album From Tibet Expedition, 1904. Right: Teesta Bridge Sikkim, Hayman Album. Collodion } \\
\text { prints. }\end{array}$ & 55 \\
\hline Fig. 27 & $\begin{array}{l}\text { Left: Cantilever Bridge (Chumbi), Album From Tibet Expedition, 1904. Right: Cantilever Bridge, Chumbi, Hayman Album. } \\
\text { Collodion prints. }\end{array}$ & 55 \\
\hline Fig. 28 & $\begin{array}{l}\text { Left: Political Officers House (Chumbi), Album From Tibet Expedition, 1904. Right: The Residency, Chumbi, Tibet, Hayman } \\
\text { Album. Collodion prints. }\end{array}$ & 56 \\
\hline Fig. 29 & $\begin{array}{l}\text { Left: Field Telegraph Office, Chumbi (Tibet), Album From Tibet Expedition, 1904. Right: Field Telegraph Office (Chumbi), } \\
\text { Hayman Album. Collodion prints. }\end{array}$ & 56 \\
\hline Fig. 30 & $\begin{array}{l}\text { Left: Tent of Tashi Lama (Tibet) (Leopard skin), Album From Tibet Expedition, 1904. Right: Tashi Lama's Tent (Leopard } \\
\text { skin), Hayman Album. Collodion prints. }\end{array}$ & 57 \\
\hline Fig. 31 & $\begin{array}{l}\text { Left: Monastery at Gyantse (Tibet), Album From Tibet Expedition, 1904. Right: Tibetan Monastery, Hayman Album. Collodion } \\
\text { prints. }\end{array}$ & 58 \\
\hline Fig. 32 & $\begin{array}{l}\text { Left: Ruins of Phari Jong (Tibet), Album From Tibet Expedition, 1904. Right: Ruins of Phari Jong, Hayman Album. Collodion } \\
\text { prints. }\end{array}$ & 59 \\
\hline Fig. 33 & $\begin{array}{l}\text { Left: Field Telephone at work (Tibet Exp 1904), Album From Tibet Expedition, 1904. Right: Field Telephone at work } \\
\text { (Tibetan Expedition 1904), Hayman Album. Collodion prints. }\end{array}$ & 61 \\
\hline Fig. 34 & $\begin{array}{l}\text { Left: Chumbi Valley \{showing Amo Chu), Album From Tibet Expedition, 1904. Right: Chumbi Valley (looking N), Hayman } \\
\text { Album. Collodion prints. }\end{array}$ & 1 \\
\hline Fig. 35 & $\begin{array}{l}\text { Left: Graves of officers and men who fell during the Tibet expedition, 1904, Album From Tibet Expedition, 1904. Right: } \\
\text { Graves of Officers and men who fell at Gyantse (Tibet Expedition 1904). Hayman Album. Collodion prints. }\end{array}$ & 64 \\
\hline g. 36 & Left: Transport Section, Native Field Hospital, Album From Tibet Expedition, 1904. Right: Transport, Native Field Hospital. & 67 \\
\hline
\end{tabular}


Hayman Album. Collodion prints.

Fig. 37 Left: Telegraph Staff Phari (Tibet), Album From Tibet Expedition, 1904. Right: Telegraph Staff Phri. Hayman Album. Collodion prints.

*Captions as listed correspond to the titles assigned by the Rijksmuseum. 


\section{List of Appendices}

\begin{tabular}{l|l|l} 
Appendix A & Catalogue of the Album from Tibet Expedition, 1904 & $\mathbf{7 1 - 8 5}$
\end{tabular}

Appendix B Catalogue of the Hayman Album

86-100

Appendix C

Transcript of the Treaty of Lhasa

101-104

Appendix D

Photograph Variants by Caption \& Identifier

105-106 


\section{Introduction}

During the Victorian era, the region of Tibet was a coveted destination for explorers.

Bordered to its north by China and surrounded by four massive mountain ranges, the 2.5 million square kilometre landscape was especially attractive to prospective colonizers from British India and Czarist Russia. ${ }^{1}$ In particular, George Curzon, Viceroy of India, pushed for the establishment of a military incursion of the mysterious landscape as an addition to the British Empire. ${ }^{2}$ On December 11, 1903, twenty-five hundred troops and over ten thousand porters assembled by the British Indian government scaled the Himalayas with "seventeen thousand beasts of burden, including yaks and buffaloes." ${ }^{3}$ The resulting invasion officially came to a close on August 3, 1904, when Lieutenant Colonel Francis Younghusband signed a treaty in the Potala Palace "[where] the Tibetan government acquiesced to British demands for greater access to their country and improvements in trading relations." ${ }^{4}$ This short-lived imperial looting expedition, referred to as the Younghusband Mission, was documented by both official and amateur photographers, who produced the first cohesive body of photographs of Tibet available to the Commonwealth.

A few independent explorers had managed to pass through the region's borders in the years prior to the invasion while undertaking minor expeditions. While some of these explorers photographed Tibet, none produced a body of work as substantial as the photographers of the large-scale British invasion. Simultaneously, a commercial and anthropological body of

\footnotetext{
${ }^{1}$ Tibetan Young Buddhist Assocation, Tibet: The Facts (Dharamsala: Indraprastha Press, 1990), 1-3.

${ }^{2}$ At the turn of the twentieth century, rumours alleging a potential alliance between Russia and Tibet for the purposes of arms transportation had become rampant: "It was to Tibet, however, that the focus of the Great Game now shifted, as word was received in India that twice within twelve months an emissary from the Dalai Lama had visited St Petersburg, where he had been warmly welcomed by the Tsar." Peter Hopkirk, The Great Game: The Struggle for Empire in Central Asia (New York: Kodansha USA, Inc., 1994), 505.

${ }^{3}$ Clare E. Harris, The Museum on the Roof of the World: Art, Politics, and the Representation of Tibet (Chicago: University of Chicago Press, 2012), 50.

${ }^{4}$ Ibid, 50.
} 
photographic work had been developed in British India that articulated "Tibetaness" for European visual consumption. Because access to Tibet for commercial photography was difficult, individuals residing in the Himalayan foothills of British India were photographed as Tibetan substitutes. This process of selection and substitution contributed heavily to the visual tropes that became associated with Tibet during the Younghusband Mission. ${ }^{5}$

Official photographs documenting the mission are still available for research and viewing at two major British institutions: the British Library and Royal Geographical Society (both in London). These photographs, consisting primarily of platinum and collodion prints, are usually bound in albums accompanied by general captions. The collections also include glass slides and negatives. Monographs of the Younghusband Mission that accompany these photographs can generally be described as histories rife with storytelling, a trend not uncommon to the documentation of imperial exploration. While these publications sometimes include photographs taken during the Younghusband Mission, they are used as illustrations incorporated within the text.

In the 1950s, western interest in Tibet surged to great heights, due in large part to publications generated from the American Beat Generation, which incorporated Tibetan Buddhism and spirituality into a philosophy of bohemian hedonism. ${ }^{6}$ This re-established interest in Tibet coincided with the exile of the Dalai Lama in 1959, and the official photographs taken during the Younghusband Mission found a new platform for consumption through public

\footnotetext{
5 These perceptions of mysticism and religion often still define the region today, and investigative journalists who have published on China's current colonization of Tibet refer to this romanticization as "Shangri-La Syndrome." See Don Lopez Jr. "No Shangri-La for Tibetans: Romanticizing Tibet Only Obscures the Real Issues," Radio Radicale, May 5, 2008, accessed July 15, 2016, http:/ /www.radioradicale.it/exagora/no-shangri-la-for-tibetansromanticizing-tibet-only-obscures-the-real-issues

${ }^{6}$ In particular, see Jack Kerouac's Dharma Bums, in which the protagonist Ray Smith relates a number of the novel's events to Buddhism. Jack Kerouac, Dharma Bums (New York City: The Viking Press, 1958).
} 
exhibitions and accompanying catalogues. ${ }^{7}$ However, primarily due to their inaccessibility, amateur and personal albums were typically not included or addressed in these academic texts and exhibitions, meaning they were absent from the constructed history of the Younghusband Mission altogether.

Despite their use as secondary sources, photographs of Tibet were exhibited as primary objects in the Pitt Rivers exhibition Seeing Lhasa: British Depictions of the Tibetan Capital 1936-1947, displayed from September 2003 to November 2004. While this interpretation resulted in a critical evaluation of the creation of the images (in both the field of Tibetan Studies and historical photography), their focus excluded images from the Younghusband Mission, as the exhibition centered on photographs housed at the Pitt Rivers Museum. Despite the absence of Younghusband Mission imagery, it was the first photographic exhibition to question the western production and perpetuation of Tibetan tropes in photography.

In recent years, albums and looted objects have started to reappear at auction. In 2013, an album compiled by John Claude White (1853-1918)-Deputy Commissioner of the Tibet Frontier Commission — sold at Bonham's for $\mathcal{E} 38,400,{ }^{8}$ and photographs documenting the Mission have shown an increasing presence and value in the art market. There are interesting consistencies between the different types of albums, including the subject matter of each photograph, as well as their assigned captions.

\footnotetext{
${ }^{7}$ In 1953, Elaine Tankard, curator at the Liverpool Museum, created an exhibition on a major donation by Charles Bell, who had been a senior colonial officer in the Himalayas in the early 1900s. The exhibition consisted of a number of Bell's albums (full of photographs taken by John Claude White), as well as many Tibetan objects that Bell had looted during his post in the region. Clare E. Harris quotes Tankard's unpublished catalogue manuscript, which states that the Younghusband Mission had become a military campaign only "when the Tibetans refused to negotiate [and] offered active resistance." The photographs included in the exhibition were used to "embellish the exhibition space" in service of the artifacts. It should be noted that Tankard's intent was to paint Tibet in a positive light by glorifying Tibetan Buddhism as a rich (but antiquated) practice. See Harris, The Museum on the Roof of the World, 122-23.

8 "Lot 224," Bonhams, accessed July 1, 2016, http://www.bonhams.com/auctions/18061/lot/224/
} 
Even with these problematic shifts in interpretations of imagery of Tibet, personal albums depicting the Younghusband Mission have not been incorporated into any recent histories of the 1904 invasion. These personal souvenirs of the Mission offer a platform for analyzing the intentions and relationships that informed the expedition. The editing and construction of personal albums, assembled in relation to the intentions of the imperial mind, reify some interesting questions: What do the photographs tell us about the social and political values of British colonizers? How are their aspirations reflected in the accompanying captions? How do these personal objects contribute to the visual conventions ascribed to Tibet and Tibetans? And finally, how are the images relevant to our current understanding of Tibet? Focusing on a collection of personal photographic albums compiled during the Younghusband Mission housed at the Archive of Modern Conflict in Toronto, this thesis explores the necessity of incorporating the analysis of amateur photography into histories of the Younghusband Mission. 


\section{Ghapter 1: Literature Survey}

The photographs of John Claude White (1853-1918) are the most popular images used to illustrate the history of the Younghusband Mission, and many are available to access for primary research at both the British Library and the Royal Geographical Society. Since 1903, the photographs have been appropriated in texts and exhibitions as Western readings of Tibet. Though there has been an increase in scholarship over the last twenty years dedicated to exposing the implications of colonial photography, White's photographs of Tibet are usually absent from this discussion, since larger bodies of work created in British India were deemed more relevant for this contemporary criticism.

This literature survey examines how scholars have represented the history of the Younghusband Mission, and the ways in which the photographs taken during the mission are included in these histories. Interpretations are provided through the analysis of publications written by mission members, biographies and monographs related to Younghusband and the mission, contemporary analyses of British colonial photography, and texts specifically concerned with colonial photography of Tibet.

\section{Primary Accounts of the Younghusband Mission}

As was custom with most British colonial invasions, leading figureheads of expeditions often wrote detailed accounts of their adventures upon their return to the Commonwealth, and submitted their archives to national institutions for official safekeeping. Francis Younghusband's personal papers are housed at the British Library in London, consisting of correspondence, diaries, and logs. However, none of these primary materials include photographs.

In 1909, Younghusband published a 530-page book titled India and Tibet: A History of the Relations Which Have Subsisted Between the Two Countries from the Time of Warren Hastings to 1910; With 
a Particular Account of the Mission to Lhasa of $1904 .{ }^{9}$ In his preface, Younghusband describes the invasion as an attempted "establishment of ordinary neighbourly intercourse with Tibet." 10 On the other hand, in a chapter titled "Fear of Tibetan Attack," he justifies the warfare that occurred in spite of his "neighbourly" attempts at negotiations:

At Khamba Jong itself no progress was being made. There was, indeed, fear at one time that we should be attacked, and I have not much doubt that we should have been if we had shown any slackness or unguardedness. ${ }^{11}$

The maps and images included in this volume are secondary to Younghusband's text, having been inserted as corresponding illustrations to the author's textual descriptions of events. Beyond this, the book does not include an explanation of the role of photography in the mission.

John Claude White also wrote on the mission in his book Sikhim \& Bhutan: Twenty-One Years on the North-East Frontier, 1887-1908. ${ }^{12}$ Having photographed prolifically during his time spent as a political officer of British India, the images used in his publication are mostly his own. He therefore references the images more often than Younghusband, including anecdotes and stories related to his taking certain photographs. ${ }^{13}$ This recognition of the process of photographing, however, does not prevent White from glossing over many of the tragic and oppressive events that resulted from his role as Deputy Commissioner during the invasion.

\section{Biographies and Monographs}

Peter Hopkirk, a well-travelled British reporter who worked for nearly twenty years at The London Times, has written a number of books and articles on the Younghusband Mission and the colonial history of Tibet. In Trespassers on the Roof of the World: The Secret Exploration of Tibet (1982),

\footnotetext{
${ }^{9}$ Francis Edward Younghusband, India and Tibet: A History of the Relations Which Have Subsisted Between the Two Countries from the Time of Warren Hastings to 1910; With a Particular Account of the Mission to Lhasa of 1904 (London: J. Murray, 1909).

10 Ibid, vii.

11 Ibid, 125.

${ }^{12}$ John Claude White, Sikhim $\&$ Bhutan: Twenty-One Tears on the North-East Frontier, 1887-1908 (London: Arnold, 1909).

${ }^{13}$ For example, see White's writings on his photograph of the Taktsang nuns on page 25-26 of this thesis.
} 
he recounts (with masterful storytelling) the attempts made to reach and explore Tibet during the Victorian era. In his chapter "Lhasa - at Last," a history of the Younghusband Mission is presented. Hopkirk spends a significant amount of time on character development of certain British mission members in his writings on the Great Game. He says of Younghusband:

...this brilliant young Indian Army officer seemed to possess all the qualities required of a romantic hero of the late Victorian or early Edwardian era. Soldier, explorer, athlete and writer, he had already made a name for himself by the age of twenty-five. ${ }^{14}$

Some photographs are also included in the chapter on the Younghusband Mission, though they often act as mere illustrations that complement his writing style. ${ }^{15}$

Hopkirk also includes a brief history of the Younghusband Mission in his book The Great Game: The Struggle for Empire in Central Asia (1990). Written and published a number of years after Trespassers, much of the information and images pertaining to Younghusband and the invasion are similar if not identical to those found in the first history. ${ }^{16}$

Peter Fleming's Bayonets to Lhasa: The British Invasion of Tibet (1961) is another monograph of the Younghusband Mission that romanticizes Francis Younghusband's character and his namesake invasion. A journalist and travel writer (much like Hopkirk), Fleming outlines an account of the Mission by questionably framing Younghusband as a Tibetan sympathizer:

It had taken him more than a year to get a treaty out of the Tibetans; it had been signed with pomp and finality in the Potala and the Tibetans were perfectly

\footnotetext{
${ }_{14}$ Peter Hopkirk, Trespassers on the Roof of the World: The Secret Exploration of Tibet (London: John Murray, 1982), 159.

${ }^{15}$ For example, an image of three Tibetan men is included in the chapter, all shown with their tongues sticking out. The image has been captioned "Traditional Tibetan greeting" by Hopkirk. The only other information provided about the image is included in the section "Sources of Illustrations" at the front of the book, which states that the image was taken from Sven Hedin's Trans-Himalaya (Macmillan, 1909). See Hopkirk, Trespassers on the Roof of the World, 167.

${ }^{16}$ Hopkirk again romanticizes the character of Younghusband, best exemplified in the paragraph: "Indeed he might almost have been a model for such John Buchan heroes as Richard Hannay and Sandy Arbuthnot—men who pitted themselves single-handed and in lonely places against those threatening the British Empire...Early in his career he was spotted by his superiors as a natural for intelligence work, and while still in his twenties he carried out a number of successful reconnaissances on and beyond the frontier, Such activities, however, were in his blood, for he was the nephew of that earlier player in the Great Game, Robert Shaw, whose career he had dreamed since boyhood of emulating." See Hopkirk, The Great Game, 447.
} 
satisfied with it. His [Younghusband's] farewells had been made, gifts exchanged, prayers said for him in the monasteries. ${ }^{17}$

As will be evidenced in other sections of this thesis, the Tibetan regents were in fact forced to sign the treaty with Younghusband after the British massacred thousands of men in a series of battles with the Tibetan forces. A selection of images are placed in the center of Fleming's text, though these primarily consist of portraits of main British players, as well as generalized photographs of Tibetans. White took a number of the included photographs, although Fleming does not indicate this in the text. ${ }^{18}$

The most popular biography of Younghusband is Patrick French's Younghusband: The Last Great Imperial Adventurer (1994). ${ }^{19}$ A British writer and historian, French spent a number of years in Central Asia travelling and researching the life and times of Francis Younghusband. His biography has won a number of awards ${ }^{20}$, and he is acclaimed for his entertaining candor in the presentation of his intensive research. A number of photographs are included in the illustrated sections of the text, although the role of the practice of photography during the mission is never addressed. Once again, the images were not addressed as objects of analysis that could contribute to the mission's history. ${ }^{21}$ For example, an image of an older Younghusband in Britain has been captioned: "At Ease With The Universe. Younghusband reclines in an armchair, contemplating the realms of the spirit." 22

\footnotetext{
17 Peter Fleming, Bayonets to Lhasa: The British Invasion of Tibet (London: Rupert Hart-Davis Ltd., 1961), 249.

${ }^{18}$ In fact, the image of the nuns of Takstang Monastery (discussed on pg. 25-26 of this thesis), also a favourite of White's, has been included as an illustration. It appears on the same page of an image of three monks, and has been generalized with the page's caption: "Monks and Nuns." Ibid, fourth page in plates section.

${ }_{19}$ Patrick French, Younghusband: The Last Great Imperial Adventurer (London: HarperCollins Publishers, 1994).

20 To date, the book has won the Somerset Maugham Award and the Royal Society of Literature's W. H. Hienemann Prize. Both are literary awards based in England.

21 Though photography is not discussed, French does speak on J.C. White quite often, primarily by expanding on the Political Officer's personality. For example, he initially describes White as "an arrogant, opinionated character, with the customary walrus moustache." French, Tounghusband, 163.

22 Ibid, second plate grouping, 8.
} 
Though these specialized texts serve to document the history of the Younghusband Mission for a contemporary audience, their flavour as travel histories romanticizes and distracts from many of the important historical events that took place during the invasion at the command of Colonel Younghusband himself. The authors' use of photographs as illustrations for their own written text is problematic, as this use of imagery extends the colonial practice of trivializing the role of British photography during the mission to a contemporary readership.

\section{Contemporary Analyses of British Colonial Photography}

Though the material analysis of photographs has not been extended to specialized histories of the Younghusband Mission, scholarly interest in the implications of colonial photography has grown exponentially over the course of the past twenty years. In particular, the relationship between photography and colonialism in British India is seminally discussed in James R. Ryan's Picturing Empire: Photography and the Visualization of the British Empire (1998). ${ }^{23}$ As a professor of geography at the University of Exeter in Cornwall, Ryan analyzes British photographs taken in India, determining how these images were used to project a system of classification onto many aspects of Indian culture, including racial types, architecture, and landscape. ${ }^{24}$

Histories of British Indian photography have naturally incorporated analyses of exploratory imagery, discussing how tropes resulting from this image-making were directly related to the imperial mind. The catalogue published as an accompaniment to the New York Metropolitan Museum of Art's 2007 exhibition Impressed by Light: British Photographs from Paper

\footnotetext{
${ }^{23}$ James Ryan, Picture Empire: Photography and the Visualization of the British Empire (Chicago: University of Chicago Press, 1998).

${ }^{24}$ James Ryan has written a number of publications on colonial photography since this seminal work, but for economy's sake they will not be discussed at length in this survey. For further reading of Ryan's scholarship, see James R. Ryan, Photography and Exploration (London: Reaktion Books, 2013) and James R. Ryan and Joan Schwartz, ed., Picturing Place: Photography and the Geographical Imagination (London: I.B. Tauris \& Co Ltd, 2003).
} 
Negatives, 1840-186025 includes a number of chapter essays by Roger Taylor, Professor of

Photographic History and Senior Research Fellow at De Montfort University (Leicester). Taylor describes the invention of the callotype in relation to glass-plate photography in great detail, analyzing how the boom in production of varying photographic technology and notions regarding the veracity of subject resulted in an increased demand for photographic documentation of British India and Burma. By incorporating the history of the photographic process itself in his analysis, Taylor implicitly contributes information to the motivations for taking certain types of photographs (studio vs. outdoors, for example) ${ }^{26}$ and using certain types of processes (for example, platinum vs. collodion). ${ }^{27}$

John Falconer, Lead Curator of Prints, Drawings and Photographs at the British Library, has produced a number of books on the development of photography in India during British colonial rule. Of course, these studies primarily incorporate those photographs included in exhibitions held in association with the British Library. In his introductory text for India: Pioneering Photographers, 1850-1900 (2001), Falconer pays particular attention to the development of photographic classification systems developed by the British, evidenced in publications such as The People of India, a volume that is discussed at length in the second chapter of this thesis. Falconer says of this increased interest in photographically documenting racial types:

The comparative linguistic analysis of race, previously one of the main avenues of enquiry, was greatly displaced in these decades by an increasing emphasis on

\footnotetext{
${ }^{25}$ Roger Taylor, Impressed by Light: British Photographs from Paper Negatives, 1840-1860 (New York: The Metropolitan Museum of Art, 2007). Roger Taylor also co-curated the accompanying exhibition with Malcolm Daniel (the Met's Head Curator of the Department of Photographs at the time) and Sarah Greenough (Curator and Head of the Department of Photographs at the National Gallery of Art in Washington).

26 This is discussed in depth in Analysis I in the fourth chapter of this thesis.

27 See also Clark Worswick's The Last Empire: Photography in British India, 1855-1911 (New York: Aperture, 1976). This publication includes a short essay by Clark Worswick on the history of photography in British India, though does not critically analyze the images in great detail. The majority of the book is made up of plates of photographs from the Victorian era. Additionally, see James M. Reilly, Care and Identification of 19th-Century Photographic Prints (Rochester: Eastman Kodak Company, 1986), 10-12 for a brief history of the invention of collodion printing-out papers in the late nineteenth century.
} 
the physical comparison of racial diversity, so much so that by 1865 it was recognized that the appearance, which can so well be preserved and conveyed by photographs was becoming one of the prime avenues of ethnological investigation. ${ }^{28}$

In Points of View: Capturing the $19^{\text {th }}$ Century in Photographs $(2009)^{29}$, Falconer frames the photography generated during imperial expansion within the greater context of Victorian photography, and links the photographic tropes that were developed in different colonies of the British empire. Photography of Tibet is not included in this analysis, but the text discusses how Victorian ideals influenced the insertion of certain implicit messages in the production of photography during this time, which is the basis for much of the analysis in the fourth chapter of this thesis.

In 2002, Eleanor M. Hight, Professor Emerita of Art History at the University of New Hampshire, and Gary D. Sampson, the Chair of Liberal Arts at the Cleveland Institute of Art, published Imag(in)ing Race and Place, a collection of essays that explore the relationship between photography and Western colonialism. ${ }^{30}$ The essays tend to focus solely on the subjects of colonial images, without identifying the provenance of the objects, or the photographic processes that were used to create them. In contrast, Zahid R. Chaudhary's Afterimage of Empire: Photography in Nineteenth-Century India (2012) $)^{31}$ is the most comprehensive material analysis of British India's colonial photography. Specifically, Chaudhary discusses how colonial images have continued to contribute to the contemporary perception of India in the West by tracing the photographs' provenance and present consumption. Again, Tibet is not included in Chaudhary's analysis, but the book is an excellent demonstration of how the materiality of photographs contribute to contemporary historical narratives.

\footnotetext{
${ }^{28}$ John Falconer, India: Pioneering Photographers, 1850-1900 (London: The British Library, 2001), 23.

${ }^{29} \mathrm{John}$ Falconer and Louise Hide, Points of View: Capturing the 19th Century in Photographs (London: The British Library, 2009).

${ }^{30}$ Eleanor M. Hight and Gary D. Sampson, ed., Colonialist Photography: Imag(in)ing Race and Place (London: Routledge, 2004).

31 Zahid R. Chaudhary, Afterimage of Empire: Photography in Nineteenth-Century India (Minneapolis: University of Minnesota Press, 2012).
} 
Ali Behdad, a professor of literature at UCLA who focuses on postcolonial literature and theory, and Luke Gartlan, editor of the quarterly journal History of Photography, published their book Photography's Orientalism: New Essays on Colonial Representation in $2013^{32}$. The book is comprised of essays analyzing photography's instrumental role in the maintenance of Orientalist discourse that is central to Europe's perception of the Middle East. Similarly, UC Berkeley's Martin Jay and Duke University's Sumathi Ramaswamy, both professors of history, published Empires of Vision: A Reader in 2014, ${ }^{33}$ which discusses the roles of photography in the creation and perpetuation of Orientalist perspectives. By incorporating analyses of visual-based historical objects into historical writing, the essays in the text provide useful models of interpretation that can be applied to colonial objects from regions other than India, such as Tibet and the Middle East.

\section{Publications on the Colonial Photography of Tibet}

Though a number of core histories of the Younghusband Mission were outlined earlier in this survey, they do not address the role of the photographs that were taken during the expedition. Like Worswick's The Last Empire (1976), a catalogue of photographs titled Tibet: The Sacred Realm $(1983)^{34}$ published by Aperture is a record of an exhibition curated by Michael Hoffman in the same year. ${ }^{35}$ The 140 photographs are included with descriptive captions, along with an introduction by Tenzin Gyatsho (the Dalai Lama). The photographs are sequenced chronologically by year of creation (from 1880-1950), and the photographers are lauded for "facing inclement weather, the threat of bandits, the objections of the lamas, and countless other

\footnotetext{
32 Ali Behdad and Luke Gartlan, ed., Photography's Orientalism: New Essays on Colonial Representation (Los Angeles: Getty Research Institute, 2013).

${ }_{33}$ Martin Jay and Samathi Ramaswamy, ed., Empires of Vision: A Reader (Durham: Duke University Press, 2014).

${ }^{34}$ Michael E. Hoffman, Tibet: The Sacred Realm (New York: Aperture, 1983).

35 The title of the exhibition is the same as that of the book, and was presented by the Alfred Stieglitz Center at the Philadelphia Museum of Art from March 20-May 22, 1983. The book credits Michael E. Hoffman as the "director," and Martha Chahroudi as the "coordinator."
} 
hardships" all to "distill the essence of Tibet's mystery and its fascination." 36 This catalogue is the first contemporary consolidation of photography taken in Tibet during the Victorian era, but it does not provide critical historical information on British imperialism and its role in the production of the photographs. Additionally, Martha Chabroudi's appendix in the catalogue provides important information on a number of the photographers discussed in the second chapter of this thesis, including Prince Henri D’Orléans, John Claude White, and the studio photographers Johnston \& Hoffman. ${ }^{37}$

A scholar who has critically analyzed the colonial photography of Tibet specifically is Clare E. Harris, former Curator of Photography at the Pitt Rivers Museum and current Professor at Oxford University's School of Anthropology. In 2003, Harris published Seeing Lhasa: British Depictions of the Tibetan Capital, 1936-1947, which she co-edited with Tsering Shakya and released in conjunction with their exhibition of the same name at the Pitt Rivers Museum. ${ }^{38}$ Rather than using the photographs as illustrations for a discussion on the romanticism of Tibet, her essay analyzes the role of the photographs with regard to the imperial goals of colonization. Harris addresses the neglect that images of Tibet have been privy to:

It seems that photography and other kinds of imagery concerning Tibet (including painting and film) have been deemed unworthy of the close reading and context-driven historical analysis which are so essential to the task of literary scholarship. ${ }^{39}$

Harris also discusses the purpose of the accompanying exhibition, which was curated to demonstrate the importance of considering the lived history of colonial photographs and films to

\footnotetext{
${ }^{36}$ Ibid, inner leaf.

37 Detailed information on both Henri D’Orléans and Johnston \& Hoffman is particularly difficult to come by, mainly due to the lack of research that has been done on colonial photography of Tibet. This historical information can be found in archives holding primary documentation, which I was unable to access for research, so Chabroudi's consolidation of this information is especially helpful.

${ }_{38}$ Clare Harris and Tsering Shakya, Seeing Lhasa: British Depictions of the Tibetan Capital, 1936-1947 (Chicago: Serinda Publications, 2003).

39 Ibid, 5.
} 
better understand western perceptions of Tibet. ${ }^{40}$ Although this publication analyzes images dating from 1936 until 1947, the Younghusband Mission occurred from 1903-1904. Regardless, important information on the existence of visual conventions are discussed at length in Harris' writing.

In 2012, almost a decade after the exhibition Seeing Lhasa, Harris published The Museum on the Roof of the World: Art, Politics, and the Representation of Tibet. ${ }^{41}$ A playful jab at Hopkirk's Trespassers on the Roof of the World (1982), Harris discusses in depth the ways that Tibet has been represented in museums around the world since the nineteenth century. Citing British and Chinese collectors and curators as the main proponents of Tibet's romanticization, Harris evaluates the agendas that represent nationalist and colonial aspirations by tracing the conversion of Tibetan culture into a "relic of the past." The origins of photographing Tibetans are specifically outlined in the chapter "Photography and the Politics of Memory." Additionally, the Younghusband Mission is discussed at great length throughout the book, and Harris even incorporates some images taken by John Claude White into her material analysis. She writes on the importance of incorporating photography into analyses of how Tibet is perceived today:

Some may argue that focusing on museums (as well as photography and art) is an indulgence when the difficulties faced by Tibetans in China or in the diaspora are so acute and the stakes are so high. On the contrary, I would argue that analyzing these forms of representation is crucial, precisely because the political dramas are also being played out in the arena of cultural institutions

\footnotetext{
${ }^{40}$ Harris best articulates the purpose of the exhibition in the paragraph: "This essay and the exhibition to which it refers are attempts to bring the issue of vision (and the visual cultures in which it operates) to greater prominence in our misunderstanding of Tibet. In examining the photographic and filmic materials made by the British in Lhasa between 1936, the date of Sir Basil Gould's Mission to Lhasa, and 1947, the year when India gained its independence from Britain, we do not seek to produce a kind of visual ethnography of the Tibetan capital nor to celebrate the British view of the city so highly desirable to colonial cadres in the early twentieth century. Rather, we begin by taking a step back from both the archive and the content of images in order to analyse their production and use in the context of the period in which they were created. Recent research has given great emphasis to the way in which Tibet has been imagined by non-Tibetans, but much of this scholarship has concentrated on textual forms of recording rather than the visual products of encounters between Tibetans and the foreigners who visited them." Ibid, 4-5.

${ }^{41}$ Harris, The Museum on the Roof of the World: Art, Politics, and the Representation of Tibet (Chicago: The University of Chicago Press, 2013).
} 
that are designed to shape public opinion. ${ }^{42}$

The texts described in this section reveal that a critical analysis of Tibet's colonial photography has not been incorporated into the greater consideration of British Indian colonial photography. While photographs of Tibet have been curated into exhibitions, these have usually been ethnographic or celebratory in nature. As the leading scholar in this new discourse, Clare E. Harris has produced a body of work that is crucial for reframing our understanding of the visual culture surrounding Tibet; specifically, the visual culture developed by the British.

This literature survey shows that despite the existence of histories of Tibet, those focusing on the Younghusband Mission do not include considerations of photography's role in the invasion. This is because monographs of the Younghusband Mission only aim to provide a narrative history of events, including photographs as illustrations for textual points. By using the photographs as illustrations, contemporary authors have perpetuated the arbitrary use of colonial photography as documentation of people and events, as seen in the primary texts published by John Claude White and Francis Younghusband. Additionally, the extensive body of scholarship on colonial photography is primarily concerned with photographs taken in British India, and also includes recent investigations into photography of the Middle East and Africa. Though colonial photography has been critically analyzed at great length, the absence of Tibet from these discussions contributes to the narrative of hyper-romanticism that surrounds Tibet today. Clare E. Harris has worked to fill this gap in scholarship, and has generated a body of work that can be applied to colonial images of Tibet specifically. Her research addresses the role of collectors and museums in the presentation of these images. However, without a particular focus on the

\footnotetext{
42 Ibid, 7.
} 
Younghusband Mission, the primary sources, monographs, and biographies that specifically discuss the invasion are still consulted as the most comprehensive sources on the invasion. 


\section{Chapter 2: The Photographic Construction of Tibet}

The late nineteenth and early twentieth centuries were a marked period of intense

colonial expansion by the British Commonwealth. This domination resulted in an unprecedented confrontation of "cultural difference," 43 enforced by the brutal condescension of the colonizers, who maintained power by reifying the dichotomy between their "modernist" culture and the "feudal" lifestyle attributed to the occupied. While scientific advancement was a primary factor in this entitlement, historians also cite the shift towards "a more evangelical religious stance" 44 as an integral component in the development of the Victorian mind in Britain, as it created "a climate in which the New World could assert their assumed superiority and justify this political position scientifically." 45

In the year following the Great Uprising of $1857^{46}$, the British Crown obtained forced sovereignty over the Indian subcontinent. In order to maintain power over the colonized, the British completely reorganised the Indian army, disbanding the units made up of men who were the primary leaders of the Uprising. These rebels were mostly identified as Muslims and Brahmins, so the British formed new regiments made up of alternate identified groups (such as the Sikhs). In order to reorganize the Indian army on such a massive scale, the rigorous collection of data on Indian "races" and/or "types" was carried out. ${ }^{47}$ These prejudicial reports and

\footnotetext{
${ }^{43}$ Elizabeth Edwards, Anthropology and Photography, 1860-1920 (New Haven: Yale University Press, 1994), 5.

${ }^{44}$ Ibid, 6.

${ }^{45}$ Ibid, 6 .

${ }^{46}$ Many sources still refer to the uprising as the "Great Indian Rebellion of 1857," which insinuates that a disservice was carried out against the British by the rebels. This paper will reference the events as the "Great Uprising of 1857 " - a nod to the attempted reclamation of the rebels' native land.

${ }^{47}$ The visual conventions ascribed to Indians predated the invention of photography. "Company paintings," appealing to European employees in British India, illustrated the occupations and castes of Indian people. As these typologies were meant for commercial sale to westerners, emphasis was placed on exoticizing the subjects. This further shaped the western perception of India, and fell in line with the imperial notion of progress gifted to the "primitive" colonizers by the British. When photography was introduced as a new form of image-making, the tropes associated with the company paintings were transmitted to the creation of photographs. For more information on company paintings, see Mildred Archer, Company Paintings: Indian Paintings of the British Period (London: Victoria and Albert Museum, 1992).
} 
documentation resulted in a number of publications outlining the physical, psychological, and cultural characteristics of the inhabitants of British India, and naturally this reportage came to incorporate the use of photography:

In what the British officials saw as an environment of ignorance, superstition, and deceit, this latest product of British ingenuity seemed the very instrument to impress upon active minds once more the difficulty of escaping a superior colonial vigilance. ${ }^{48}$

\section{Ethnographic Imagery}

By the mid-1850s, British India had developed a widely established amateur and professional photographic network. Many Indian and British-run studios were flourishing in Bombay, Calcutta and Madras, and the British template for photographing friends and family had been embraced by the Indian commercial culture, ${ }^{49}$ which served to provide product to the British population that occupied the region. ${ }^{50}$ In addition to these studios, photographers were commissioned by the government to document the colonized landscape and people for official records. Though photographic culture also migrated to surrounding countries, it had not been absorbed by Tibet, which remained isolated from its neighbours due to a harsh climate and geographically treacherous entry passages.

Colonies were often the perfect context for testing the range of new technologies that emerged during the Victorian era, and photography was particularly emblematic of this period of invention, expansion, and science, as it directly contributed to the categorization of land, architecture, and people. This was especially true in British India, where photography had been employed as a method for categorizing the population as early as the 1850s. However, the Great

\footnotetext{
${ }^{48}$ John Tagg, "The Mute Testimony of the Picture: British Paper Photography and India," in Photography's Orientalism: New Essays on Colonial Representation, ed. Ali Behdad and Luke Gartlan (Los Angeles: Getty Research Institute, 2013), 194.

${ }^{49}$ Ibid, 193.

${ }^{50}$ John Falconer, India: Pioneering Photographers, 1850-1900 (London: The British Library, 2001$), 9$.
} 
Uprising of 1857 necessitated a more systematic approach to categorization. Thus, the threevolume photographic publication People of India (1868) was assembled, edited by J. Forbes Watson and John William Kaye. The preface to these volumes briefly addresses the Uprising, chastising the event for "retard[ing] for a time all scientific and artistic operations," primarily the "principles and practice of photography." Specifically, the editors also speak on the role of photography in the preface's introductory paragraph:

During the administration of Lord Canning, from 1856 to 1863, the interest which had been created in Europe by the remarkable development of the Photographic Art, communicated itself to India and originated the desire to turn it to account in the illustration of the topography, architecture, and ethnology of that country. ${ }^{51}$

The volumes are comprised of a number of photographs and didactic texts that are meant to act as definitions and brief explanations of the religious and moral beliefs of the Britishdefined Indian "races." The text consists of brief explanations on the origins of each group, especially for those communities found in India's borderlands, where cultural synthesis was more common. The photographs in the volumes are usually portraits - a male and female "type" of each race [fig. 1] - as well as posed group portraits meant to convey a primary narrative ascribed to the types by the editors. [fig. 2] Figures 1 and 2 are images from the text's section for Bhutanese people, ${ }^{52}$ labeled "Bhootan and the Bhootanese." 53

\footnotetext{
${ }^{51}$ J. Forbes Watson and John William Kaye, ed., "Preface" in The People of India (London: India Museum, 1868), unpaginated.

52 "Bhutanese" is the contemporary English attribution for residents of Bhutan.

${ }^{53}$ Bhutan is a country landlocked between Tibet (to the north) and India (to the south), located on the southern slopes of the eastern Himalayas. The Bhutanese speak a derivative of Tibetic language, and were of great interest to the British because of their apparent similarity to Tibetans, who were less accessible for documentation.
} 


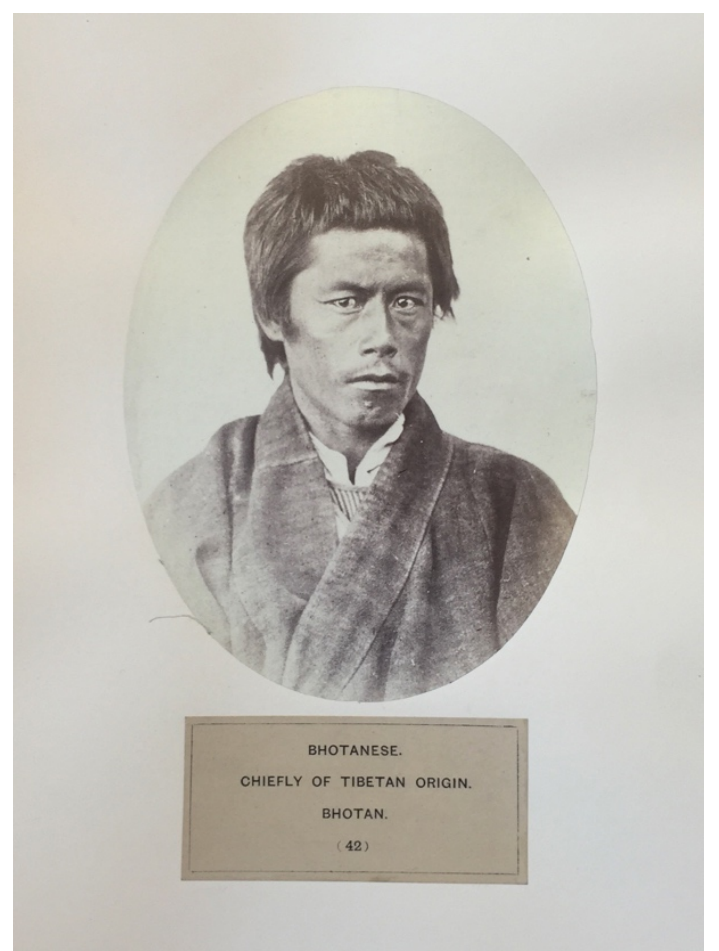

Fig. 1| Unidentified Photographer, Bhotanese Man, 1868, from the section "Bhootan and the Bhootanese" in The People of India (London: India Museum, 1868). Mounted albumen print. Amsterdam, Rijksmuseum.

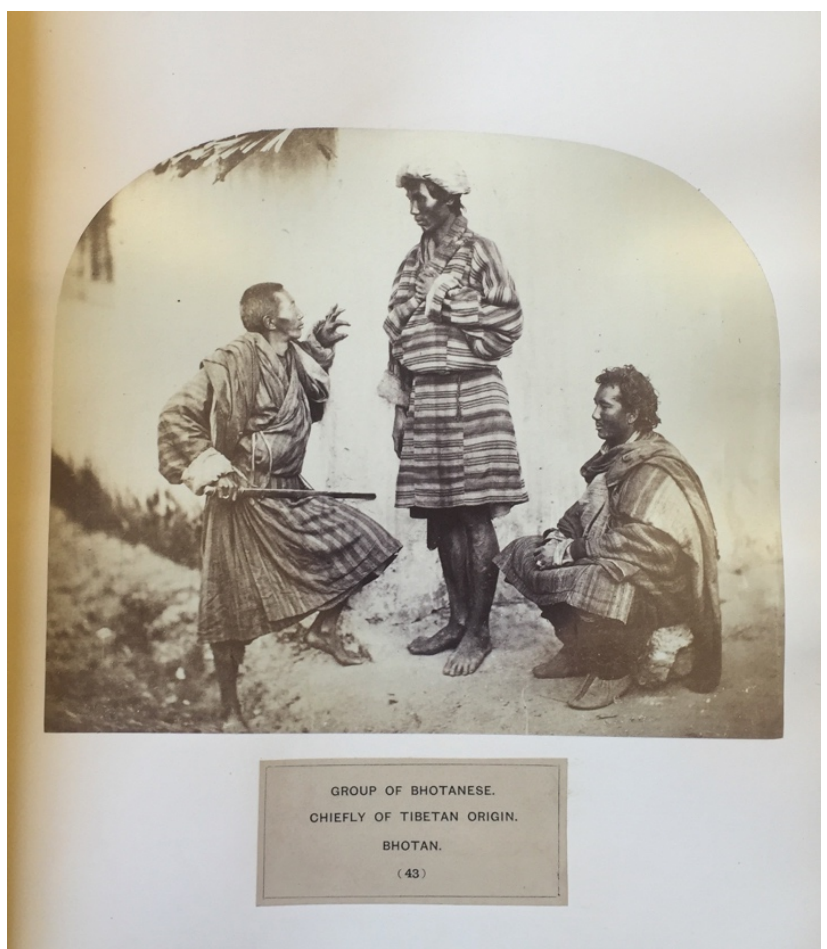

Fig. 2| Unidentified Photographer, Group of Bhotanese, 1868, from the section "Bhootan and the Bhootanese" in The People of India (London: India Museum, 1868). Mounted albumen print. Amsterdam, Rijksmuseum.

Tibet's geographical inaccessibility ensured the country's isolation from colonial powers during the first few decades of British colonial rule over India. However, this inaccessibility perpetuated the British desire to make the region's mystery into something more tangible. Again, the Himalayan foothills were searched for documentation of Tibetans in diasporic regions, such as Assam, Ladakh, Himachal Pradesh and Bengal, ${ }^{54}$ and attempts were first made to describe Tibetans in Volume II of The People of India. Portraits of "Bhotias"-Tibetan immigrants residing in the Himalayan valleys - were included, described with intentionality as "Tibetans by birth and origin." 55 The editors, in their description of the Bhotias, acknowledge the harsh terrain as a main cause for the Tibetans' isolation from British India:

\footnotetext{
${ }^{54}$ Harris, The Museum on the Roof of the World, 82.

55 Watson and John William Kaye, ed., "Tibetan - Bhotias" in The People of India (London: India Museum, 1868), unpaginated.
} 
The inhabitants of the Himalayan valleys are of Tibetan origin; their language and associations differ from those of the people of the plains; to them the name Bhotia, which belongs in strictness to the habitants of Tibet only, is generally applied; the Tibetans proper being, on account of the extreme height, ruggedness, and difficulty of the mountain passes, and the short period during which they remain open, comparatively but little known to the inhabitants of Hindostan. ${ }^{56}$

Generalized descriptions of Tibetan culture are included, composed in the regular anthropological candor of the time, perhaps best exemplified in following paragraph:

The Tibetan language is of the roughest character, abounding in uncouth and, to us, unutterable, combinations of consonants. It is said to have much in common with Chinese. The horrible custom of polyandry prevails, and among most Tibetan tribes, the Ladakhis, for instance, in an especially disgusting form, one wife being the common property of several brothers, of whom the eldest has the right of selecting her. ${ }^{57}$

The persistent allusion to Tibet as a feudal, barbaric society implicitly suggests the cultural superiority of the British compilers of The People of India. The photographs included to illustrate the section on Tibetans perpetuate this notion.

The photographs used to illustrate the section on Tibetans consist of three portraits: two of males [figs. $3 \& 4$ ] and one of a female, [fig. 5] with the general origin descriptors "Tibet" or "Near Lhassa, Tibet" included in the captions. It is interesting to note that in a volume meant to compartmentalize the range of "races" found in India, no mention is made of the possibility of having generalized the idea of what it means to be "Tibetan."

\footnotetext{
56 Ibid, unpaginated.
}

57 Ibid, unpaginated. 


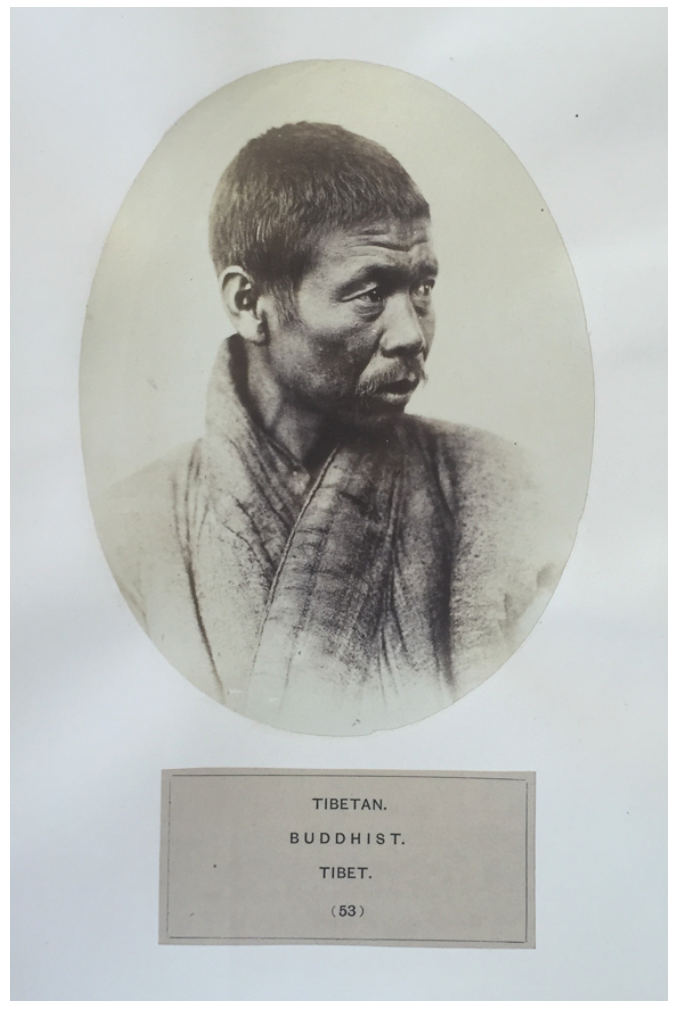

Fig. 3| Unidentified Photographer, Tibetan Man, 1868, from the section "Tibetan-Bhotias" in The People of India (London: India Museum, 1868). Mounted albumen print. Amsterdam, Rijksmuseum.

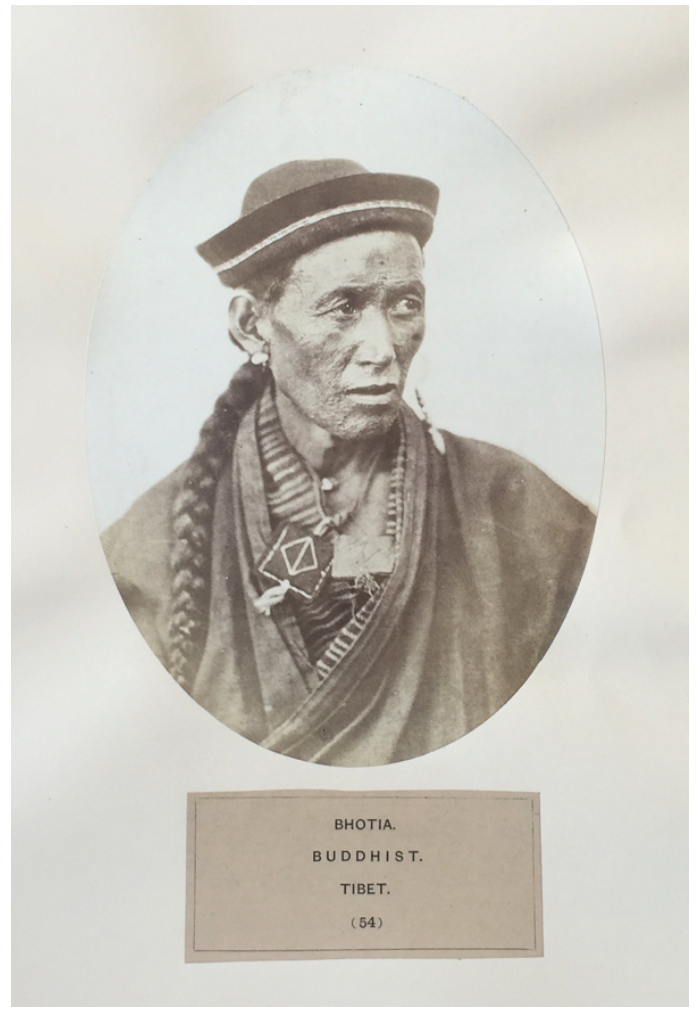

Fig. 4 Unidentified Photographer, Bhotanese Man, 1868, from the section "Tibetan-Bhotias" in The People of India (London: India Museum, 1868). Mounted albumen print. Amsterdam, Rijksmuseum.

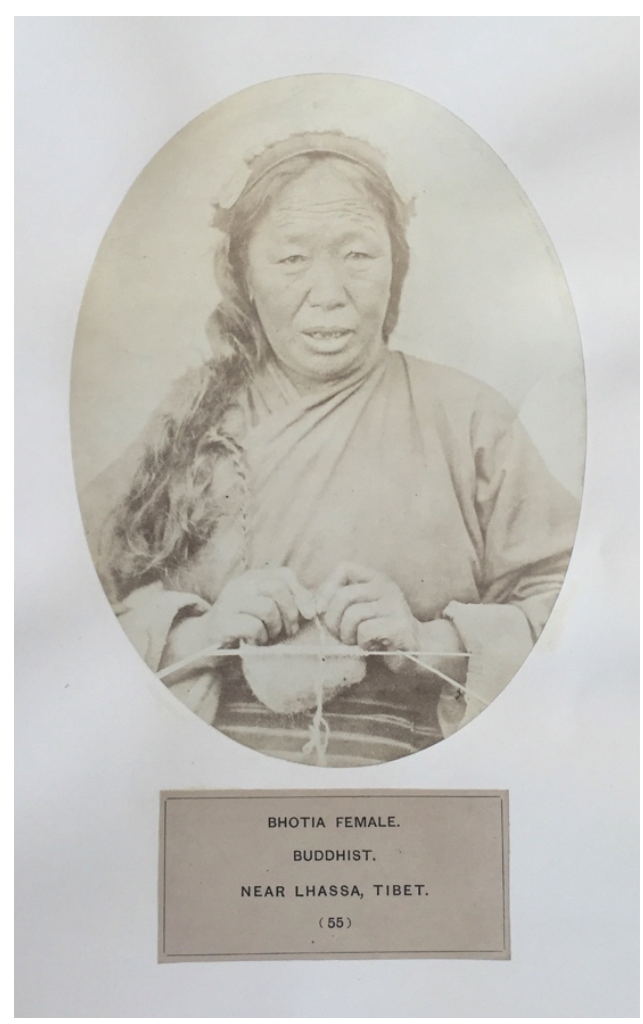

Fig. 5| Unidentified Photographer, Bhotia Female, 1868, from the section "Tibetan-Bhotias" in The People of India (London: India Museum, 1868).

Mounted albumen print. Amsterdam, Rijksmuseum. 


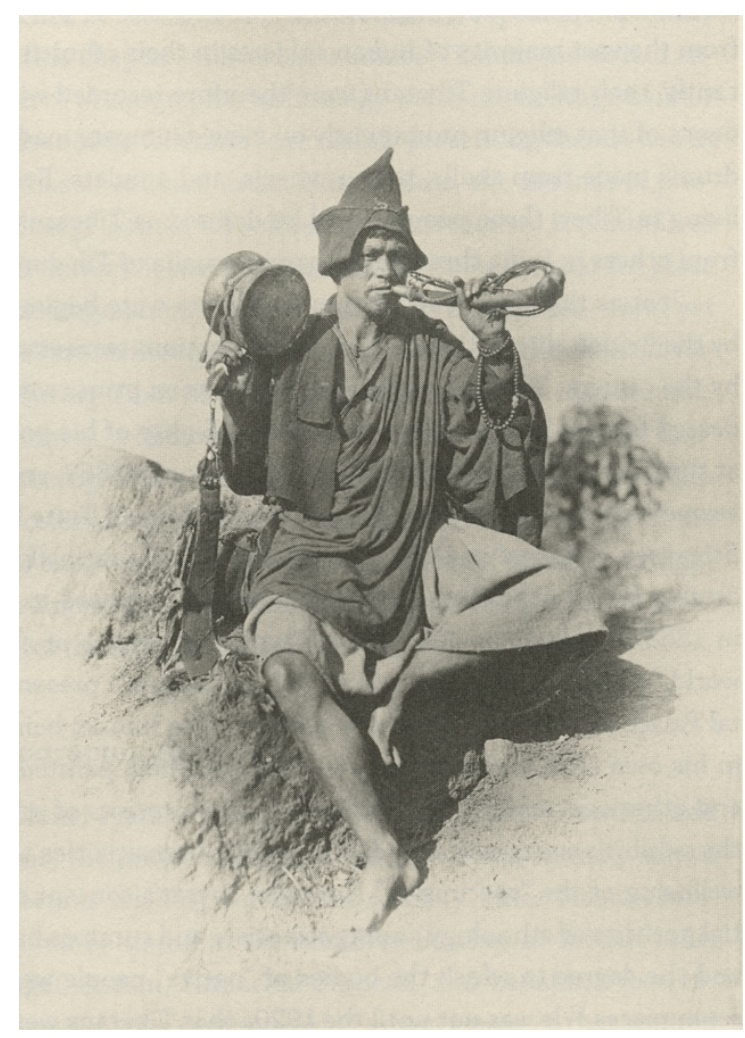

Fig. 6 $\mid$ Benjamin Simpson, A Tibetan Monk in Northeast India, ca. 1860-62. Albumen print. London, Royal Geographical Society.
The main cultural distinction from other

Indian ethnic groups ascribed to Tibetans was their religion, referred to as Lamaism in The People of India, where a few choice rituals are described. ${ }^{58}$ Tibetan religion is a main source for the visual tropes seen in photographs of Tibetans from this time period, as subjects are often shown holding Tibetan Buddhist objects such as prayer wheels, dorjés, instruments made from bone, and amulets. Benjamin Simpson (1831-1923) was a photographer in Northeast India during the 1860s, and as a member of the Indian Medical Service, his primary goal during his visits was to photograph the inhabitants of the far outskirts

of British India. Eighty of Simpson's albumen portraits were exhibited at the International Arts Exhibition in London in 1862, and a number were made into chromolithographs to illustrate Edward Tuite Dalton's Descriptive Ethnology of Bengal (1875). ${ }^{59}$ Simpson's photograph of a "Tibetan monk," captured with a drum and thighbone trumpet, is an example of these posed tropes that were used to classify Tibetans. [fig. 6]

\section{Studio Imagery}

The history of the photographic documentation of Tibetans would be incomplete without mention of Lawrence Waddell, who took it upon himself to document the Tibetan diaspora in

\footnotetext{
58 See J. Forbes Watson and John William Kaye's section titled "Tibetan - Bhotias" in The People of India. After a lengthy discussion on the Tibetans' use of yaks for farming and transportation, the editors include a vague description of Lamaism, "described by Moorecroft as 'a strange mixture of metaphysics, mysticism, morality, juggling and idolatry."'

${ }^{59}$ Harris, Museum on the Roof of the World, 83.
} 
British India for self-proclaimed "anthropological" reasons in the later nineteenth century. His photographic and ethnographic documentation resulted in his publication The Tribes of the Brahmaputra Valley (1900), containing tables of ethnographic and anthropometric data along with his own photographs "organized in the manner recommended by the Royal Anthropological Institute, with full-face and profile views of the individuals he had encountered." ${ }^{60}$ Waddell believed that discrepancies in sample collection were a direct result of using multiple photographers for a single project, and advertised his own project's objectivity by claiming to be its sole photographer.

Regardless of this belief, Waddell commissioned a set of portraits to be made of Tibetan Buddhists in Darjeeling in the early 1890s at one of the photographic studios of Johnston \& Hoffman, who had established a large commercial studio in Calcutta. P.A Johnston and Theodore Hoffman had also opened up smaller studios along the Tibet-Nepal border, where they took an interest in photographing the local inhabitants of the region. ${ }^{61}$ In order to visually classify the portraits as anthropological in nature (rather than the typical theatrical studio images of the time), Waddell ensured that the subjects were placed against a blank backdrop and posed in frontal and profile views. An album of these images, compiled by Waddell himself in the late 1890s, exists under the title Types of Natives of Nepal, Sikhim and Tibet photographed by Messrs Fohnston and Hoffman, Calcutta, with Notes by L.A.W., but was never officially published or exhibited. ${ }^{62}$

\footnotetext{
${ }^{60}$ Ibid, 85.

${ }^{61}$ Michael E. Hoffman, Tibet: The Sacred Realm, Photographs 1880-1950 (New York: Aperture, 1983), 150.

${ }^{62}$ Clare E. Harris suspects that this is because the photographs were taken by studio photographers rather than by official colonial anthropologists, tainting them as objects of aestheticism rather than of science. Harris also explains that Waddell's album was likely rejected due to the tendency of his subjects to stray from "pure types" that were deemed necessary for official anthropological records. Due to the diasporic nature of the individuals that were catalogued, some of the subjects were photographed in attire that was not deemed traditionally "Tibetan," wearing Chinese or European styles acquired at the Darjeeling bazaar. This rejection of Waddell's work evidences the imperial desire to capture the "imagined or ancient," rather than photography's immediate tendency to capture the "actual and present." See Harris, Museum on the Roof of the World, 87-89.
} 


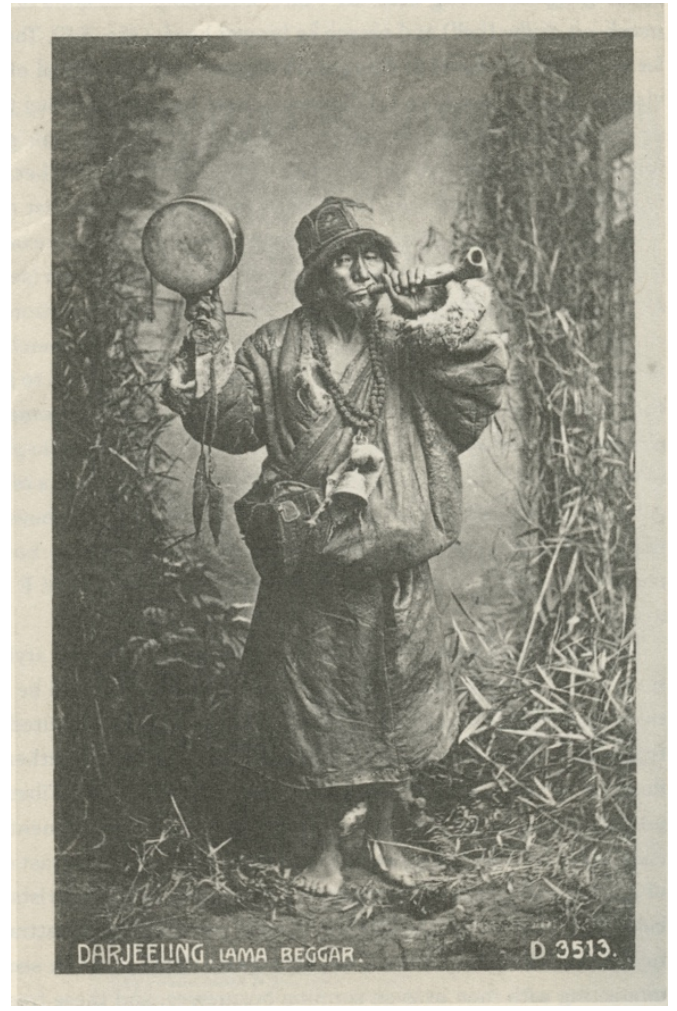

Fig. 7| Late nineteenth century postcard depicting an itinerant Tibetan monk, photographed in India, from Clare E. Harris, The Museum on the Roof of the World (Chicago: Chicago University Press), 94.
Studio photographers also developed a market for souvenir photography of Tibetans. Specifically, Thomas Paar's Darjeeling studio appealed to the tourist population by embracing the invention of the photographic postcard starting in the 1880 s, posing selected locals in highly aestheticized and constructed scenes meant to highlight their being Tibetan. ${ }^{63} \mathrm{~A}$ postcard depicting an itinerant Tibetan monk from the late nineteenth century demonstrates the use of traditional props, and how they were inspired by Simpson's earlier poses. [fig.7] The backdrop of the set also calculatedly references the supposed feudal lifestyle of the subject, though staged inside the studio.

\section{Exploratory Imagery}

Though Tibet was geographically inaccessible for planning a large-scale invasion, a few independent explorers travelled throughout the region before the Younghusband Mission, returning with photographs of the land and its people. Born and educated in England, Prince Henri D’Orléans (French, 1867-1901) was a botanist and geologist with a reputation of "frivolity and indebtedness." 64 However, during an expedition to central Asia (subsidized by his father) in 1889-90, D’Orléans accompanied the French explorer, Gabriel Bonvalot, and the Belgian missionary, Father Dedeken, to an area just north of Lhasa. Upon their arrival, "the Ta Lama and the Chinese Amban met them and advised them, as with all European travelers, to turn

\footnotetext{
${ }^{63}$ For more on the Tibetan picture postcard, refer to Clare Harris' section "The Tibetan Picture Postcard" in Museum on the Roof of the World, 89-96.

${ }^{64}$ Michael E. Hoffman, Tibet: The Sacred Realm, 151.
} 
back." 65 After persistent pleading by the explorers, they were eventually allowed to enter the region, where D’Orléans photographed prolifically, reproducing many of the images in his published account of the journey, De Paris au Tonkin à travers le Thibet inconnu (1892). ${ }^{66} 67$

While these images are not in the portrait-style found in The People of India or mainstream studio photography, there is still evidence of instructed posing in many of the photographs. [figs. $8 \& 9$ ] The main difference between these and the previously outlined poses is that the Tibetan landscape and context are often incorporated into the background of D’Orléans' photographs, since he created the images as an explorer rather than as a professional studio photographer. [fig. $10]$

Bonvalot (D'Orléans' accompanying explorer) also wrote on the expedition in his publication Across Thibet (1892), where he expands on D’Orléans' regular struggle with photography in the region:

February 6. - The light being bad yesterday, it was not till this morning that Prince Henry could photograph this dwelling, and the operation was a more complicated one than might be imagined, for it was necessary to keep clear of the dogs and, if possible, get a portrait of the inhabitants. We have great difficulty in beating off the angry dogs, when a man with a long nose and a very high forehead comes out and calls them off by throwing them bits of dried yak; and while we are getting the apparatus ready, a woman's head peers out from behind the curtain of the tent. She is quite a caricature of a human being, her profile being that of a monkey, just touched up so as to make it slightly resemble a woman. By dint of giving her plenty of raisins, peaches, and apricots, we got her to put out the rest of her body, and, urged on by the old man whose acquaintance we made yesterday, she stands at the door holding her daughter by he hand. ${ }^{68}$

\footnotetext{
65 Ibid.

66 See Clare E. Harris, Museum on the Roof of the World, 280, footnote 33, where the author explains tthat these photographs are thought to be the first photographs of the actual region of Tibet produced by a European.

67 This compilation by D’Orléans is currently housed at the Archives Nationales and Saint-Louis Foundation in Paris, France.

${ }^{68}$ Gabriel Bonvalot, Across Thibet, trans. C. B. Pitman (New York: Cassell Publishing Company, 1892$), 232$.
} 


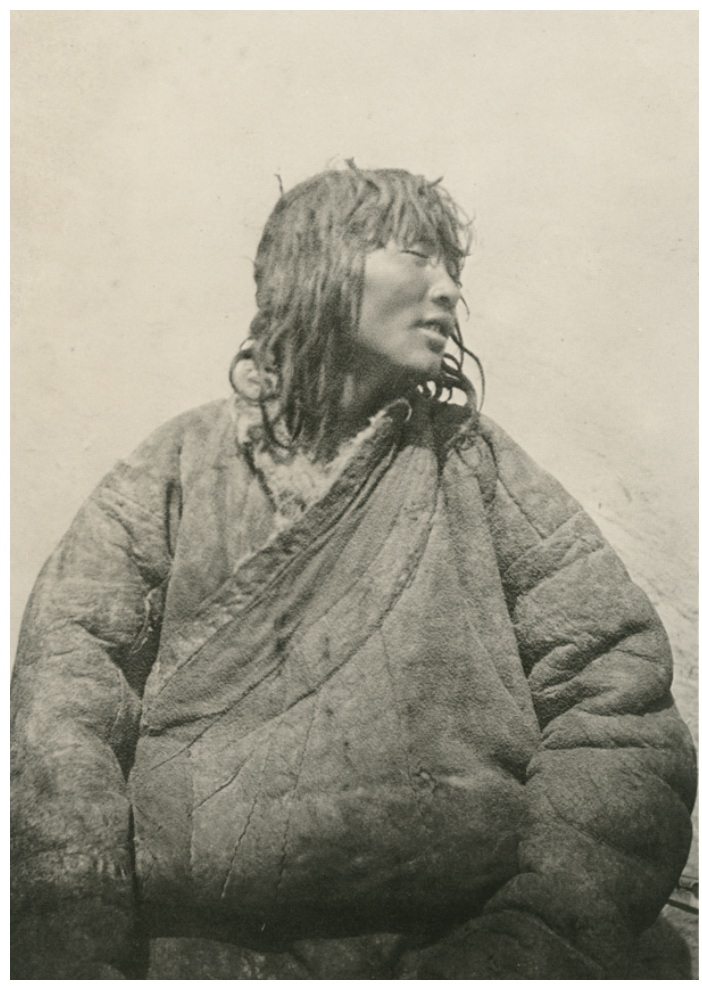

Fig. 8 | Henri D’Orléans, Nomad in sheepskin chuba, Changthang, 1890. Albumen print.

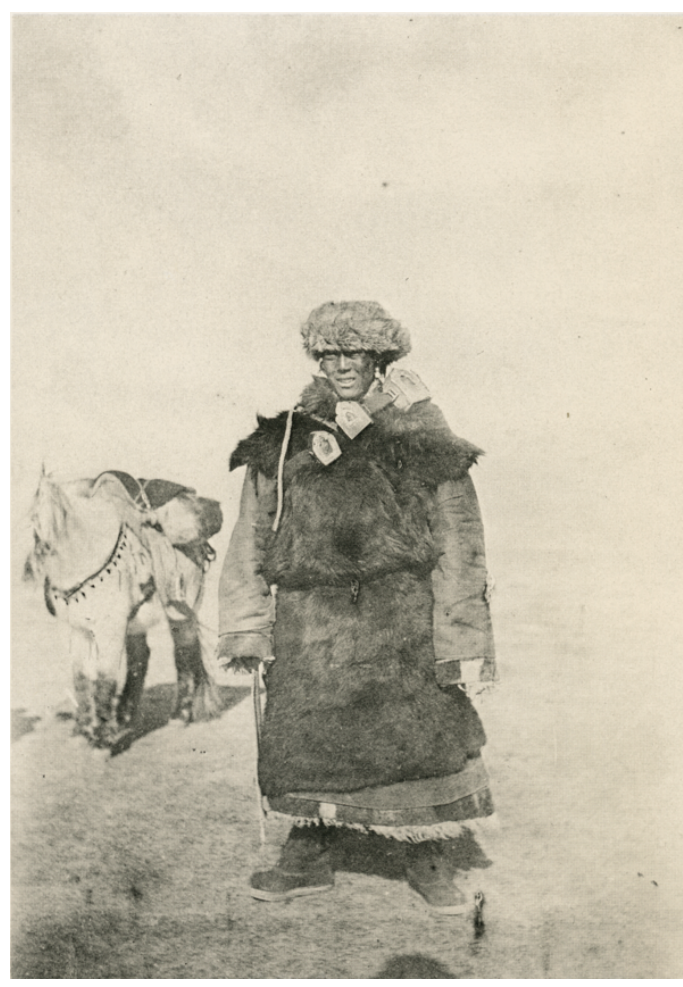

Fig. 10| Henri D’Orléans, Attendant to the Chinese Amban (representative of the Manchu emperor), north of Lhasa, 1890. Albumen print.

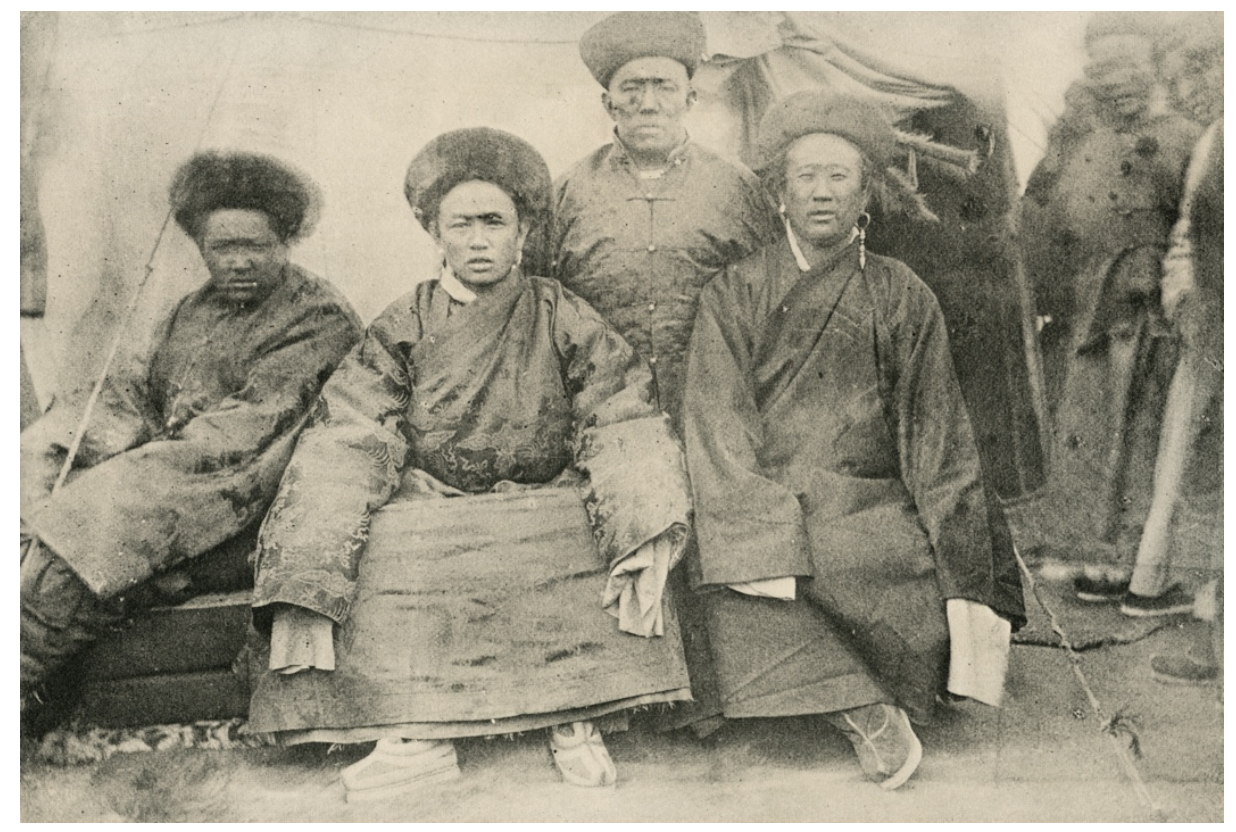

Fig. 9 | Henri D'Orléans, Officials from Lhasa, north of Lhasa, 1890. Albumen print. 
Bonvalot's account of D'Orléans' relationship with his subjects as one of exchange suggests that after a trade, the photographer possessed more instructional agency over his subjects, likely directing the poses he wanted them to perform. The British-raised and educated D'Orléans is therefore another important developer of the colonial way of seeing Tibet and Tibetans, and Bonvalot's description of commodity exchange for photographs sheds light on a relationship between the colonizer and colonized that likely persisted throughout the following decades, specifically in terms of photography of Tibetan subjects.

\section{The Younghusband Mission Photographs}

Aside from the photographs that exist from independent travelers, a larger body of photography was not produced in Tibet until the Younghusband Mission of 1903-04. As described in the second chapter of this thesis, the primary photographer during this invasion was John Claude White, who was appointed second-in-command to Colonel Francis Younghusband to lead the Tibet Frontier Commission. His process of choice was the dry-plate method, using glass plates ranging in size from 12 by $7 \frac{1 / 2}{2}$ to 12 by $9 \frac{1}{2}$ inches. Most of his prints are platinum, though a few gelatin silver prints are known to still exist. ${ }^{69}$

His photographs served many purposes upon his return to British India, most notably as official governmental documentation of the British invasion. His production of large-scale platinum prints afforded the crisp detail that was favourable for inclusion in government records [figs. $11 \& 12$ ]. He published a commercial album of the journey in 1908, titled Tibet and Lhasa, through the studio publishers Johnston \& Hoffman (who had also worked with Waddell). ${ }^{70}$

\footnotetext{
${ }^{69}$ Kurt Meyer and Pamela Deuel Meyer, In the Shadow of the Himalayas: A Photographic Record by Fohn Claude White (Ahmedabad: Mapin Publishing, 2006).

70 See "Lot 224," Bonhams, accessed May 27, 2016, http://www.bonhams.com/auctions/18061/lot/224/ These commercial albums are highly coveted objects for collectors of Victorian photography. Bonhams recently sold one of the compilations for $\mathfrak{£} 38,400$ in 2013.
} 


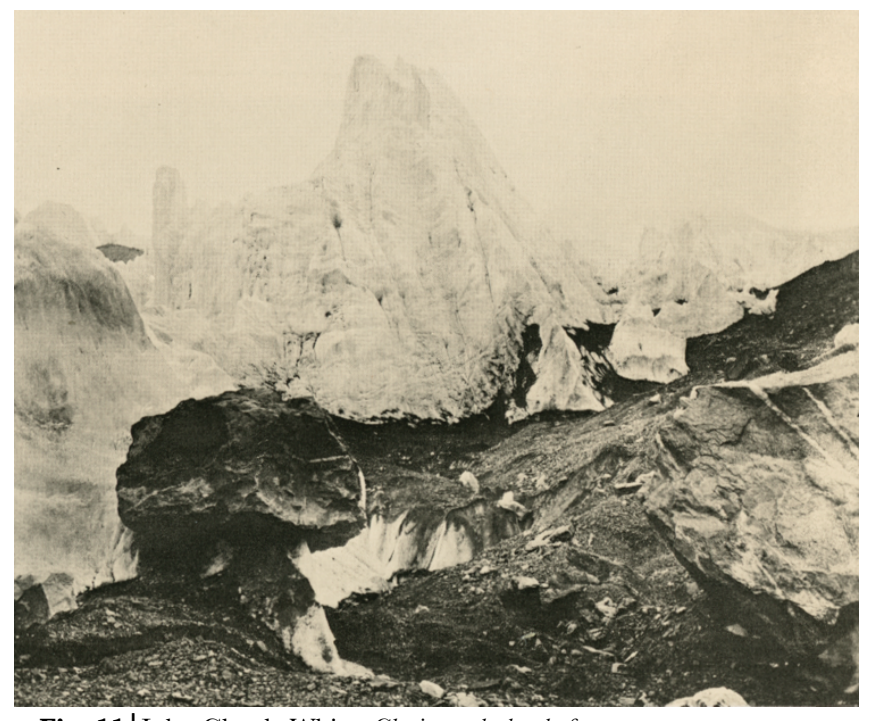

Fig. 11 John Claude White, Glacier at the head of Langpo Valley, Sikkim-Tibet border, 1902. Platinum print.

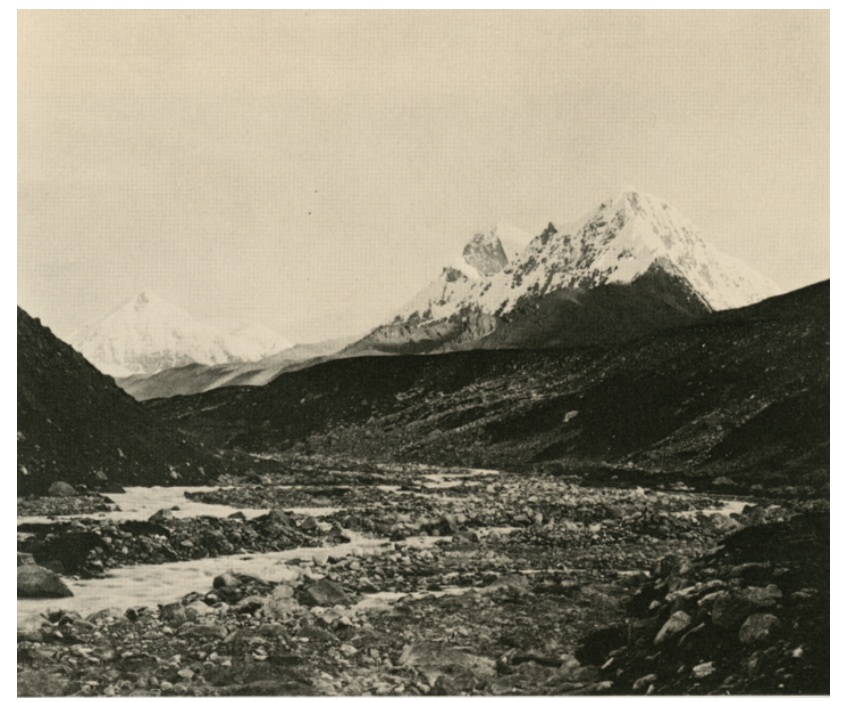

Fig. 12 |John Claude White, View up Langpo River, Sikkim-Tibet border. 1902. Platinum print.

White also wrote an autobiography titled Sikhim $\mathcal{E}$ Bhutan: Twenty-One Years on the North East Frontier, 1887-1908 (1909) upon his return from the Younghusband Mission, in which he included photogravures of his own photographs as illustrations. One of his more famous images depicting the nuns of the Tatsang Monastery [fig. 13] is used in a number of his publications, accompanied by similar general descriptions. In his autobiography he describes the women as "...grossly ignorant, [living] in absolute filth, but they are good-natured and the abbess has a good face." ${ }^{\prime 71}$ In 1916, White published an image of the nuns again in an article he authored for National Geographic titled "World's Strangest Capital" with the following description:72

The nuns, however, seem quite happy and contented, though they are the dirtiest lot of women I have ever seen. Their head covering is made of sheep's wool. After visiting the interior of the building and seeing the refectory we were thankful to be in the open air again." 73

In addition to images of Tibetans, White took many photographs of the landscape and architecture, as well as the camps and posts that were stationed by the British. [fig. 14] The

\footnotetext{
${ }^{71}$ John Claude White, Sikhim and Bhutan: Twenty-One Years on the North-East Frontier, 1887-1908 (Delhi: Vivek Publishing House, 1909), 87.

72 Clare Harris provides more detail on the use of White's image of the Taktsang nuns in Museum on the Roof of the World, 122.

${ }^{73}$ John Claude White, "World’s Strangest Capital," National Geographic 29 (March 1916): 273-95.
} 
clarity and grandiose nature of his work is a by-product of his skill as a large format plate photographer, a practice that was rapidly diminishing in the amateur community at the turn of the century with the introduction of more portable technology and processes.

In his Tibet Album published by Johnston and Hoffman in 1908, White explains "I waited for hours to get a good photograph, and in the end I was successful, although I was nearly frozen in the attempt... The result, however, repaid me for my troubles."'74

Fig. 13 |John Claude White, Nuns at the nunnery of Tatsang. 1903 Platinum print.

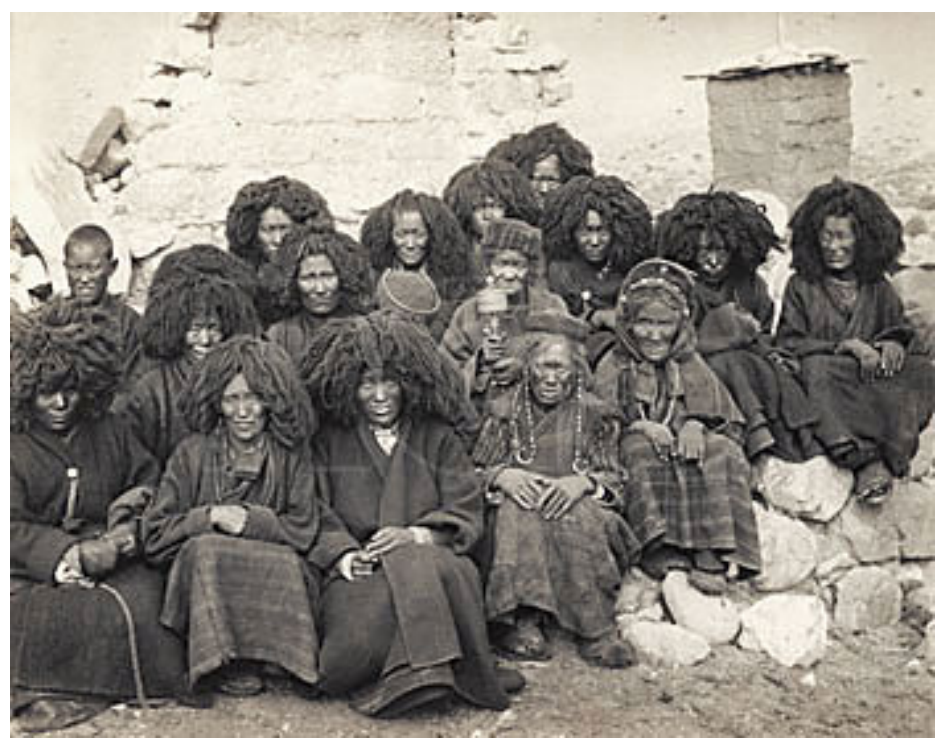

Fig. 14|John Claude White, Kampa Dzong, fortress in southern Tibet, 1903.

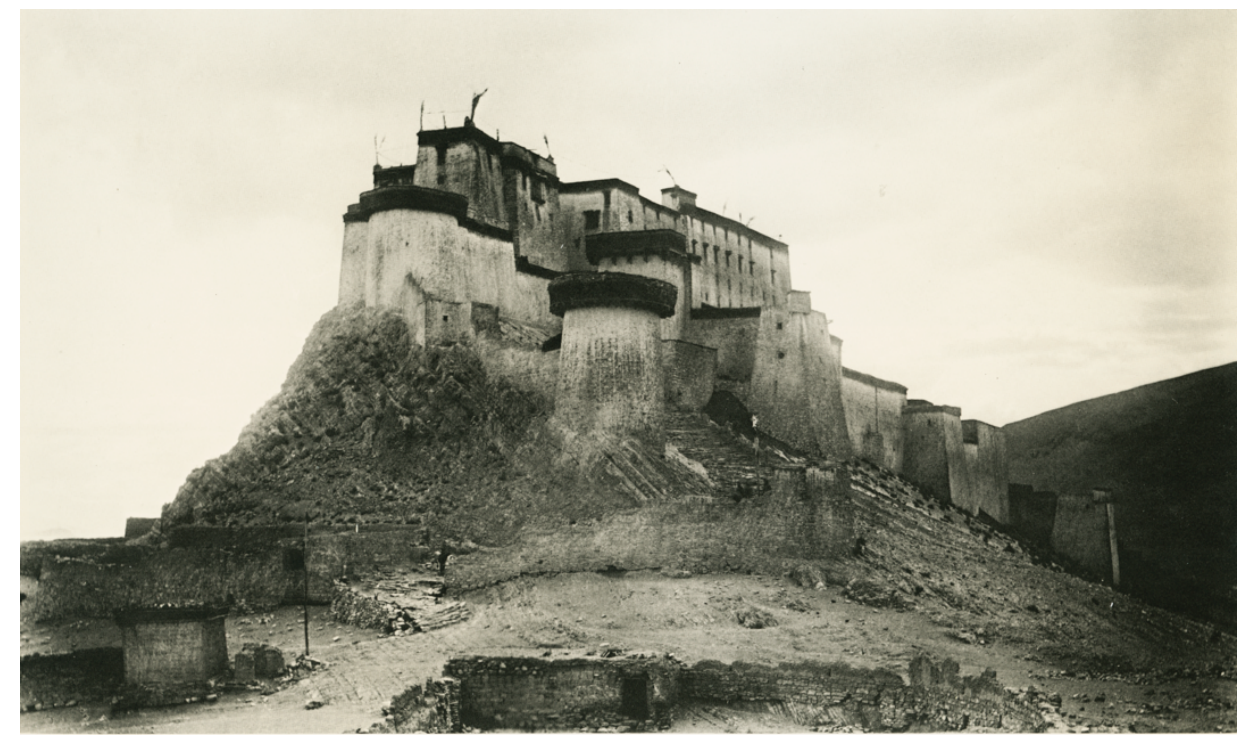

${ }^{74}$ John Claude White, Tibet Album (Calcutta: Johnston \& Hoffman, 1908). 
It is important to note that this outline of the history of photographing Tibet and Tibetans is not conclusive. Rather, it is meant to frame the origins of the patterns and tropes found in the albums analysed in this thesis to demonstrate how the ascribed methods for capturing "pure" Tibetaness were constructed by photographing the diasporic communities of British India prior to the British invasion of Tibet. The photographers of the Younghusband Mission, including large-format imperial photographer John Claude White and candid photographers who favoured more transportable methods, imported these intentional views of Tibet into the country. The similarities between images and their captions across objects and collections demonstrate the prescribed views that were reified as a product of this colonial invasion. 


\section{Ghapter 3: The Gollection}

The primary objects of this analysis are a group of materials related to the Younghusband Mission, currently housed at the Archive of Modern Conflict (AMG) in Toronto. A number of these objects were shipped from the AMC's London office in January 2016 for cataloguing and research specifically related to this thesis. While this project was in its initial stages of development, a range of the $\mathrm{AMC}^{\prime}$ 's photographic objects related to Tibet were considered for analysis, but further research necessitated a focus on the Younghusband Mission exclusively. This focus allowed for a more detailed analysis of how the colonial way of visualizing Tibet was represented in the photographs that were taken during the first large-scale exploration of the country.

The study subjects consist of two photographic albums that were likely constructed after the return of the Younghusband Mission to British India. In total, ninety-six individual photographs are considered in this analysis, although each respective album contains variants of the same images. This means that the ninety-six photographs could also be described as forty-eight images. It is important to describe these objects in detail for better understanding their similarities in subject matter and simultaneous differences in physicality.

\section{Album from Tibet Expedition, 1904}

The first acquisition of this grouping is a cloth-covered album that has been titled Album from Tibet Expedition, 1904 [fig. 15], ${ }^{75}$ and was purchased on December 4, 2012 from Bonhams in Knightsbridge, $\mathrm{UK}$ for $\mathcal{E} 4,750 .{ }^{76}$ The attributed acquisition number for this album is $\mathbf{2 2 6 8 0 .}$ The album's dimensions are $12.5 \times 17 \mathrm{~cm}$, and it contains forty-eight $8 \times 10 \mathrm{~cm}$ collodion

\footnotetext{
75 The album refers to the "Tibet Expedition" rather than the "Younghusband Mission" because the invasion's title only began to reference its commander-in-chief decades after its termination. This is also an indication that the album was likely inscribed with this title closer to 1904, soon after the mission had taken place.

76 “Lot 353," Bonhams, accessed June 28, 2016, https://www.bonhams.com/auctions/19952/lot/353/
} 
prints. ${ }^{77}$ The inside cover has an inscribed title that reads "Snapshots Taken During the Tibet Expedition 1904" in black ink, explaining the title attributed by the AMC [fig. 16]. The subjects found in the album include landscapes, architecture, yaks, mission members, and Tibetan people, and the photographs are window mounted one per page, back to back [fig. 17]. Each photograph is also captioned in pencil on its verso, and these captions match the captions inscribed below each image. In comparison to the other album, the photographs housed in Album from Tibet Expedition, 1904 are quite faded. Having been written in pencil, a number of the captions have also faded.

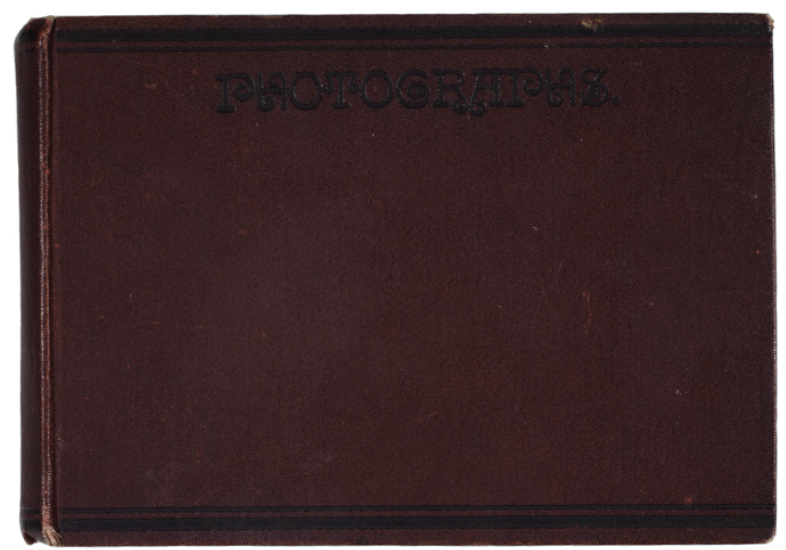

Fig. 15| Front

cover of Album

From Tibet

Expedition, 1904 .

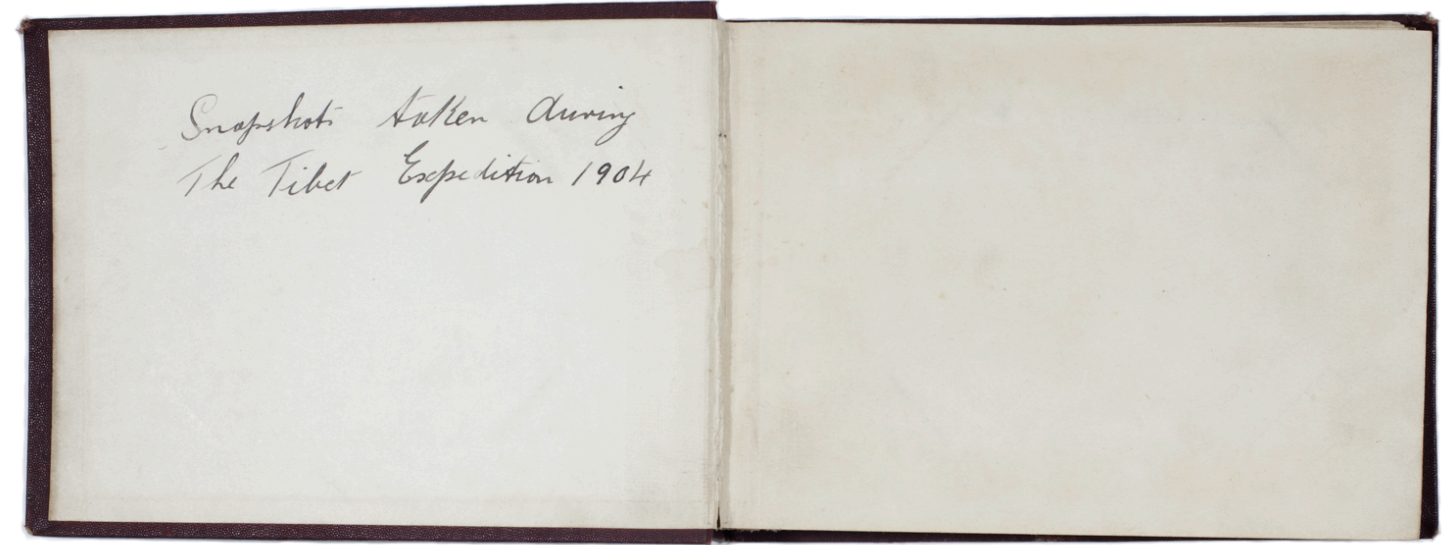

Fig. 16| Inside cover of Album From Tibet Expedition, 1904.

\footnotetext{
${ }^{77}$ Details on the individual prints can be found in the album's corresponding catalogue in Appendix A of this thesis.
} 


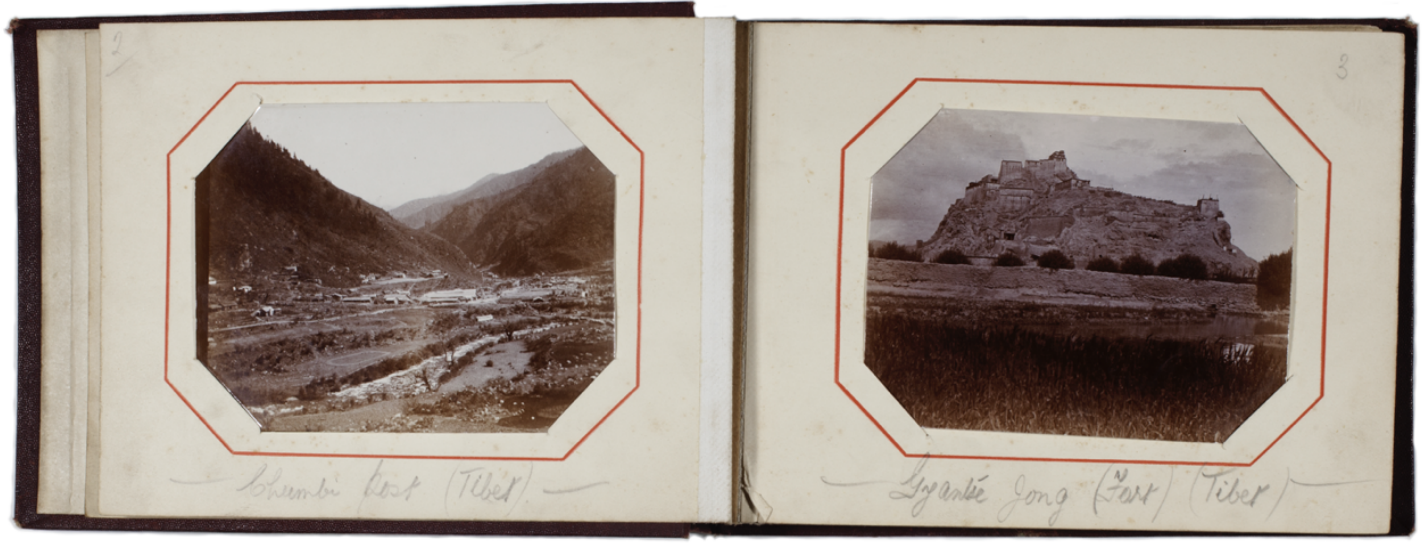

Fig. 17| Example of window mounts used in Album From Tibet Expedition, 1904.

No detailed provenance information on the album could be provided by the AMC, including who originally owned and constructed the object. However, the lot description for the auction of the item describes it as "an album of views in Tibet, presumed to have been compiled by a member of the Field Telegraph, erected to connect Chumbi with Gyantse, during Younghusband's Mission to Tibet, 1904."78 Though "a member of the Field Telegraph" is mentioned in the main description of the object, a small notation in the lot's footnotes also suggests that the album might have belonged to Francis Henry Nichols, author of Through Hidden Shensi (1902). Nichols was not a member of Younghusband's Field Telegraph, so this mixture of information is either incorrect, or (confusingly) suggests that the album, initially compiled by a member of the Field Telegraph, was later owned by Nichols some time after its construction.

78 "Lot 353," Bonhams. 


\section{The Hayman Album}

The AMC acquired the second album on August 20, 2013, almost one year after purchasing the first. The archive has titled the object Album Compiled by Captain William Charles Hayman Relating to the Tibet Expedition Led by Colonel Younghusband, 1904, but for simplicity's sake, it shall be referred to as the Hayman Album throughout this analysis. The cloth cover is more elaborate than the previous album, and reads "HAPPY TIMES" across its front [fig. 18]. Its acquisition number is $\mathbf{2 4 7 9 6}$, and it was purchased from an anonymous dealer. The album also contains forty-eight $8 \times 10 \mathrm{~cm}$ collodion prints, which are mounted two to a page, ranging in mount shape from landscape and portrait ovals to sharp and rounded rectangles [fig. 19]. ${ }^{79}$ Cataloguing these materials resulted in the discovery that the photographs' subject matter was similar to the Album from Tibet Expedition's images. Upon closer inspection, it became apparent that many of the images were identical to those found in the first album, and some images were variations of one another [fig. 20].

William Charles Hayman was Youghusband's aide-de-camp during the mission to Tibet. His direct descendants have sold, through auction houses and dealers, a number of his photographic and Tibetan materials. ${ }^{80}$ It is important to note that the AMC purchased the album attributed to Hayman ten days after another major auction of Hayman's materials ${ }^{81}$, which suggests that the items were dispersed and sold through a number of dealers at around the same time.

\footnotetext{
${ }^{79}$ Details on the individual prints can be found in the album's corresponding catalogue in Appendix B of this thesis. ${ }^{80}$ Mark Allum, "Tibetan Travesty," in Allum's Antiques Almanac 2015: An Annual Compendium of Stories and Facts from the World of Art and Antiques (London: Icon Books Ltd, 2015). Allum details one of the more lucrative auctions of Hayman's materials: the August 10, 2013 sale of an album of over 140 photographs, sold at Henry Aldridge \& Son (Wilshire) for an estimated $f_{10,000}$. The sale also included objects that Hayman looted during the expedition, including a number of religious icons, all of which sold for estimates of between $£ 38,000$ to $£ 65,000$ each.

81 "Photo album reveals a bloody expedition into Tibet," Antiques Trade Gazette, August 19, 2013, accessed June 20, 2016. https://www.antiquestradegazette.com/news/2013/photo-album-reveals-a-bloody-expedition-into-tibet/
} 
Fig. 18 $\mid$ Front cover of the Hayman Album.
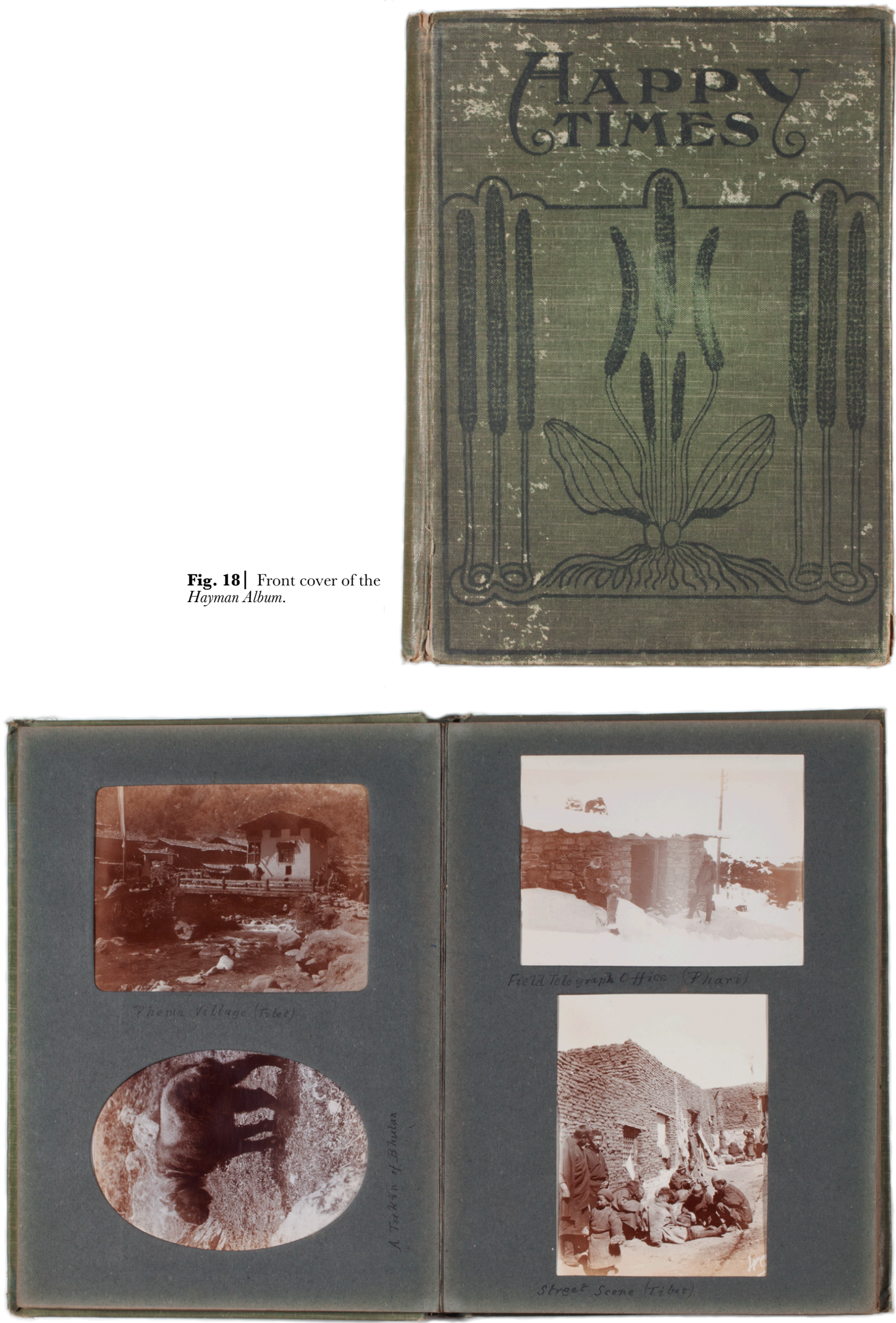

Fig. 19| Inside mount detail of the Hayman Album. 

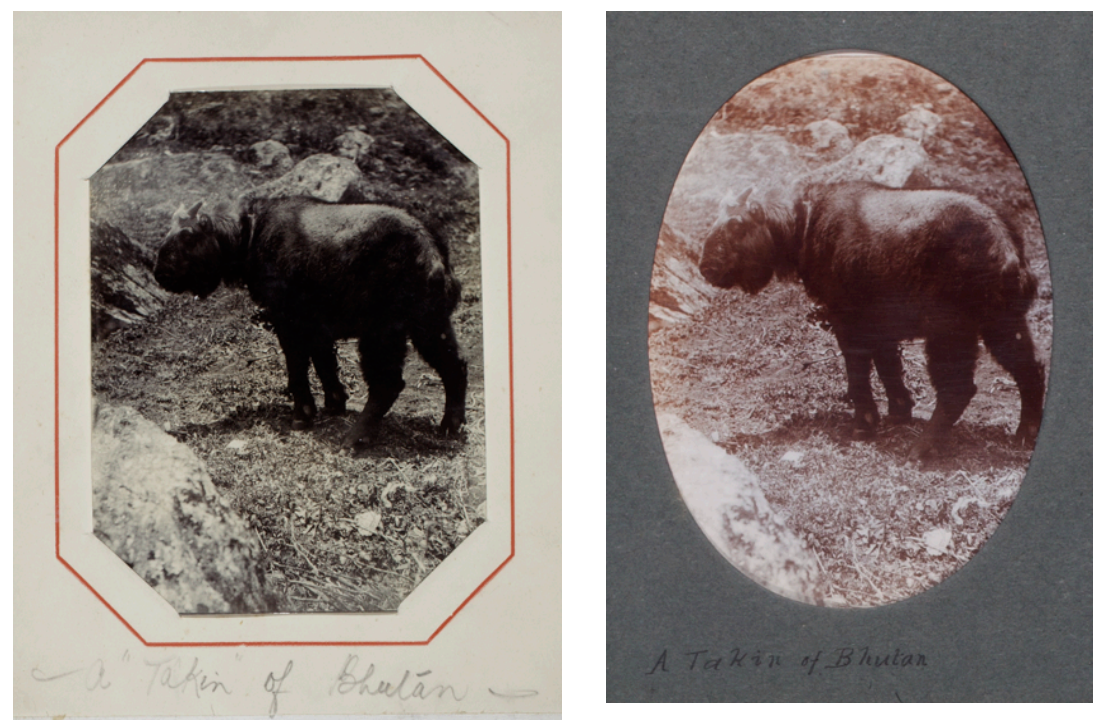

Fig. 20| Left: A Takin of Bhutan, Album From Tibet Expedition, 1904. 22680_1-14. Right: A Takin of Bhutan, Hayman Album. 24796_1-8-3

\section{Methodology \& Initial Observations}

The albums are a unique duo for object-based research because they contain

photographs that were disseminated to the British Field Telegraph staff after their return from the Younghusband Mission. Examples of the tradition of selecting a group of photographs to disseminate to imperial mission members after an invasion is sometimes referenced, but rarely researched in depth, as physical examples of these items are often hard to track and compile because they exist in personal family collections outside of the public sphere. ${ }^{82}$ This thesis is a sampling of the types of research that can be generated from close analysis of these private objects.

\footnotetext{
${ }^{82}$ See Clare E. Harris \& Tsering Shakya, Seeing Lhasa: British Depictions of the Tibetan Capital 1936-1947 (Chicago: Serinda Publications, 2003), 62. In her essay for this exhibition catalogue, Harris briefly mentions that identical albums of mission photographs (along with copies of the Mission Diary) were presented to leading members of the 1936 imperial mission into Lhasa upon their return from the Tibetan capital. Though there is no mention of this tradition having been applied after the Younghusband Mission, it is safe to assume that this souvenir-making likely also occurred after the 1904 invasion.
} 
Though the albums are most likely meant to be souvenirs for members of the Field Telegraph, the photographs do not exclusively document events surrounding the telegraph installation. A number of photographs of Tibetans make up a bulk of the albums' content. The first analysis of this thesis considers how the British way of photographing Tibetans, initially developed before a major expedition breached the Tibetan border, is evidenced by the photographs of Tibetans that were selected for inclusion in the Field Telegraph souvenirs.

The second analysis demonstrates how a number of the photographs are subtle implications of the benefits of the colonial occupation of Tibet. The consistent representation of what Clare Harris refers to as the "dichotomy between feudal past and modernist present" 83 is evidenced by a number of the subjects photographed, including modern bridges, telegraph technology, and the presentation of British forts vs. Tibetan structures.

The fact that the captions inscribed on the album pages match the captions found on the verso of the photographs suggests that the photographs were given to members of the Field Telegraph as loose objects meant to be mounted and captioned by the individuals in an album of their choice. This also explains why the two albums are quite different in physical style, even though they are both meant for personal, domestic viewing.

The third analysis included in this thesis explores in detail the implications of a selected set of images assigned for personal consumption, and how this contributes to the "organised forgetting" of many events that took place during the Younghusband Mission. ${ }^{84}$ While the mission members were aware of the devastating events that resulted in the British occupancy of

\footnotetext{
${ }^{83}$ Harris, The Museum on the Roof of the World, 136.

${ }^{84}$ See Paul Connerton, How Societies Remember (Cambridge: Cambridge University Press, 1989). The process of stateled suppression of undesirable history is discussed in Connerton's book, where he suggests memory is a cultural, rather than individual, experience.
} 
Tibet, the personal albums present a history of the occupancy that can generally be described as positive and non-intrusive.

In addition to these three analyses, historical information meant to contextualize the creation of the objects is included throughout this thesis in an effort to integrate the analyses within the greater context of imperial objectives, specifically in their relation to Tibet. 


\section{Ghapter 4: Analyses}

There are a number of factors that should be addressed to differentiate these personal objects from many of the photographs discussed in the photographic construction of Tibet (Chapter 2). At the time of the Younghusband Mission, amateur photography was becoming a more transportable and affordable form of expeditionary documentation. However, some amateur photographers, such as John Claude White, remained insistent on their preference for large glass plate negatives, as they fit "the ethos of the period, being modern, unambiguous, bright, and capable of rendering meticulous photographic truths". ${ }^{85}$ Because of its association with "artistic" photography, White favoured the platinotype process,${ }^{86}$ which resulted in photographs that were admired for their "delicate tonality." 87

Improvements in photographic technologies in the 1880s meant that mastering the wetplate process was no longer necessary for creating negatives. Gelatin dry-plate negatives were being commercially produced, and were smaller than the larger glass-plate negatives that required on-site knowledge of sensitization. Since these commercially-available negatives were smaller, the cameras sold to facilitate their use were also smaller in size, making the weight of materials lighter. The drawback of transporting heavy glass plates and an abundance of chemicals were especially felt in the extreme climate of Tibet, and so the absence of chemicals and more compact materials were a welcome compromise for amateur expeditionary photographers.

\footnotetext{
${ }^{85}$ Roger Taylor, Impressed by Light: British Photographs from Paper Negatives, 1840-1860 (New York: The Metropolitan Museum of Art, 2007), 69.

86 While platinum prints are exceptionally stable, the cost of platinum experienced massive inflation during the $1880 \mathrm{~s}$ and 1890s, when "the rarity and industrial importance of platinum drove the price so high that the platinoytpe became too costly for general commercial use." See James M. Reilly, Care and Identification of 19th-Century Photographic Prints (Rochester: Eastman Kodak Company, 1986), 8.

87 Ibid, 8.
} 
After creating a collection of negatives during a trip or expedition, amateur photographers were also able to purchase collodion printing-out paper, which allowed them to make contact prints from negatives. This resulted in the creation of prints that were the exact size of the negatives in question. Since the gelatin dry-plate negatives were smaller in size, the prints that resulted from them were also smaller. Thus, a number of dry-plate negatives could be purchased prior to an expedition, shot with a smaller camera, and printed with commercial methods upon the photographer's return to a British base or to England.

Examples of the use of this process are the collodion prints that make up the albums found at the AMC. As has been mentioned, the photographs are similar or identical in both albums because they were disseminated as assembled collections to members of the Field Telegraph after the mission. Though these two albums have emerged from family archives, it is likely that more variants exist in other personal or private collections. Dozens of British men worked for the Field Telegraph in Tibet, and the production of souvenirs for each member necessitated the use of an inexpensive, convenient photographic process. Thus, these photographs taken during the Younghusband Mission are not only the first comprehensive example of colonial photography taken in Tibet; they also act as an example of some more specific uses of gelatin dry-plate negatives and collodion printing-out papers in the production of photography by the British Empire. 


\section{Analysis I: Photographing Tibetans}

As previously mentioned, each of the albums at the AMC contain forty-eight

photographs; nineteen of these either include Tibetans in the image or as the main subject of the image. All photographs are captioned similarly (if not identically), but are not sequenced identically. This analysis uses a selection of these images as the foundation for a commentary on posing, anonymization, the transmission of the Tibetan subject from inside the studio to outdoors, and the construction of candid moments.

\section{Posing}

As was discussed in the photographic construction of Tibet (Chapter 2), visual conventions attributed to Tibetans for photography existed prior to the British exploration of Tibet, and these tropes were used for photographing Tibetans during the Younghusband Mission in 1903-1904. However, the studio conventions of posing are not as immediately evident in photographs of the Mission because they were taken outdoors, and are therefore unconventional.

Aside from our understanding of the contentious relationship between the colonizers and the colonized ${ }^{88}$, there are a number of visual clues that reveal evidence of instruction from the photographer to the subjects. Though the majority of the photographs in the two albums are practically identical in subject and caption, some variations exist, such as the image captioned "Tibetan Women" in both albums. [fig. 21]

\footnotetext{
${ }^{88}$ Recall Henri D’Orléans' method of exchange for convincing his subjects to pose for his camera, not to mention
} the forceful entry of the imperial forces into Tibet. 

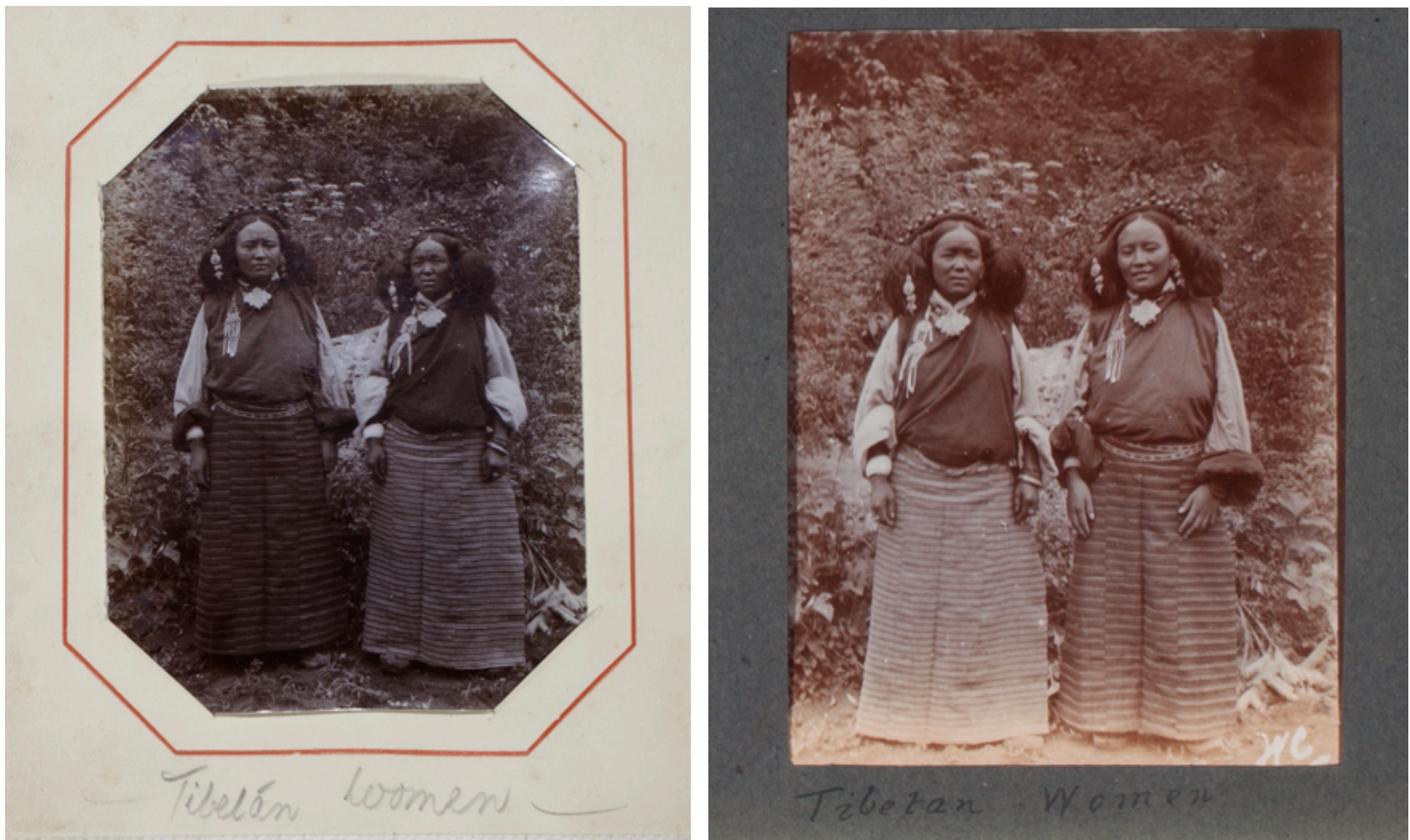

Fig. 21 Left: Tibetan Women, Album From Tibet Expedition, 1904. 22680_1-8. Right: Tibetan Women, Hayman Album.24796_1-5-3

At first glance, the images appear to be identical. However, slight differences indicate that the photographs were created from two different negatives taken during the same sitting. In fact, the women have switched places in each photograph, but their general positioning in front of the same foliage shows that the photographs were taken moments apart. A tuft of flowers that appears in the space between the two women's heads, and the same large-leafed plant just behind the feet of whichever woman has been placed as the right-hand subject, are the main indicators of this identical setting.

These variants provide important information on a number of levels. First, they act as a clear demonstration of a constructed subject - the women were receiving direction from the photographer on where and how to pose themselves. This included the women switching places at some point, revealing the process of creating a range of posed images in order to select an ideal 
image for printing. Since the negatives for these images likely no longer exist, these variants are important evidence of this ideal image construction, ${ }^{89}$ similar to viewing a contact sheet to reveal the working process of a photographer. The image is intended to seem candid, which was a mark of authenticity in exploratory photography of the time. However, analysis of the albums' variants reveals that the women were not photographed candidly; they were instructed to pose.

In the photograph from the Hayman Album, the woman on the right can be seen with a slight smirk, but in the other album's image, the demeanour of both subjects is more serious, specifically in their facial expressions. Not only were the women told where to stand; they were also instructed on how to hold their expressions. This instruction suggests an intended presentation of the women by the photographer, influenced by the tradition of posing of colonized "types" discussed in Chapter 2. Recalling D’Orléans' process of commercial exchange for photographing Tibetan subjects, we could also conclude that requesting these variations in posture came from the photographer, who likely paid the women to pose (or relied on more autocratic methods). ${ }^{90}$

Evidence of posturing is found in another image from the albums, which has been captioned "Tibetan Girl." [fig. 22] Unlike the variants of "Tibetan Women," the respective photographs of the individual girl in both albums are identical. However, like the image of the women, the figure in "Tibetan Girl" is posed in a manner reminiscent of the studio portraiture of Tibetans developed prior to the invasion. The subject has been instructed to lean on some wool skins while posing her hands to reveal her jewelry.

\footnotetext{
${ }^{89}$ Negatives are often the materials that best reveal the working process of a photographer. They can reveal how many images were taken before and after the photograph that was selected for printing. The photographs at the AMG were not accompanied by their negatives, though they might exist in some other private collection. This is why the variants are so important: they are evidence of a larger body of trial images.

90 See Analysis III of this thesis, which discusses the brutality inflicted on the Tibetans by the British when the mission first entered Lhasa.
} 

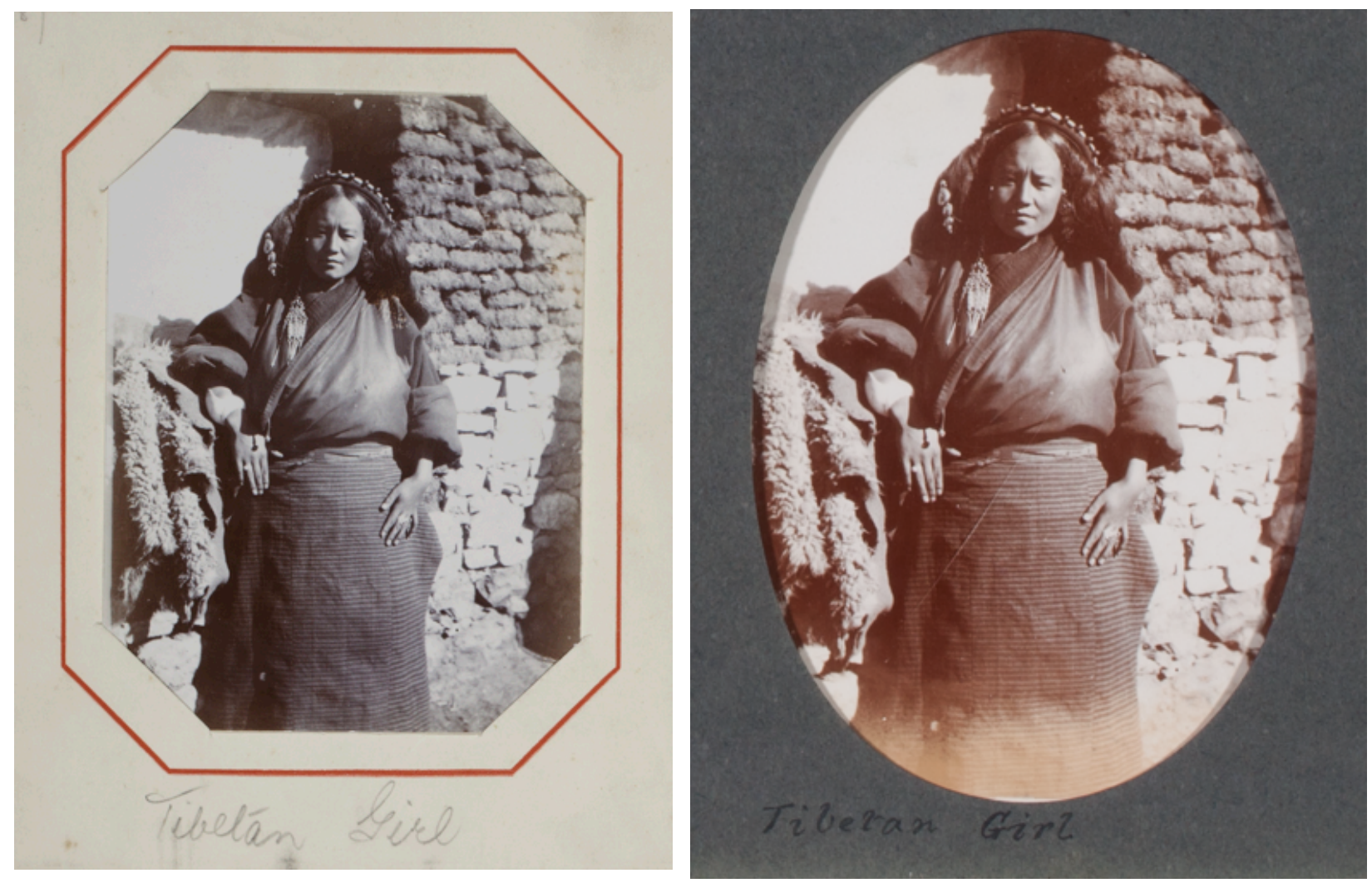

Fig. 22| Left: Tibetan Girl, Album From Tibet Expedition, 1904.22680_1-27. Right: Tibetan Girl Hayman Album. 24796_1-15-3

The similarities in dress between the photographs of the women and the photographs of the individual girl are also an extension of the photographer's posturing of subjects. The ideal subject for a generalized portrait of an "other" necessitated elaborate dress and props that acted as allusions to the subject's class status, religion, and other attributions that could possibly fit within the confines of a photograph. ${ }^{91}$ The women in these images are shown in what was considered to be traditional Tibetan dress, and are wearing a full collection of head and hair ornaments, as well as jewellery. Though labeled generally as "Tibetan Women" and "Tibetan

\footnotetext{
${ }^{91}$ See John Falconer, "To the Ends of the Earth," in Points of View: Capturing the Nineteenth Century in Photographs (London: The British Library, 2009), 50-81. The manifestations of these tropes for Tibet are outlined in Chapter 2 of this thesis, but Falconer demonstrates how this portraiture was also represented in other colonies. See portraits on pages 55, 61-63, 68, and 73 in particular.
} 
Girl," these figures were photographed because of their elaborate, idealized version of the everyday Tibetan figure that would have been encountered by the mission members. This process of subject selection is also revealed in photographs that include women who were not dressed ornately for posing, but who still appear in some group sittings.

In the photograph titled "Group of Tibetans", two women dressed in the photographer's preferred garb appear, who were also seen in the previous portraits. [fig. 23] However, four other women appear in the photograph, dressed less ornately. Why were the more elaborate women selected as the ideal subject for a static Tibetan "type," while the other women were only deemed worthy of inclusion in a group photograph? This selection is an indicator of the tradition of staging the ideal version of "authentic primitiveness" for photographing. ${ }^{92}$
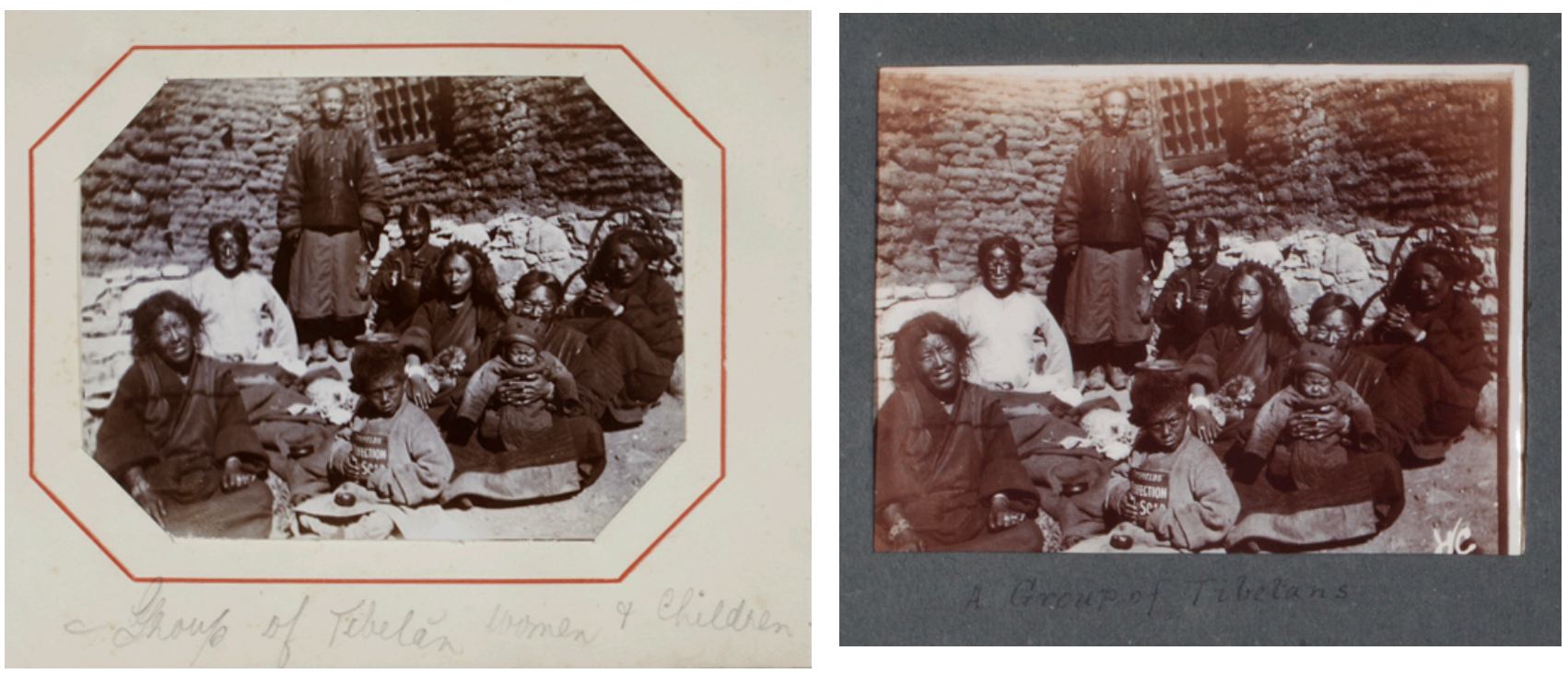

Fig. 23 Left: Group of Tibetan Women + Children, Album From Tibet Expedition, 1904. 22680_1-20 Right: A Group of Tibetans, Hayman Album. 24796_1-10-2.

\footnotetext{
${ }^{92}$ In some cases, the reverse of staging a more elaborately-dressed individual was deemed appropriate, depending on the intention of the photographer. For similar reasons, the more decorated women were selected for inclusion in the albums being analyzed here. This is because they are the individuals who best represent the "authentic primitive" in their natural habitat, as determined by the photographer.
} 
Another pairing in the albums titled "Tibetan Women and Children," [fig. 24] only includes the ornately-dressed individuals in this generalization of "women." Though less ornate women appear in "A Group of Tibetans," they were not deemed aesthetically appropriate to be included in the similarly generalized depiction of "women and children." In fact, each time the descriptor "women," "woman," or "girl" is used in a caption, only the ornately-dressed individuals appear. These women were used as primary subjects because they resulted in photographs that were more appealing for inclusion in the Field Telegraph souvenirs, not because the intent of the photographer was to document Tibetan individuals, as the captions might suggest.
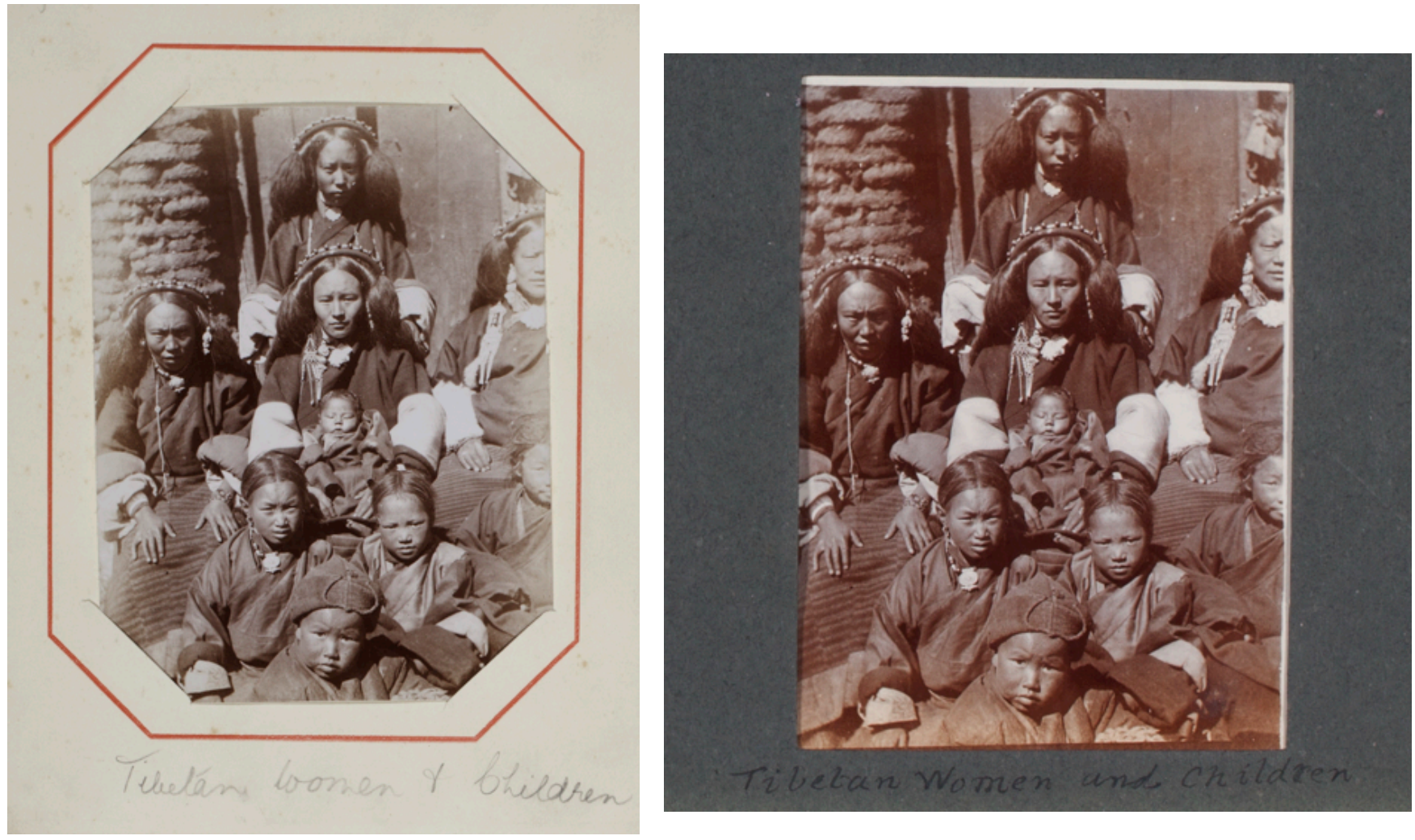

Fig. 24 Left: Tibetan Women + Children, Album From Tibet Expedition, 1904. 22680 1-41. Right: Tibetan Women and Children, Hayman Album. 24796_1-25-3. 
In all of these group variants, the subjects stare directly at the photographer. The image titled "Group of Tibetans" shows all subjects seated except for the one adult male figure, who stands above the rest as a demonstration of his patriarchal role over the group. As evidenced in The Book of India, Tibetan family life was described as barbaric due to the polyamorous traditions of the culture, and the choice of the photographer to request all women and children to sit surrounding the standing man, is meant to capture these familial roles with the absence of descriptive text. ${ }^{93}$

The selection of elaborate types not only manifests itself in the selection of ornatelydressed women. On the other end of the spectrum, those subjects who are often the most devoid of elaborate objects were also selected for posing. ${ }^{94}$ This is found most viscerally in the image captioned "Tibetan Urchins." [fig. 25]

In this instance, "urchin" is meant to identify the figures as homeless street children. The boy in the middle of the group is the only subject who stares directly at the photographer, while the other two boys stare in opposite directions, framing this centre subject. This is perhaps the most obvious example of theatrical posing, reminiscent of the studio images outlined in Chapter 2, where different "characters" were photographed in studios to reveal professions or class status (often tied to and individual's caste). ${ }^{95}$ By posing the children in "Tibetan Urchins," the photographer's aim was not only to illustrate the differences between the ornate women and the

${ }^{93}$ Examples of text attributed to native types can be found on page 20 of this thesis.

${ }^{94}$ On page 6 of the introduction to Afterimage of Empire (Minneapolis: University of Minnesota Press, 2012), Zahid R. Chaudhary states that G. E. Dobson, a contributing photographer for People of India, photographed a woman out of her regular character for the image "Group of Five Young Andamanese Women." While he disclosed in his later writings that he often saw the woman around his community "dressed in white," her accompanying description in People of India classifies her as "destitute of clothes, shaved, and greased with a mixture of olive-coloured mud and fat." Chaudhary refers to this constructed character and posing as a "phantasmagoria of naked flesh, mud-caked faces, and the requisite wooden vessel [a prop indicating the woman's prescribed profession]." This "phantasmagoria" can be extended to this image of "urchins," who are statically posed and labeled with no further explanation.

${ }^{95}$ For more information on ethnographic portraiture of Indian castes, see Stuart Macmillan's thesis, "Colonial Representations of British India: A Description and Analysis of the First Twenty-Four Issues of The Indian Amateur's Photographic Album" (MA diss., Ryerson University, 2011). 
allegedly homeless children. The photograph of the children was included in the souvenir album to highlight the differences between the British colonizers and the non-British colonized. At the request of the photographer, the children have been instructed to look serious and forlorn. This severity implies that the children are unhappy with their circumstances, alluding to the perceived drawbacks of their "feudal" society. However, one might conclude that the boy on the left found it particularly difficult not to giggle during the photographer's instruction, as his serious expression appears to be quite forced.
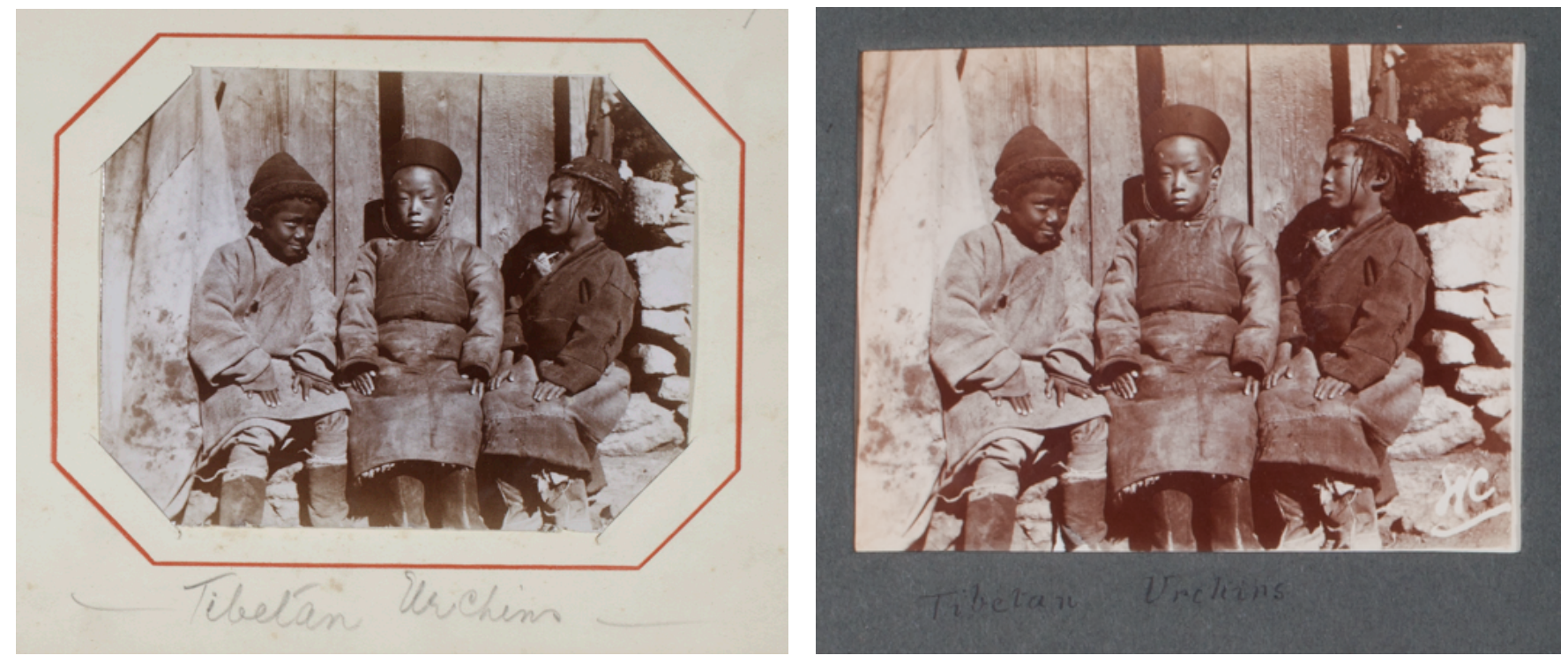

Fig. 25 Left: Tibetan Urchins, Album From Tibet Expedition, 1904. 22680_1-11. Right: Tibetan Urchins, Hayman Album. 24796_1-6-2.

\section{Anonymization: Erasing Identity}

The interaction between photographer and subject outlined thus far implies some sort of communication between parties. As demonstrated with the variants of "Tibetan Women," it is likely that a series of images were taken before selecting an ideal image for printing. These final selections have been placed in the albums and captioned generally, absent of specific details pertaining to the individual subjects. This method of generalizing Tibetan people was informed by the characteristics that were thought to make up the ideal ethnographic photograph, 
conceived of before the image was taken. The photographer, in response to the colonial desire to obtain an image of a standard Tibetan "type," constructed opportunities to create those images that could be quickly identified with general captions. I refer to this non-specific captioning as anonymization.

Focusing on the images of Tibetan people found in the albums is perhaps the simplest way to identify the practice of anonymization. ${ }^{96}$ All Tibetans are captioned with descriptors such as "girl," "women," "group," or "children," and never include the names of the individuals, or any other identifying factors. In fact, it was common for British mission members to photograph people they knew, only to anonymize them in publications to meet the ethnographic standards of the era. ${ }^{97}$

However, captions associated with other types of subjects also reveal the process of generalizing Tibetan individuals. While the majority of captions found in the albums are not particularly detailed, it is clear that more effort has been afforded to some descriptions over others. These more descriptive captions never accompany images whose main subjects are Tibetan people. Table 1 is a list of the most detailed captions and their accompanying photographs.

\footnotetext{
${ }^{96}$ By this I am referring to the previous captions that have been discussed in this chapter, such as "Tibetan Women," "Tibetan Girl," "Tibetan Urchins," etc.

97 This desire to depict a standard, anomymized Tibetan type is especially evidenced in some later photography of Tibet. For example, see Clare E. Harris, "Seeing Lhasa: British Photographic and Filmic Engagement with Tibet 1936-1947," in Seeing Lhasa: British Depictions of the Tibetan Capital, 1936-1947 (Chicago: Serinda Publications, 2003$), 8$. Harris analyzes a 1937 essay in the British film journal Sight and Sound by Spencer Chapman: "Alongside a rear view of a 'nomad woman' (wearing an elaborate headdress), Spencer Chapman includes a portrait of a Tibetan man described as 'An official in ceremonial dress.' This is, in fact, Dasang Damdul Tsarong, a member of the Tibetan government and perhaps the prime interlocutor between the British and Tibetans in the 1930s. Though Spencer Chapman knew him well as the jovial aristocratic host of many a fine party in Lhasa, Tsarong has been 'ethnologised' according to the agenda of image consumption in popular journals. Instead of appearing as an historically significant individual, he has been forced to play the role of a representative Tibetan type... These microhistories enable us to invert the process of anonymisation and generalisation which has so often been the effect of early anthropological photography."
} 
The two captions in Table 1 mentioning "Tibetans" do not focus on the individuals as primary subjects. Rather, the people depicted are secondary to the greater assigned purpose of the image in question. A photograph capturing the "arrival" of the Tashi Lama ${ }^{98}$ provides more specific information on the landscape than is given about the individuals. Similarly, the image titled "Tibetans getting water from Springs" only mentions "Tibetans" to facilitate the narrative of collecting water.

Table 1. Detailed Caption Variants from Both Albums

\begin{tabular}{|c|c|c|c|}
\hline $\begin{array}{c}\text { Album from Tibet } \\
\text { Expedition, } 1904 \\
\text { Identifier }\end{array}$ & Gaption & $\begin{array}{c}\text { Hayman Album } \\
\text { Identifier }\end{array}$ & Gaption \\
\hline $22680 \_1-23$ & $\begin{array}{l}\text { Cantilever Bridge } \\
\text { (Chumbi Valley) }\end{array}$ & 24796_1-4-3 & $\begin{array}{l}\text { Cantilever Bridge } \\
\text { Chumbi }\end{array}$ \\
\hline 22680_1-1-5 & $\begin{array}{l}\text { Phari Village (Tibet) in } \\
\text { winter }\end{array}$ & 24796_1-7-2 & $\begin{array}{l}\text { Phari Village in winter } \\
\text { (looking north) }\end{array}$ \\
\hline 22680_1-15 & $\begin{array}{l}\text { Tent of Tashi Lama } \\
\text { (Tibet) (Leopard skin) }\end{array}$ & 24796_1-7-3 & $\begin{array}{l}\text { Tashi Lama's Tent } \\
\text { (Leopard Skin) }\end{array}$ \\
\hline 22680_1-14 & A Takin of Bhutan & 24796_1-8-3 & A Takin of Bhutan \\
\hline 22680_1-31 & $\begin{array}{l}\text { Tibetans awaiting } \\
\text { Grand Lama's Arrival }\end{array}$ & 24796_1-13-3 & $\begin{array}{l}\text { Tibetans awaiting } \\
\text { Tashi Lama's Arrival } \\
\text { (Chumbi Mtn in } \\
\text { background } 24100 \mathrm{ft} \text { ) }\end{array}$ \\
\hline 22680_1-34 & $\begin{array}{l}\text { Field Telephone at } \\
\text { work (Tibet Exp 1904) }\end{array}$ & 24796_1-16-2 & $\begin{array}{l}\text { Field Telephone at } \\
\text { Work (Tibetan } \\
\text { Expedition 1904) } \\
\end{array}$ \\
\hline 22680_1-33 & $\begin{array}{l}\text { Slaughtered Yaks } \\
\text { (Tibet) }\end{array}$ & 24796_1-20-2 & $\begin{array}{l}\text { Yaks slaughtered for } \\
\text { food for British Troops } \\
\text { (Tibet) }\end{array}$ \\
\hline 22680_1-42 & $\begin{array}{l}\text { Tibetans getting water } \\
\text { from springs }\end{array}$ & 24796_1-25-2 & $\begin{array}{l}\text { Tibetans getting water } \\
\text { from Springs }\end{array}$ \\
\hline 22680_1-45 & $\begin{array}{l}\text { Graves of Officers and } \\
\text { men who fell at } \\
\text { Gyantse (Tibet } \\
\text { Expedition 1904) }\end{array}$ & 24796_1-26-3 & $\begin{array}{l}\text { Graves of officers who } \\
\text { fell during the Tibet } \\
\text { Expedition } 1904\end{array}$ \\
\hline
\end{tabular}

The purpose of highlighting these detailed captions is to shed light on the intention of the caption-maker (who was likely also the photographer) to provide additional details on certain

\footnotetext{
${ }^{98}$ In the Gelug school of Tibetan Buddhism, the Tashi Lama is the highest ranking lama after the Dalai Lama. His mention in the caption is meant to explain the crowd of individuals, rather than to identify him in the photograph, as he is not shown.
} 
scenes in the albums, which was never extended to the captions assigned to Tibetan individuals. This is also evidence that the practice of ascribing generalized Tibetan "types" was used in the creation of these albums, actively following the British tradition of depicting Tibetans specific to ethnographic photography.

\section{Constructing Candid Moments Outside of the Studio}

An analysis of the posed images would not be complete without acknowledgement of their having been taken outdoors. Though British India had developed a prolific network of photographic studios by 1904, this photographic practice had not migrated into Tibet before the invasion. As outlined in the previous analysis, however, the creation of portraits adhering to the era's ethnographic style were still favoured. Without studios, these posed photographs were directed and captured outdoors.

Studios allowed photographers to construct scenes for portraiture in controlled environments, using backdrops and props as identifiers for whichever Indian "type" was being photographed. The influence of these studio scenes is apparent when considering the "natural" settings that the albums' photographer imposed on his subjects outside of a studio. Minimal backdrops were favoured, unless they contributed to the profession or role ascribed to the subject. ${ }^{99}$ These constructed settings are meant to convey a casual scene, and interactions with the environment are only used to assist with the arrangement of the photographer's intended message. While the photograph "Tibetan Women" was taken in front of a backdrop of foliage, ${ }^{100}$ the image "Tibetan girl" incorporates the use of wool skins as an allusion to the subject's domestic practices. The inclusion of this prop is meant to contribute to the purportedly scientific

\footnotetext{
${ }^{99}$ For more information on ethnographic portraiture in British India, see Macmillan, "Colonial Representations of British India," 38-60.

100 Foliage was also a common backdrop used in studio portraiture, where an outdoor scene was reconstructed indoors in a more controlled setting. By posing subjects in front of foliage, the photographers created images that imply an absence or rejection of modernisation by the colonized.
} 
racial truth that ethnographic photography was meant to convey. In other words, the use of skins here is an allusion to the woman's "primitive" possessions.

The constructed scene is most striking in the image "Tibetan Urchins," which has already been discussed in this analysis. The young boys were instructed to sit in the foreground of a wooden wall as a backdrop - a subtle allusion to their minimal feudal lifestyle. As aforementioned, the use of a minimal backdrop was common in studio portraiture of the time, and the barren structure was deemed aesthetically appropriate for posing the children. The positioning of the boys is reminiscent of many poses seen in commercial photography at the time, which aimed to aestheticize the occupation and class of the subjects. ${ }^{101}$ The "occupation" designated to the boys in this case has also been textually assigned: urchins.

\section{* * *}

Though these personal albums are specifically related to the Younghusband Mission's Field Telegraph, the visual conventions ascribed to Tibetans prior to the 1904 invasion were applied in their creation. These generalizations, developed for ethnographic purposes, were used to construct "candid" images of Tibetans. The subjects are further anonymized by the photographs' accompanying captions. By analyzing the photographs within the context of these tropes, the relationship between Tibetans and the British colonizers during the mission is revealed as one of suppression and dehumanization. Providing evidence for these relationships is crucial for reframing the history of the Younghusband Mission in future scholarship on Tibet.

\footnotetext{
101 Recall the scene of the Bhutanese people in The People of India, discussed in Chapter 2. Additionally, studios such as Johnson \& Henderson would often pose subjects in a more theatrical manner so that their photographs appealed to the British population who purchased their commercial photography of Indian "types." The same style is demonstrated in Janet Dewan's The Photographs of Linnaeus Tripe: A Catalogue Raisonné (Toronto: At Gallery of Ontario, 2001) on pages 337-343.
} 


\section{Analysis II: Implicit Superiority}

The predominance of alluding to British superiority in photographs extended beyond ethnographizing individuals in portraits. Civil engineering and modern technological projects were strategically documented in British colonial photography as a means of justifying the British occupation of India. This resulted in a large body of photographic work depicting roads, buildings, modern architectural structures, and European technologies interacting with India's occupied landscape. ${ }^{102}$ Similarly, these implicit references to modernization can also be found in the Field Telegraph souvenirs.

\section{Bridges}

A number of photographs of modern bridges have been included in the albums. The captions identify what types of bridges the photographs depict, as well as their location. [figs. 26\& 27] Based on the Western styles of the structures, it is safe to assume that British engineers built them during the Younghusband Mission, which is also explains their presence in the albums.

The inclusion of these photographs is meant to suggest that prior to the invasion of Tibet, it might have been extremely arduous or even impossible to determine a route over or through the country's terrain. Detailing the specifics of the different types of bridges is meant to demonstrate the range of engineering skills that the British imparted on the region, alluding to the benefits of British colonial modernization. The details included in these captions demonstrate the desire to properly identify anything associated with British productivity, while underrating the structures associated with Tibetan culture.

\footnotetext{
102 John Falconer and Louise Hide claim that Viceroy Lord Curzon (who also ordered the dispatch of the Younghusband Mission from British India) understood the propaganda potential of photography, especially in relation to its worldwide dissemination. In particular, he commissioned many photographs to be taken at the Delhi Durbar of 1902, "a skillfully manipulated and theatrical celebration of British rule." The structures that were built and photographed for the Durbar were meant to embody a message of "western superiority and progress." See John Falconer and Louise Hide, Points of View, 78.
} 

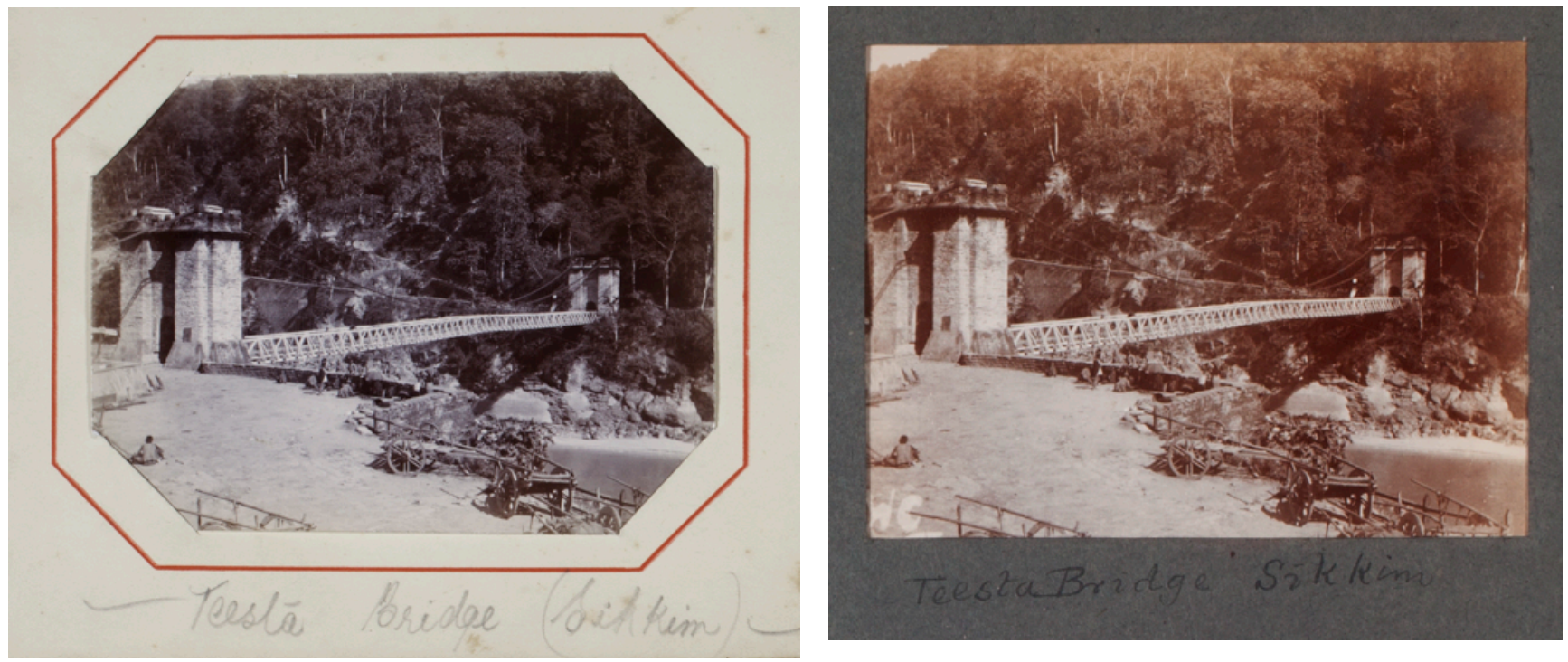

Fig. 26 | Left: Teesta Bridge (Sikkim), Album From Tibet Expedition, 1904. 22680_1-

12. Right: Teesta Bridge Sikkim, Hayman Album. 24796_1-3-2.
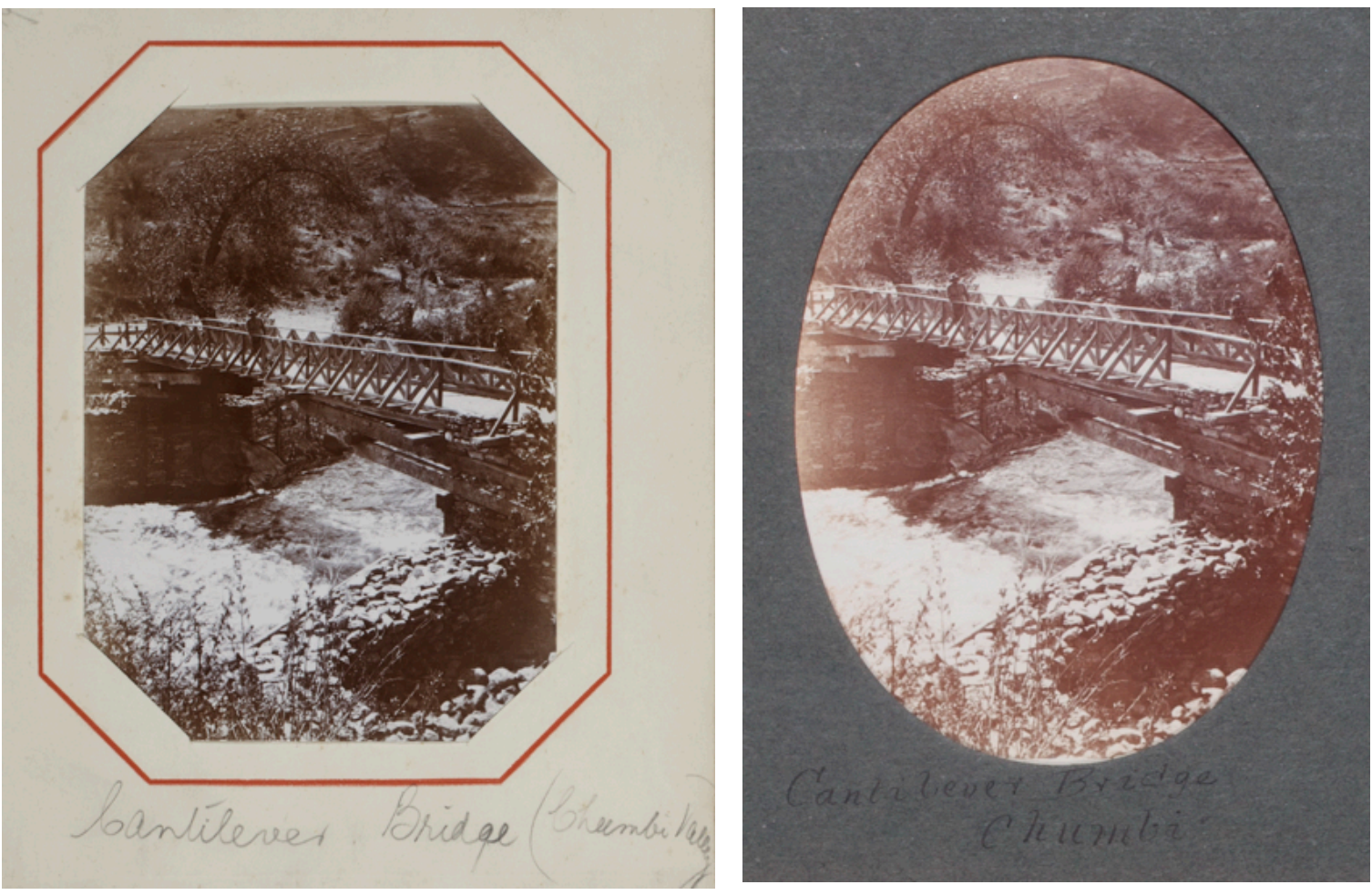

Fig. 27| Left: Cantilever Bridge (Chumbi), Album From Tibet Expedition, 1904. 22680 1-23. Right: Cantilever Bridge, Chumbi, Hayman Album. 24796_1-4-3. 


\section{British Forts vs. Tibetan Structures}

In addition to the albums' photographs of bridges, there are a number of images of

British forts, built for shelter and employment of the mission members in Lhasa. [figs. 28 \& 29]

Descriptors in the captions provide the viewer with the location of the forts, often in addition to

the name of their owner or division. These details reveal a targeted interest in projecting

importance upon the British-made structures. By photographing the buildings individually, the

photographer ensured that the British forts were documented as exclusive subjects and that these

structures are worthy of special attention.
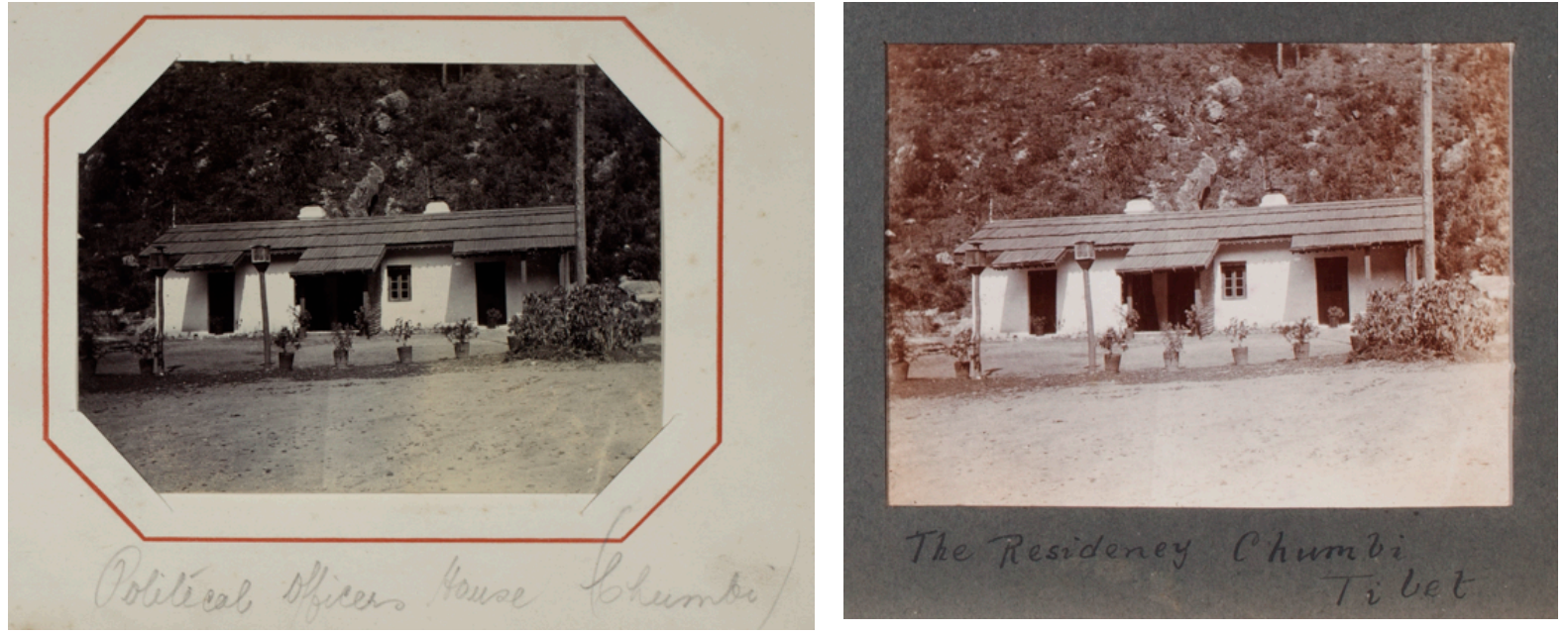

Fig. 28 Left:

Political Officers

House (Chumbi),

Album From Tibet

Expedition, 1904.

22680_1-25 Right:

The Residency,

Chumbi, Tibet,

Hayman Album.

24796 1-3-3.
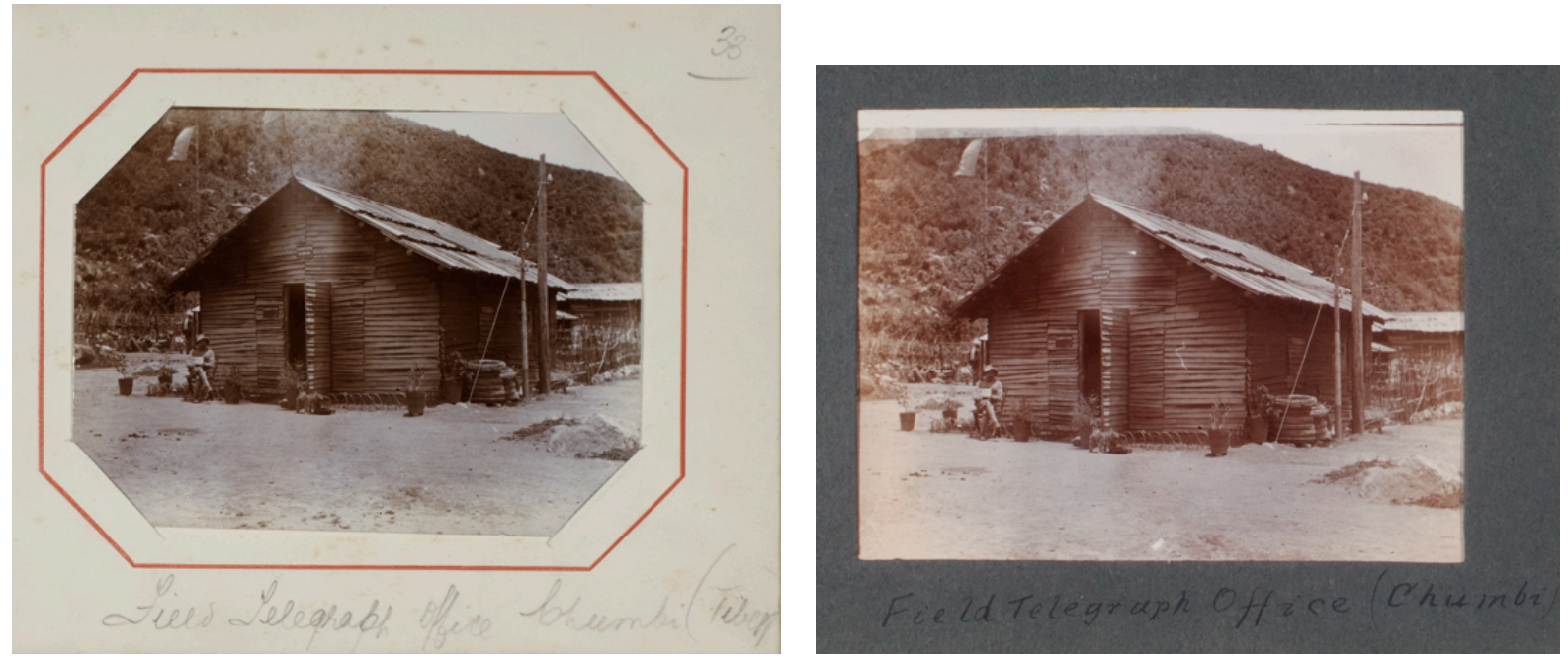

Fig. 29| Left: Field

Telegraph Office,

Chumbi (Tibet),

Album From Tibet

Expedition, 1904.

22680 1-10. Right:

Field Telegraph

Office (Chumbi),

Hayman Album.

24796_1-9-2. 
However, there are a few individual Tibetan structures that are afforded special attention in the albums, but for reasons that are different than the attention paid to the British buildings. The information provided in the caption accompanying a photograph of the Tashi Lama's quarters focuses on the tent's exotic materials: leopard skins. [fig. 30] This tent is one of the only individualized Tibetan structure presented in the albums. The selection of a heavily ornamented tent - that of the Tashi Lama - akin to selecting the most ornamented women for depicting the ideal Tibetan "type" discussed in Analysis I. Unlike the British structures, the tent has not been selected as a demonstration of its architectural superiority. It has been singled out as a lavish and exoticized subject.
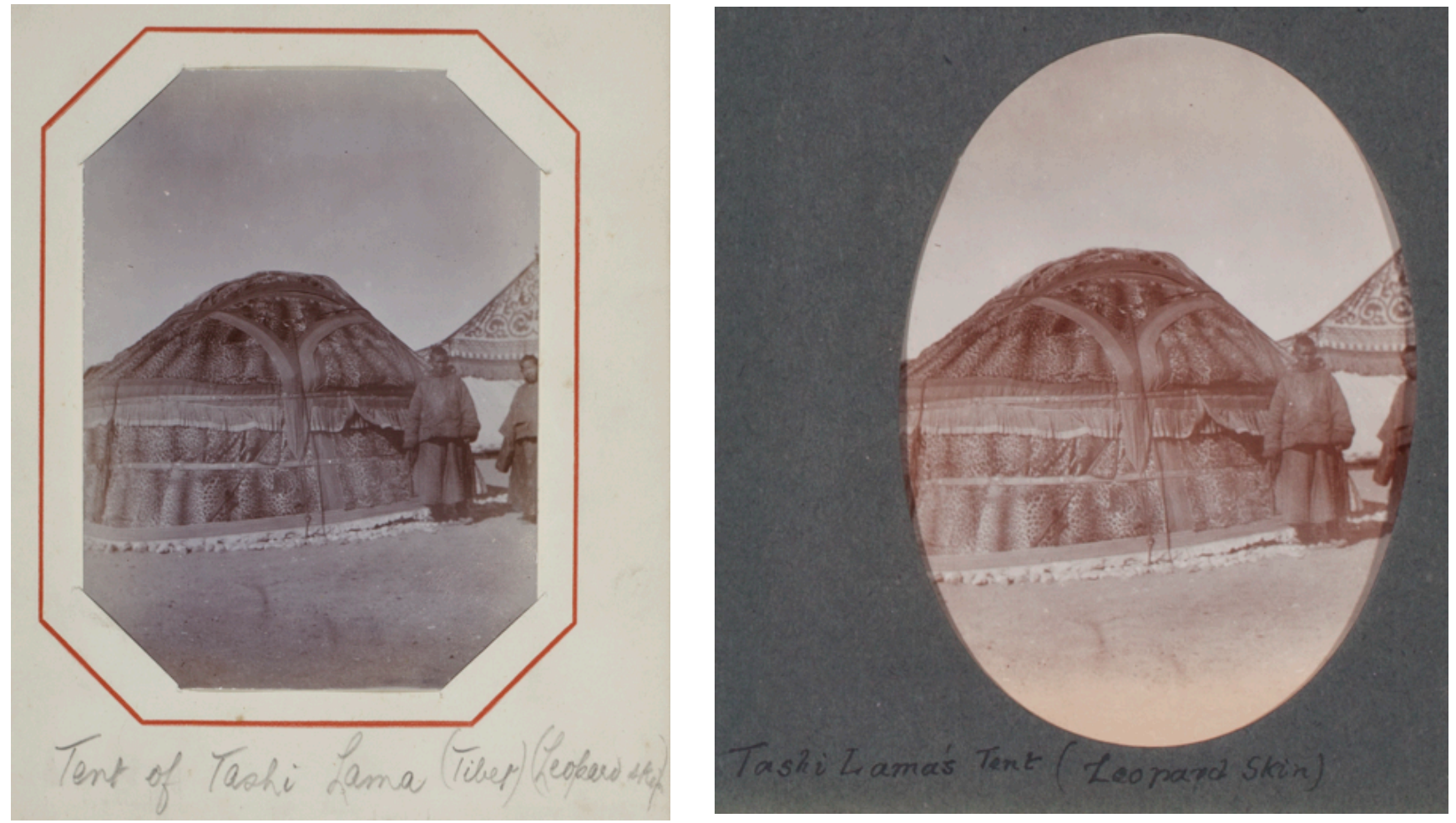

Fig. 30 Left: Tent of Tashi Lama (Tibet) (Leopard skin), Album From Tibet Expedition, 1904. 22680_1-15 Right: Tashi Lama’s Tent (Leopard skin), Hayman Album. 24796_1-7-3. 
This is also seen in the photograph "Tibetan monastery," where only a detail of the structure's stupa ${ }^{103}$ is provided, without any specifications regarding the monastery's name or location. [fig. 31] Like the Tibetan individuals discussed in Analysis I, the stupa and its monastery have been anonymized, included in the albums for exotic purposes.
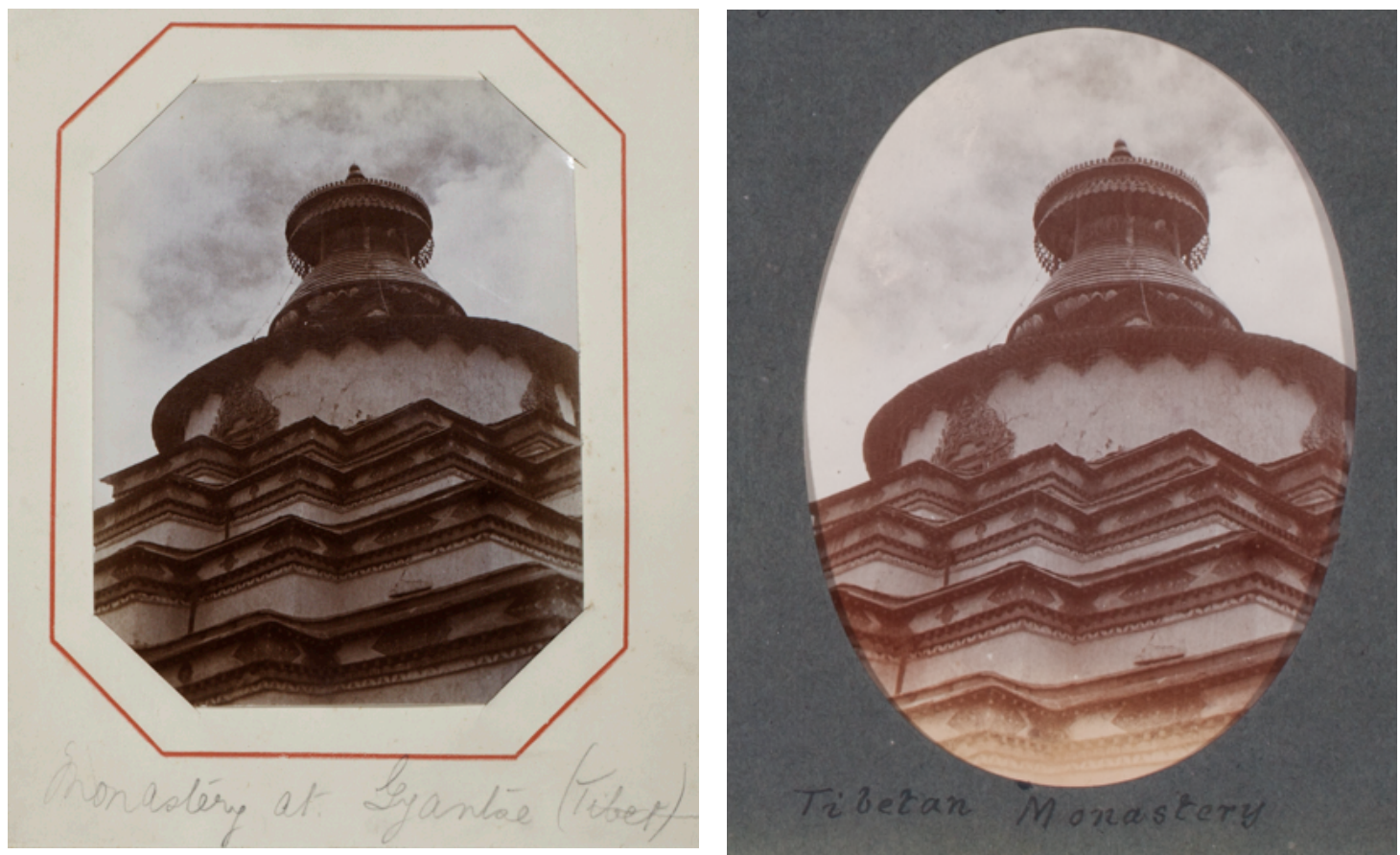

Fig. 31 Left: Monastery at Gyantse (Tibet), Album From Tibet Expedition, 1904. 22680_122. Right: Tibetan Monastery, Hayman Album. 24796_1-11-3.

Despite the selectivity of one Tibetan tent structure, notable attention is also given to the Gyantse Dzong ${ }^{104}$. This grand fortress, which is made up of a number of courtyards, monestarial wings, administrative offices, and monks' quarters, is a structure that was favoured for both textual and photographical documentation by a number of mission members. The Gyantse

\footnotetext{
${ }^{103}$ In Tibetan Buddhism, a stupa is a place of meditation or worship that contains relics within a hemispherical structure. The section of the stupa that was photographed for the Field Telegraph souvenirs is the pointed area on top of the hemisphere.

104 "Jong," used in the captions, was the English phoneticization ascribed to the Tibetan loosely to "fort."
} 
Dzong acted as a main landmark for the British during the Younghusband Mission, and is frequently mentioned in a number of the monographs outlined in Chapter 1 of this thesis.

Any recognition of the $d z o n g$ 's cultural importance is questionable when considering the inclusion of the photograph titled "Ruins of Phari Jong" in the albums. [fig. 32] This image, depicting the ruins of another ancient $d z$ ong, shows a number of British men laying across various points of the crumbled structure. This suggests that the British framed the sites as having less to do with Tibetan cultural and religious importance, and more to do with their depiction of crumbling landmarks as signs of uselessness for themselves, the colonizers.
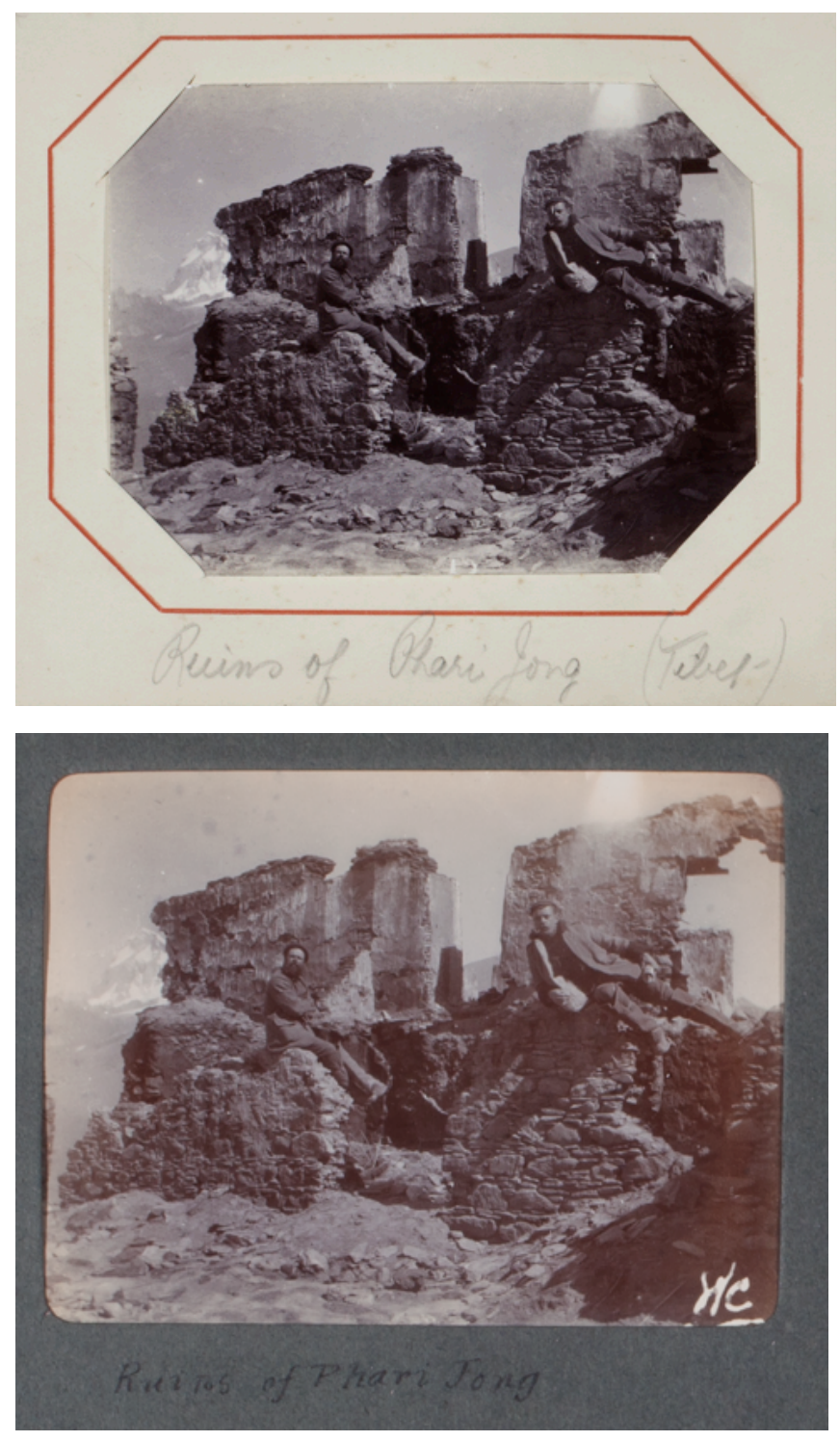

Fig. 32 Left: Ruins of Phari Jong (Tibet), Album From Tibet Expedition, 1904. 22680_1-18. Right: Ruins of Phari Jong, Hayman Album. 24796_1-12-2. 


\section{Technology}

The superiority of British modernization is also demonstrated through references to the colonizers' technology found in many of the photographs. The most obvious of these references is captioned "Field Telephone/Telegraph at Work." [fig. 33] In the photograph, a British man and two Tibetan men operate a British field telegraph. When the variants of the image from each album are compared, there is evidence of the scene being posed rather than candid. While constructing the supposedly candid scene of the men "at work," the British officer is posed as the dominant in charge of the situation, and the Tibetan men remain posed as assistants to the British operator. While the Tibetan men have been photographed in the same positions, the British commander is seen variably wearing a hat in one image and is without it in the other. ${ }^{105}$ This reveals that the Tibetan men were told to pose as assistants to the British operator while a number of different images were taken, constructing the supposedly candid scene of the men "at work." Such scenes demonstrating superiority are included in a number of images found in the British Telegraph members' photographic souvenir albums.

Less obvious depictions of technology and civil engineering are also included in the visual documentation of the occupation. Photographs of the landscape that include British-made roads, passageways, and telephone transmission poles are found throughout the albums. [fig. 34, for example] These are usually labeled as general views, or are captioned in similar ways to the other landscapes. John Falconer suggests that a calculated purpose drives the creation of these types of images, and that they are meant to implicitly represent the benefits of British modernization over rugged, disorderly terrain:

105 Recall the variants of the photograph "Tibetan Women" discussed in Analysis I. 
Whether taken for commercial sale, personal amusement, or documentary record, [British colonial photography], as in other colonial situations, implicitly reinforced a vision of western superiority and progress. ${ }^{106}$
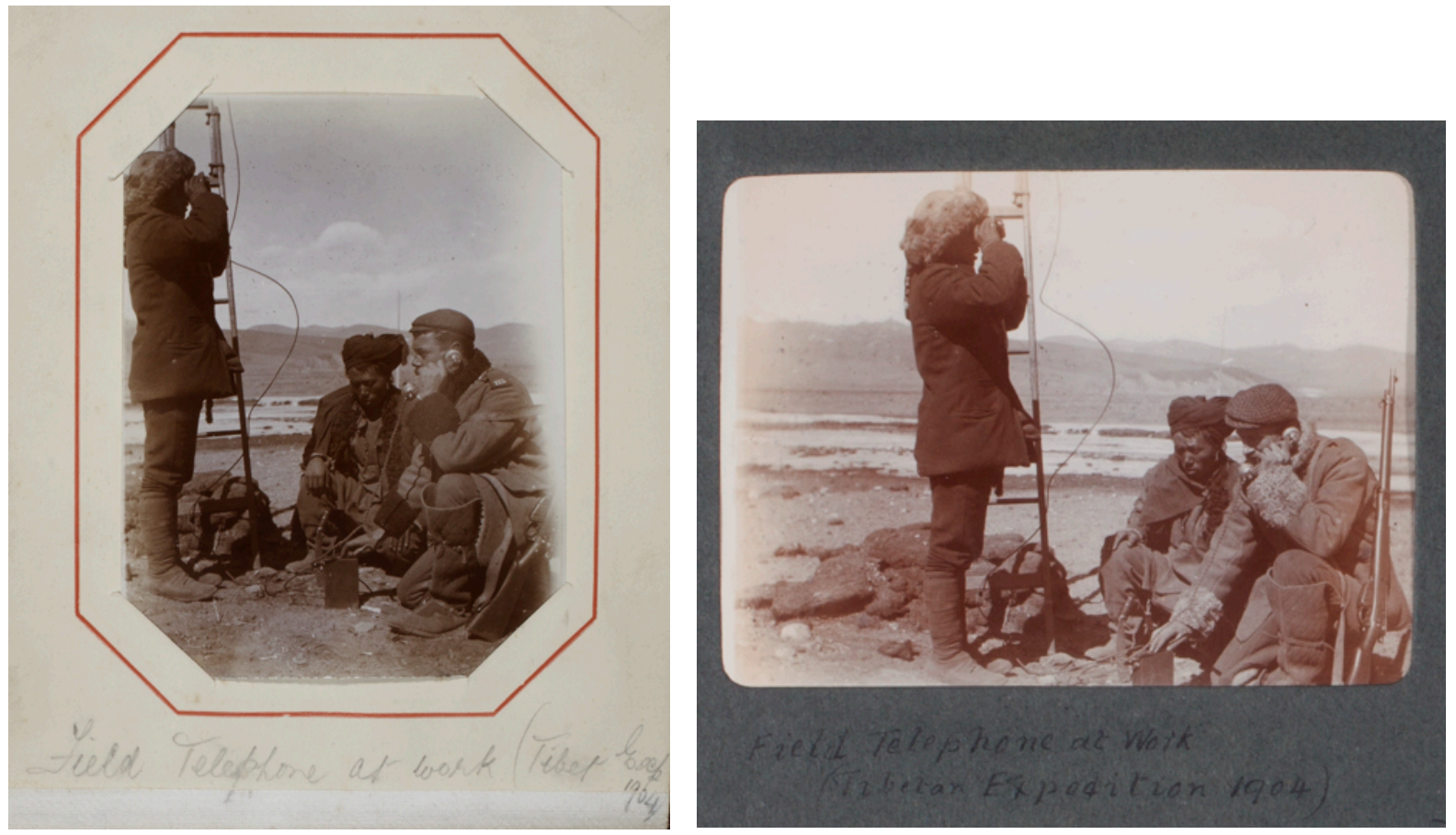

Fig. 33| Left:

Field Telephone at work (Tibet Exp 1904), Album From Tibet

Expedition, 1904 $226801-34$.

Right: Field

Telephone at

work (Tibetan

Expedition

1904), Hayman

Album. 24796 16-2.
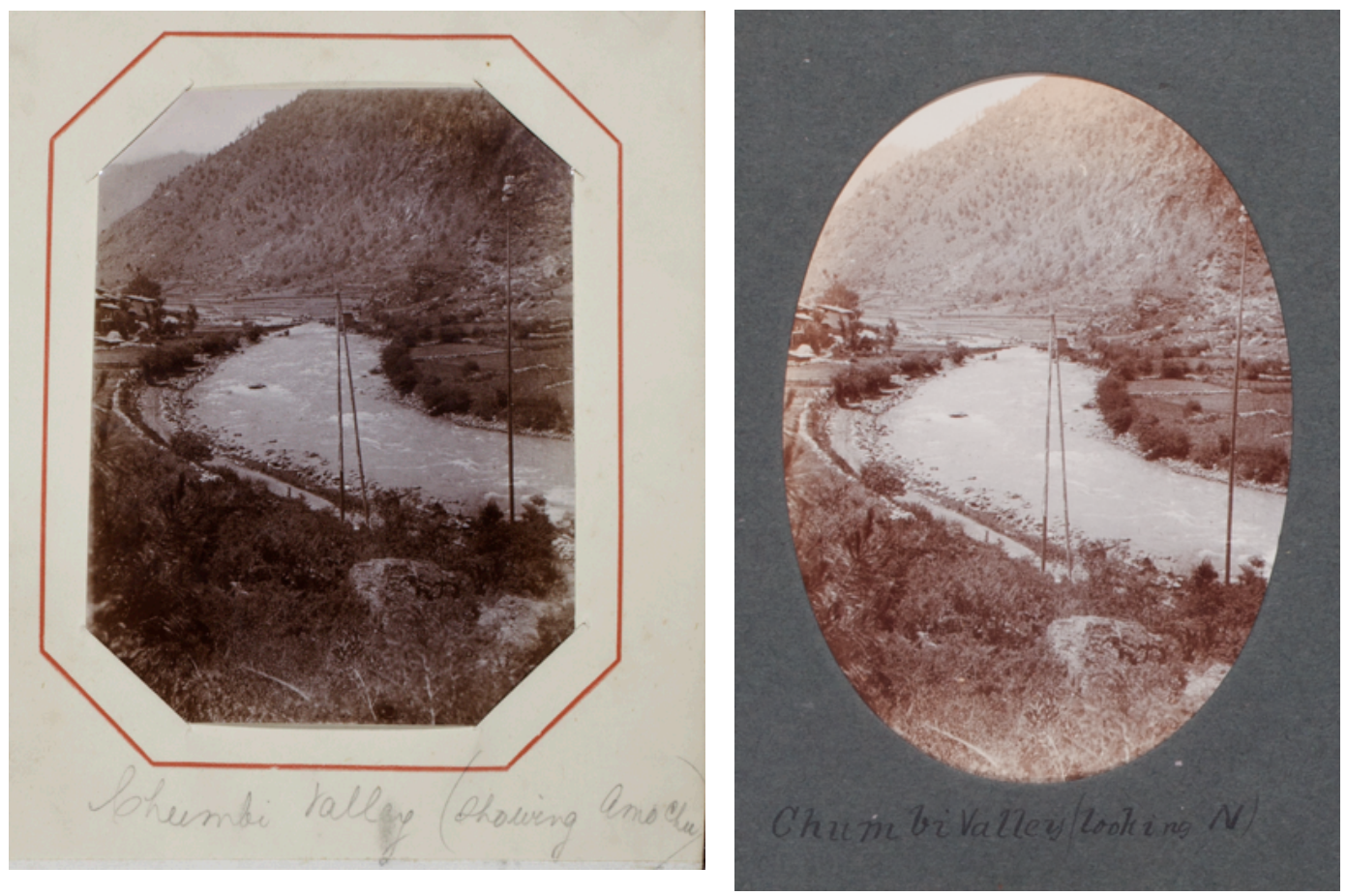

Fig. 34| Left: Chumbi Valley showing Amo Chu), Album From Tibet Expedition, 1904. 22680 126. Right: Chumbi Valley (looking N), Hayman Album. 24796_1-12-3.

${ }^{106}$ John Falconer and Louise Hide, Points of View, 71. 


\section{A Note on Landscapes}

Landscape photography has been discussed at great length in historical scholarship dedicated to photography, especially within research on specific landscape photographers. ${ }^{107}$ The landscape imagery included in the Field Telegraph albums is particularly interesting because it is some of the first photography taken of Tibet by the British. Particular attention was paid to more general views of Lhasa and the Chumbi Valley, as these were the primary regions where the Field Telegraph was stationed.

Because the landscape photographs in these albums were expediently made as documents on printing-out-papers, they are less striking than the large-format platinum prints taken by White during the same mission. It is worth noting, however, the influence that White's subject matter might have had on the photographer of the candid images, who often photographed landscapes and individuals from similar points of view.

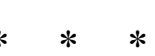

In Analysis I, a lack of descriptive information in the photographs' captions revealed the calculated process of anonymizing Tibetans. However, this chapter has demonstrated that the anonymization of Tibetans is not exclusively evidenced in the photographs of Tibetan individuals. In fact, an absence of description was also applied to Tibetan architecture and village views. By contrasting this minimal textual information with images that have been afforded more specific details, a trend favouring the documentation of British progress exposes these intentions embedded in the album.

107 See Falconer, India: Pioneering Photographers, 2001; Ryan and Schwartz, Picturing Place, 2003; Meyer and Deuel Meyer, In the Shadow of the Himalayas, 2006. 


\section{Analysis III: Constructed Narratives \& Relationships}

While it is important to analyze photographs to reveal the inherent bias of their photographer, it is equally as important to demonstrate how the albums work to characterize specific events for their intended audience. As was demonstrated in Chapter 1 of this thesis, textual information documenting certain events of the Younghusband Mission exist, but what could the Field Telegraph photographs contribute or alter in these histories? What constructed narratives have been assigned to the Younghusband Mission in these albums, and are any of these constructs still used today in discussions of Tibet? This information is important for understanding the appropriation of the images in publications and exhibitions that were outlined in both the introduction and literature survey. The following chapter outlines how photographs can be used to reveal these constructs in conjunct with existing textual information.

\section{The Gravesite}

One of the most peculiar photographs found in the albums is captioned "Graves of officers and men who fell during the Tibet Expedition 1904.” [fig. 35] A British soldier stares into the camera from the center of the image, standing in a confined cemetery constructed by the mission members to bury their own dead. Details are not given on how the men might have died, but the caption dictates that the men "fell," insinuating the occurrence of some sort of altercation. However, no other photograph in the albums alludes to a battle aside from this image of the gravesite.

John Claude White's photographs, which make up the majority of the official British documentation of the invasion, do not include a single image of war. However, thanks to personal papers and narrative accounts belonging to other mission members, we know that a number of battles took place when the British first entered the Chumbi Valley from Sikkim. Before invading the region, the British camped out in Sikkim for three months, attempting to 
verbally negotiate entry with the Tibetans. When these attempts at negotiation failed,

Younghusband ordered his men to move north and cross the border in December of 1903.108
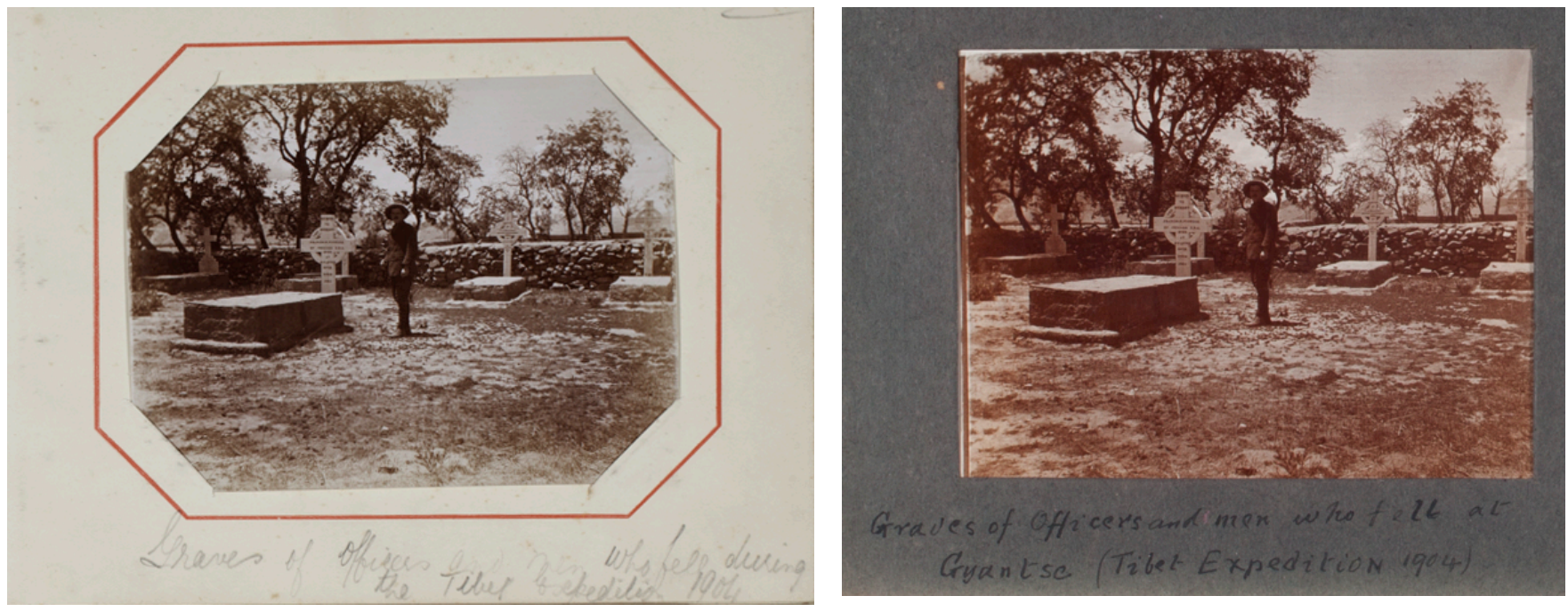

Fig. 35 | Left: Graves of officers and men who fell during the Tibet expedition, 1904, Album From Tibet Expedition, 1904. 22680 1-45. Right: Graves of Officers and men who fell at Gyantse (Tibet Expedition 1904). Hayman Album. 24796_1-26-3.

The British forces were confronted by armed Tibetans at Guru, but the swords, spears, and front-loading matchlock rifles of the Tibetans were no match for the British soldiers' Maxim machine guns, cannons, and intensive military training. ${ }^{109}$ General Macdonald-

Younghusband's co-captain — requested that the Tibetans extinguish the fuses of their matchlock guns in exchange for a peaceful discussion. The Tibetans extinguished their fuses, rendering their guns inoperable, and the British opened fire on them with their Maxims, unleashing 400-600 rounds of ammunition per weapon per minute. ${ }^{110}$ An estimated two to three thousand Tibetans

\footnotetext{
108 These events are also discussed in some contemporary histories of the Younghusband Mission, outlined on pages 7-9 of this thesis.

${ }^{109}$ Kurt Meyer and Pamela Deuel Meyer, In the Shadow of the Himalayas: A Photographic Record by Fohn Claude White (Ahmedabad: Mapin Publishing, 2006), 89.

110 Kurt Meyer and Pamela Deuel Meyer provide a transcription of a journal entry of one of the mission members who witnessed the battle: "When the Tibetans had extinguished their fuses, the British soldiers opened fire with machine guns from the surrounding areas. It was as if the heroic Tibetan soldiers had had their hands disabled, and they fell on the waste land. The British invaders, having disabled the Tibetan soldiers, then savagely massacred them." See Kurt Meyer and Pamela Deuel Meyer, In the Shadow of the Himalayas, 89.
} 
were slaughtered during these initial encounters, while the Younghusband Mission in general is estimated to have claimed the lives of around two hundred British men.

Therefore, the inclusion of this gravesite for British men, with no mention of battles or the Tibetan lives lost, is an interesting photograph that retrospectively contributes to the constructed narrative of the Younghusband Mission. The photograph insinuates a heroism of the British troops, while displacing the unjust massacre of Tibetans from the visual memories of the mission. These two albums, having belonged to two different mission members, possess the same constructed narrative that was meant to serve as a memory of the expedition for members of the Field Telegraph. The deaths of the British men have been deemed worthy of this memory, while the inflicted war and massacre of the Tibetans is intentionally absent. ${ }^{111}$

After the battle, Younghusband led his barely-scathed troops straight into Lhasa, where on September 7, 1904 he forced Tibetan officials to sign the Convention Between Great Britain and Tibet (or the Treaty of Lhasa). Unsurprisingly, the treaty codified the submission of Tibet to the British, specifically identifying the Chumbi Valley as a region of long-term British occupation. ${ }^{112}$ 113

\section{The Chumbi Valley}

The forced occupation of the Chumbi Valley sheds light on some additional discrepancies in the albums. The valley is consistently mentioned in the captions as a landmark and point of geographical reference. Table 2 lists the amount of times the valley is mentioned in the captions, and where.

\section{Table 2. All Captions Referencing the Chumbi Valley}

\footnotetext{
111 This is not to say that no photographic evidence of the battles exists. In fact, a few photographers whose images are housed at the British Library almost exclusively dedicated their practice to war photography. The point here is that in the construction of these domestic memorial albums, the war images were intentionally excluded from the curation.

${ }^{112}$ Kurt Meyer and Pamela Deuel Meyer, In the Shadow of the Himalayas, 90.

113 A transcription of the treaty is found in Appendix C of this thesis.
} 


\begin{tabular}{|c|c|c|c|}
\hline $\begin{array}{c}\text { Album from Tibet } \\
\text { Expedition, } 1904 \\
\text { Identifier }\end{array}$ & Gaption & $\begin{array}{l}\text { Hayman Album } \\
\text { Identifier }\end{array}$ & Caption \\
\hline 22680_1-25 & $\begin{array}{l}\text { Political officer's house } \\
\text { (Chumbi) }\end{array}$ & 24796_1-3-3 & $\begin{array}{l}\text { The Residency, } \\
\text { Chumbi, Tibet }\end{array}$ \\
\hline 22680_1-23 & $\begin{array}{l}\text { Cantiliver Bridge } \\
\text { (Chumbi Valley) }\end{array}$ & 24796_1-4-3 & $\begin{array}{l}\text { Cantilever Bridge, } \\
\text { Chumbi }\end{array}$ \\
\hline 22680_1-6 & Chumbi Post (Tibet) & 24796_1-5-2 & Chumbi, Tibet \\
\hline 22680_1-16 & $\begin{array}{l}\text { Commissariat Godown } \\
\text { Chumbi (Tibet) }\end{array}$ & 24796_1-6-3 & $\begin{array}{l}\text { Comst. Godowns, } \\
\text { Chumbi }\end{array}$ \\
\hline 22680_1-26 & $\begin{array}{l}\text { Chumbi Valley } \\
\text { (showing Amo Cha) }\end{array}$ & 24796_1-12-3 & $\begin{array}{l}\text { Chumbi Valley } \\
\text { (Looking N) }\end{array}$ \\
\hline 22680_1-28 & $\begin{array}{l}\text { British NCO's Quarters } \\
\text { (Chumbi) }\end{array}$ & 24796_1-14-3 & $\begin{array}{l}\text { British NCO's Qts, } \\
\text { Chumbi }\end{array}$ \\
\hline 22680_1-40 & $\begin{array}{l}\text { General View (Chumbi } \\
\text { Valley) }\end{array}$ & 24796_1-16-3 & $\begin{array}{l}\text { Chumbi Valley (front } \\
\text { heights) }\end{array}$ \\
\hline 22680_1-48 & $\begin{array}{l}\text { General View, Chumbi } \\
\text { Valley }\end{array}$ & 24796_1-17-3 & $\begin{array}{l}\text { Chumbi Valley (from } \\
\text { heights) }\end{array}$ \\
\hline 22680_1-37 & $\begin{array}{l}\text { Field Telegraph of } \\
\text { Chumbi }\end{array}$ & 24796_1-22-3 & $\begin{array}{l}\text { Field Telegraph Office } \\
\text { (Chumbi) }\end{array}$ \\
\hline 22680_1-43 & $\begin{array}{l}\text { General View of } \\
\text { Chumbi (Tibet) }\end{array}$ & 24796_1-26-2 & $\begin{array}{l}\text { Chumbi Post (from } \\
\text { West) }\end{array}$ \\
\hline
\end{tabular}

Knowing that the British forcibly dominated and occupied the Chumbi Valley during the

mission explains why many of the photographs were taken in the area. In spite of this, the albums include no reference to this forceful occupation. The reasoning for this is perhaps obvious: why draw attention to the autocratic actions of an invasion in which one was a participant? As these objects are evidence of the dissemination of colonial mission souvenirs, it is interesting to see what types of memories have been developed for the members of the Field Telegraph. These albums were meant to be objects of fond memories (even if constructed), rather than of objective historical documentation.

\section{Tibetan Staff \& British Officials}

In addition to Tibetans being coerced into signing the treaty with Younghusband, they were also designated as staff for many of the British officials who ran occupational posts. A photograph of the "Transport Section" shows a number of Tibetan attendants posing with their 
commanding British officers. [fig. 36] The image of imperially decorated British officers working with designated Tibetan staff reifies two colonial messages. The first is that the submissive Tibetans are both inferior and benefitting from their employment and interactions with the British officers. The second is that some sort of respectable amicability existed between the colonizers and the colonized. However, the subjects' arrangement and poses actually make them seem unnatural, and the scene looks rather rigid and forced.
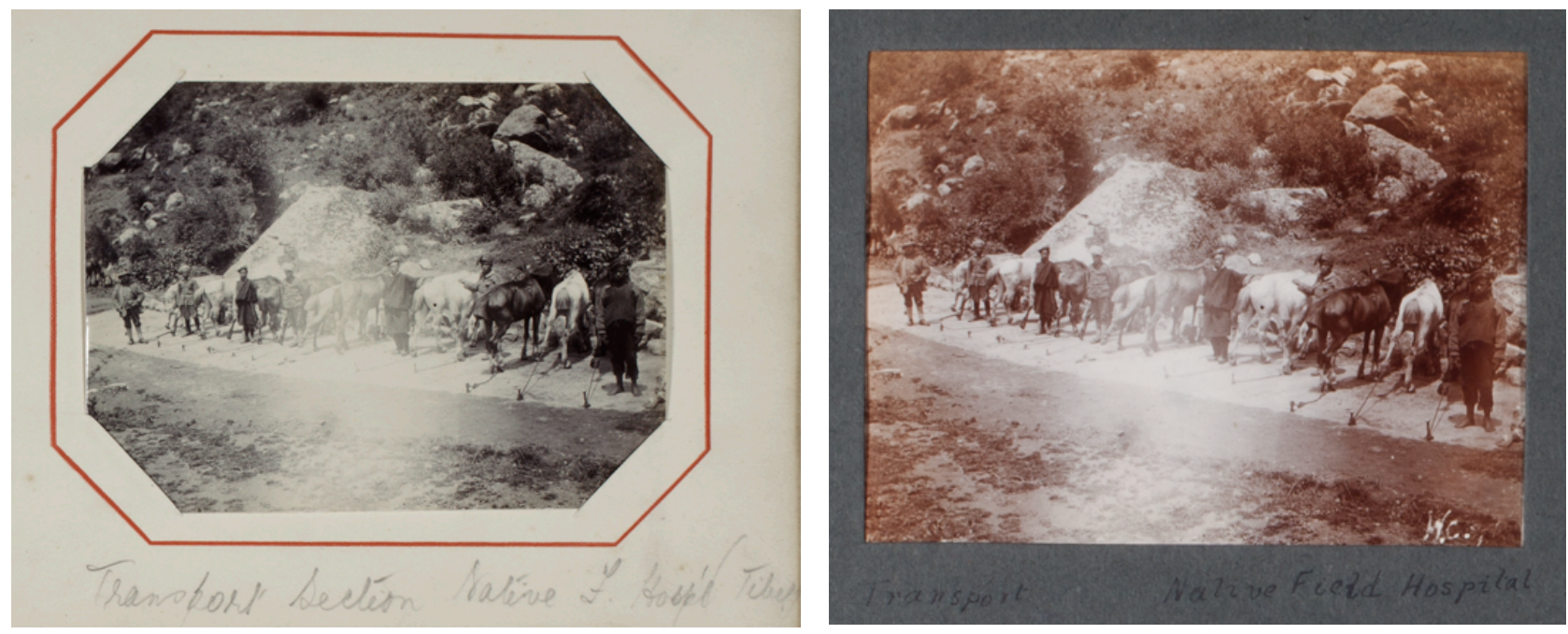

Fig. 36 Left: Transport Section, Native Field Hospital, Album From Tibet Expedition, 1904. 22680_1-47. Right: Transport, Native Field Hospital. Hayman Album. 24796_1-14-2.

The image captioned "Telegraph Staff” [fig. 38] also depicts standard colonial tropes that we can now identify as evidence of an oppressive relationship between the colonizer and colonized. The British officer of the Telegraph Post is seated in the centre of his surrounding subjects, posed regally as his Tibetan staff stand above or sit below his seat. This is likely the same officer observed in the image "Field Telephone/Telephone at work," [fig. 34] which was previously discussed. Once again, this arrangement of subjects is meant to act as a demonstration 
of the benefits of British modernization of Tibet, while also maintaining a narrative of submission and gratefulness for the British by Tibetans.

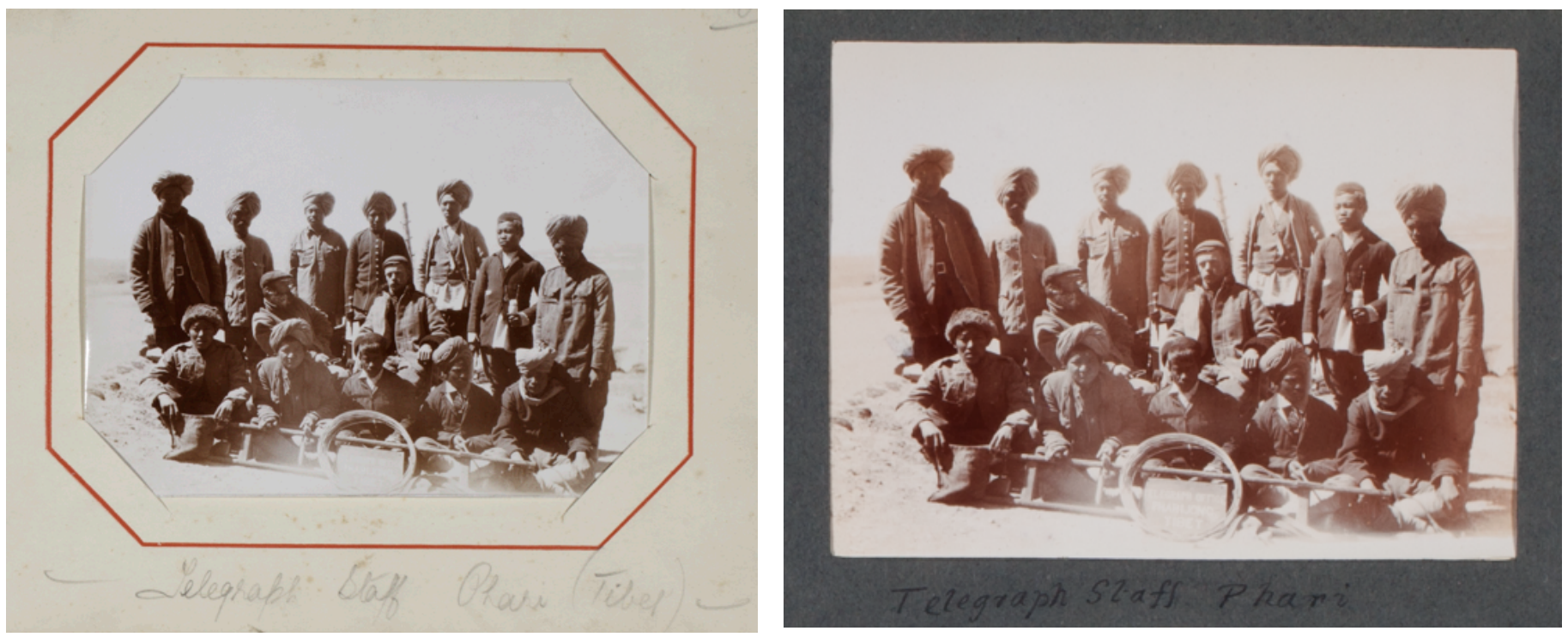

Fig. 38 Left: Telegraph Staff Phari (Tibet), Album From Tibet Expedition, 1904. 22680_1-49.

Right: Telegraph Staff Phri. Hayman Album. 24796_1-19-2.

$$
* \quad * \quad *
$$

It is important to incorporate analyses of photographs taken during the Younghusband

Mission with other primary textual documentation to reveal the nuances in narratives of the invasion that have been constructed by the British colonizers. Using photographs in research can assist with better articulating these constructs, and can strengthen analyses of these selective histories. As evidenced by a number of the photographs included in the Field Telegraph albums, including an image of a British gravesite, images of the Chumbi Valley, and photographs of Tibetan staff with British officials, justifications for the invasion not only manifested in textually recorded histories, but also in the visual histories of the mission. 


\section{Conclusion}

Having barely lasted two years, the Younghusband Mission (1903-1904) is often

overlooked in histories of the British empire. Despite being short-lived, the range of photographic works created during the mission are still used in many of the mission's textual histories.

However, in these contexts, the images are often relegated to serve as illustrations, and have not been considered in the greater body of critical scholarship on colonial photography.

The preceding analyses focus on two specific albums acquired by the Archive of Modern Conflict. Though purchased at separate times, provenance research revealed that the objects were souvenirs of British officers of the Field Telegraph, presented to the men upon their return to England and British India from the Younghusband Mission. The objects are unique because they are personal in nature, unlike the official photographs that are traditionally associated with the mission, which are currently housed at the British Library and Royal Geographical Society.

In this thesis, I have aimed to demonstrate how a material evaluation of the Younghusband Mission photographs contributes a wealth of information to our understanding of both the 1904 invasion and Tibet's greater history. By first outlining the photographic conventions ascribed to Tibet and Tibetans leading up to the mission, I have provided a context for identifying any tropes in the albums' subject matter. Additionally, I have included provenance research on the objects to contribute to the understanding of historical constructs that were perpetuated by the photographs. This demonstration, however, is not exhaustive, and therefore demands further study of photographs and albums of Tibet created during the British colonial era, which lasted well into the mid-twentieth century.

The three material analyses of the albums are demonstrations of how photographs of the Mission can be used to reveal the imperial intentions of both colonial photographers and the 
colonizers in general. Understanding the tradition of photographing Tibetan "types" informs the way the ethnographic imagery included in the albums should be interpreted, exposing their allegedly candid nature. Additionally, analyzing the frequent inclusion of photographs of British infrastructure in the albums implicitly contributes to the narrative of British superiority within the occupied land. Finally, incorporating a material analysis of the photographs' subject matter in relation to the textual histories of the mission reveals the methodical construction of a cheerful history meant specifically for members of the Field Telegraph. 
Appendix A Album from Tibet Expedition, 1904 Catalogue

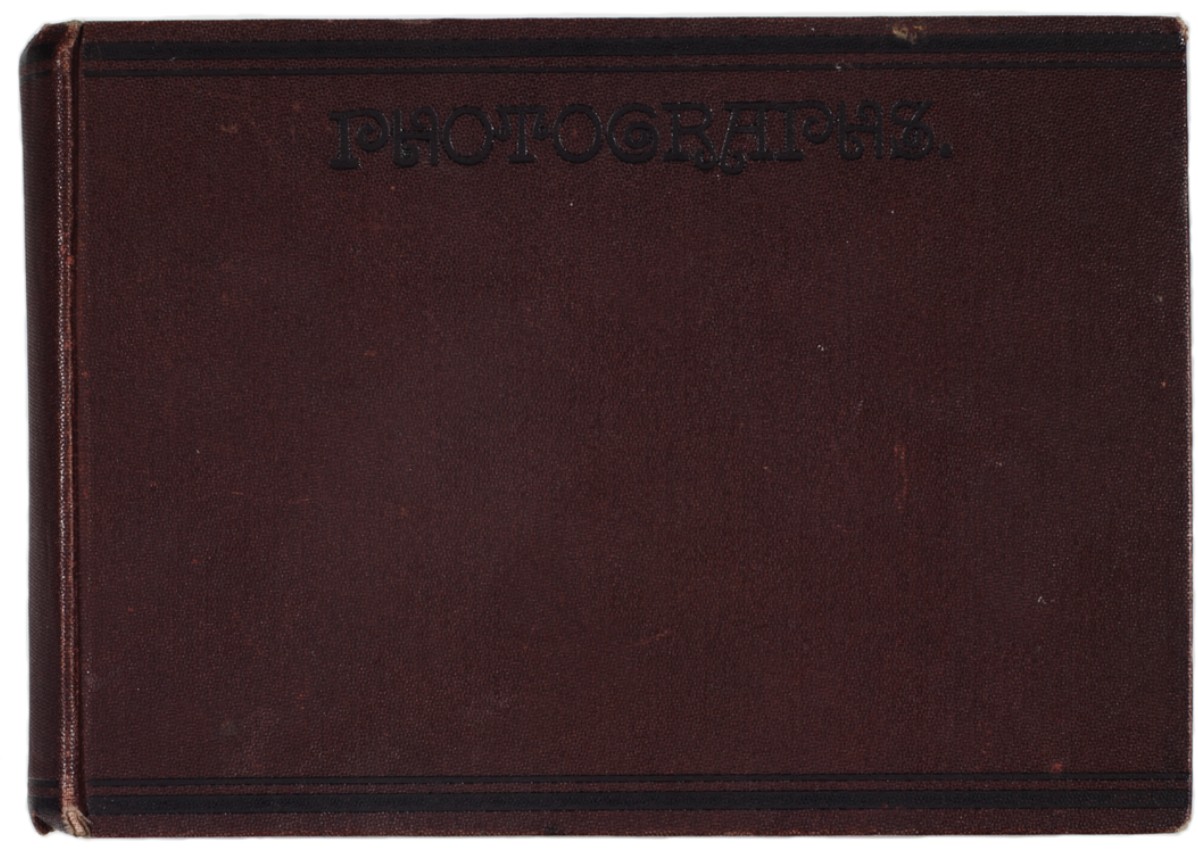

Description Front cover.

Dimensions 12.5 x $17 \mathrm{~cm}$ (2.5 cm deep) AMC 22680_1 


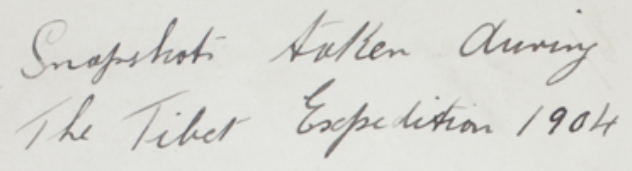

Description Inside front cover, captioned "Snapshots taken during The Tibet Expedition 1904" in black ink.

AMC 22680_1-2
Description Recto front leaf. AMC 22680_1-3

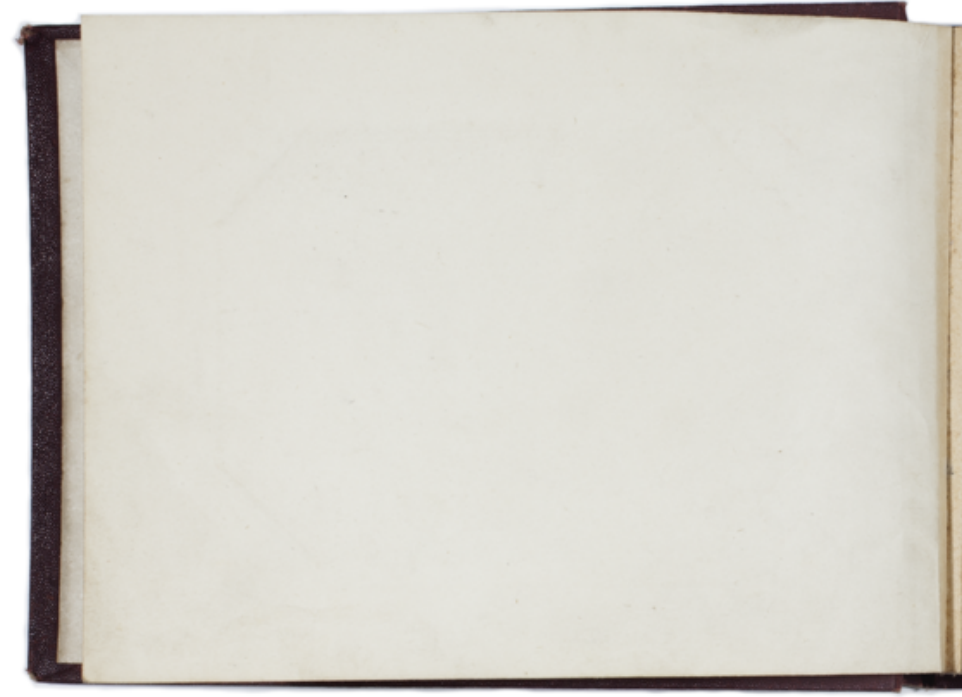

Description Verso front leaf. AMC 22680_1-4

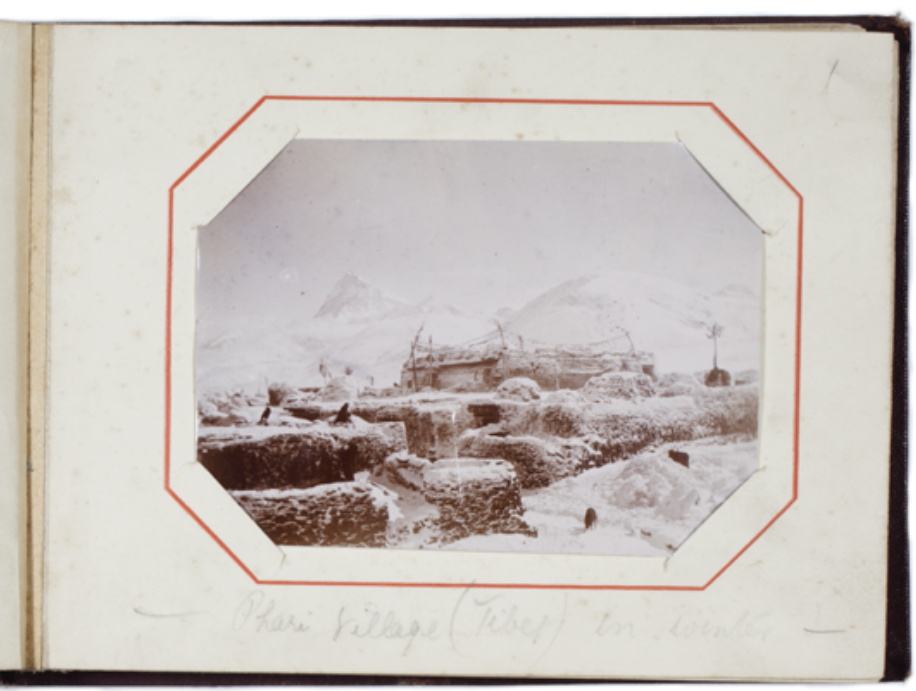

Caption Phari Village (Tibet) in winter Photographer initialed W.C.

Date ca. 1903-1904

Medium Collodion silver print on printing-out paper.

Dimensions 7 x $10 \mathrm{~cm}$

AMC 22680_1-5 


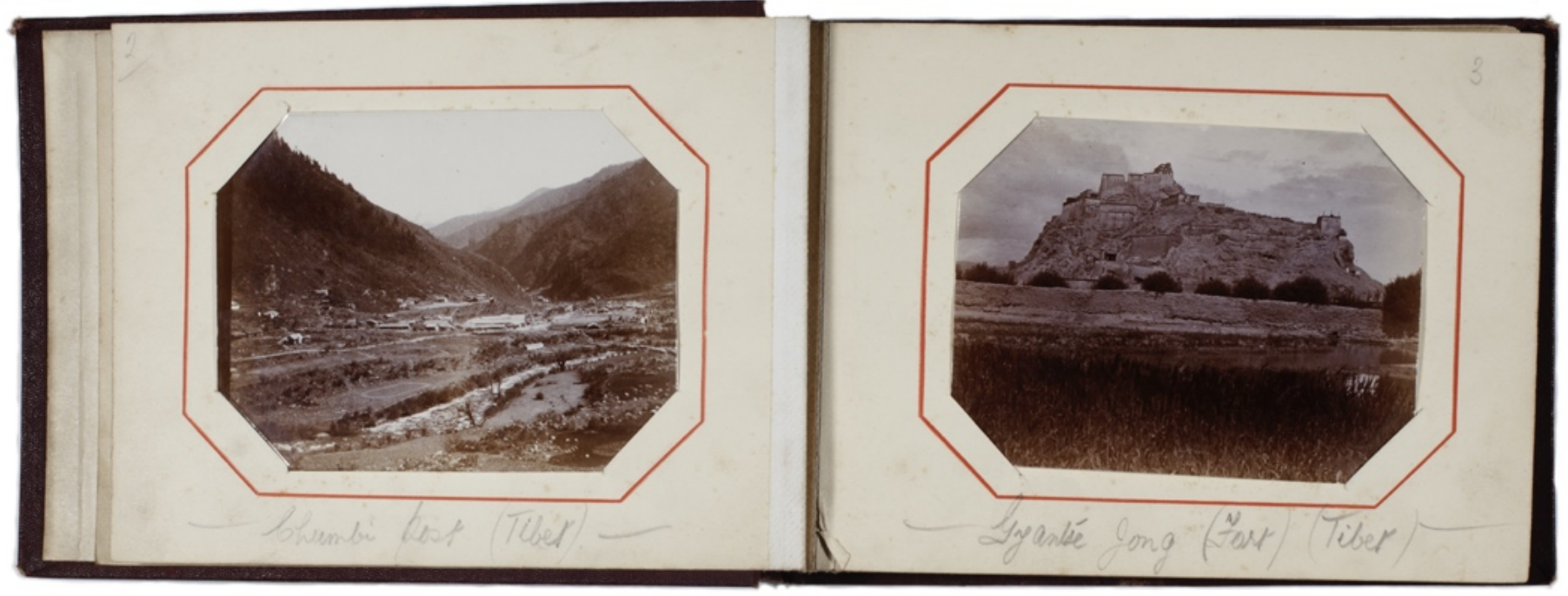

Caption Chumbi Post (Tibet)

Photographer initialed W.C.

Date ca. 1903-1904

Medium Collodion silver print on printing-out paper.

Dimensions 7 x $10 \mathrm{~cm}$

AMC 22680_1-6
Gaption Gyantse fong (Fort) (Tibet)

Photographer initialed W.C.

Date ca. 1903-1904

Medium Collodion silver print on printing-out paper.

Dimensions 7 × $10 \mathrm{~cm}$

AMC 22680_1-7
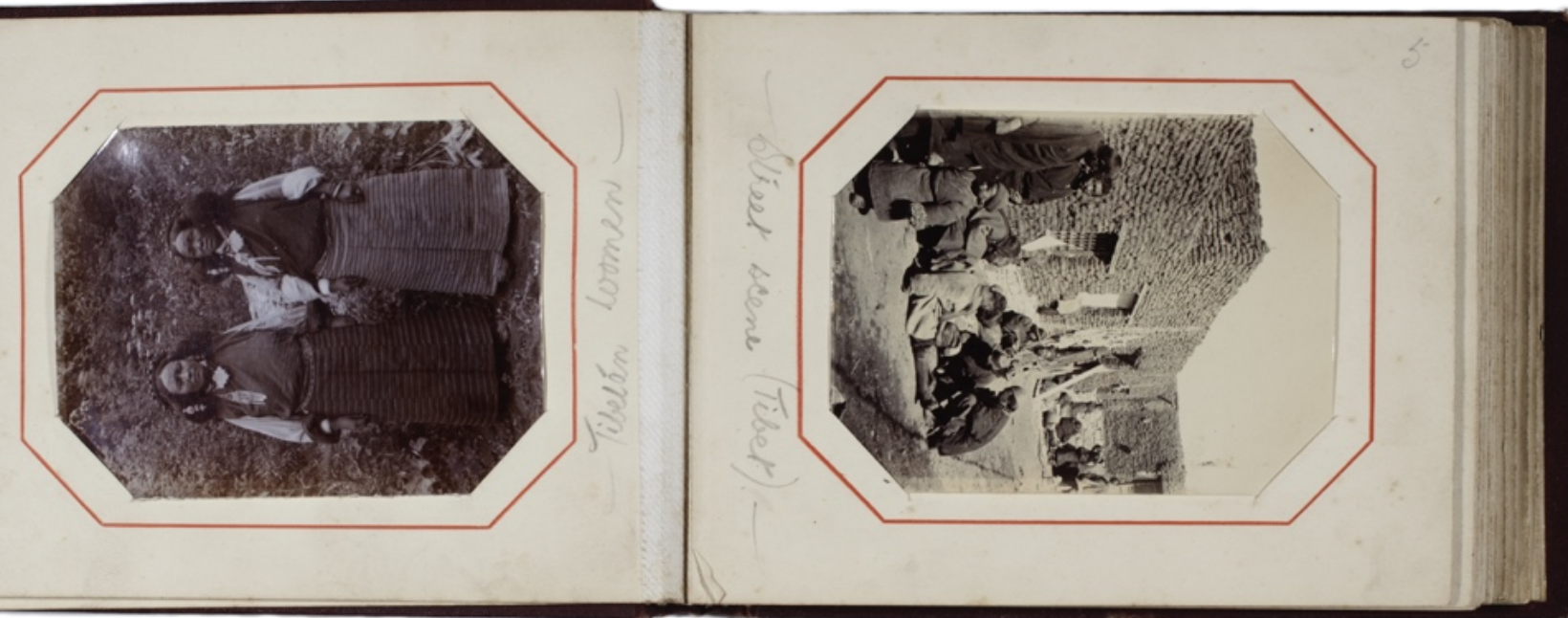

Caption Tibetan Women

Photographer initialed W.C.

Date ca. 1903-1904

Medium Collodion silver print on printing-out paper.

Dimensions $10 \times 7 \mathrm{~cm}$

AMC 22680_1-8
Gaption Street Scene (Tibet)

Photographer initialed W.C.

Date ca. 1903-1904

Medium Collodion silver print on printing-out paper.

Dimensions $10 \times 7 \mathrm{~cm}$

AMC 22680_1-9 


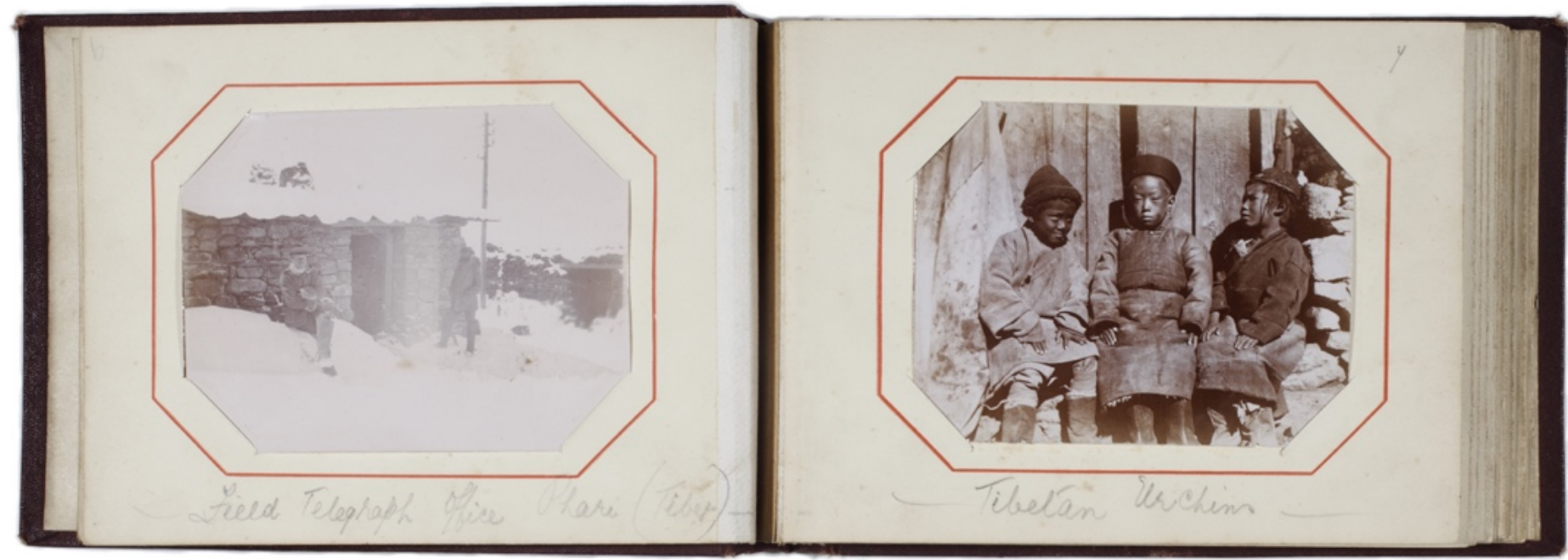

Caption Field Telegraph Office Phari (Tibet)

Photographer initialed W.C.

Date ca. 1903-1904

Medium Collodion silver print on printing-out paper.

Dimensions 7 x $10 \mathrm{~cm}$

AMC 22680_1-10
Caption Tibetan Urchins

Photographer initialed W.C.

Date ca. 1903-1904

Medium Collodion silver print on printing-out paper.

Dimensions 7 × $10 \mathrm{~cm}$

AMC 22680_1-11

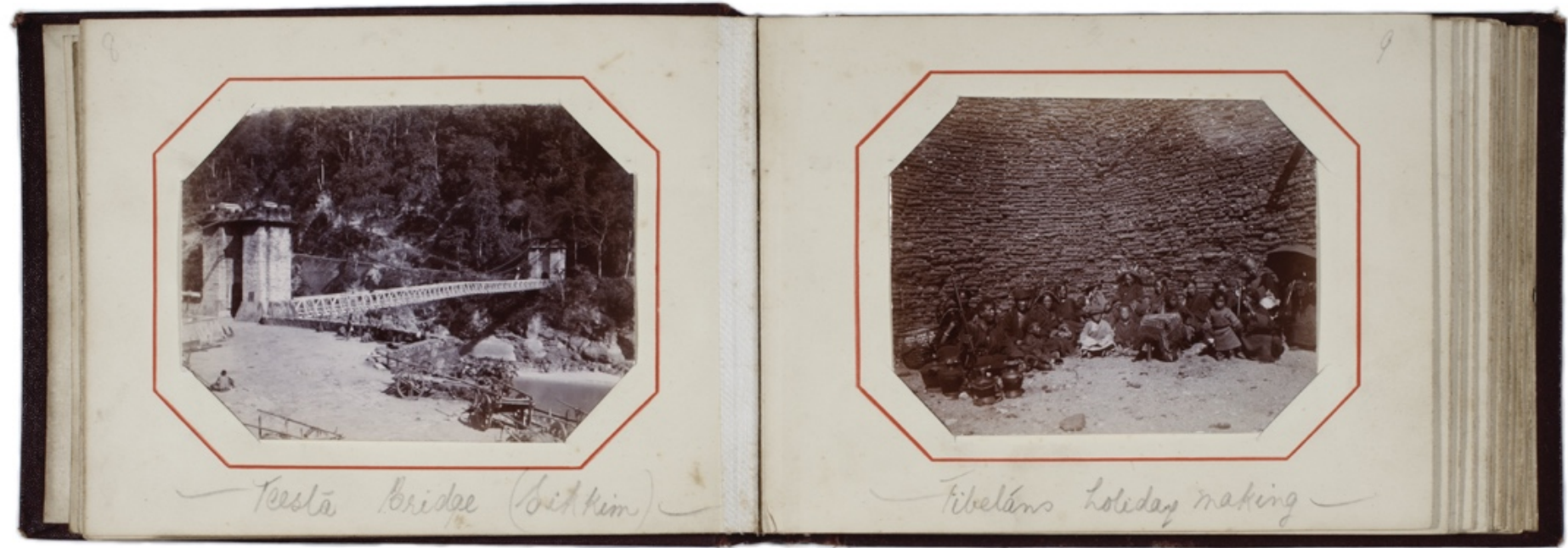

Caption Teesta Bridge (Sikkim)

Photographer initialed W.C.

Date ca. 1903-1904

Medium Collodion silver print on printing-out paper.

Dimensions $7 \times 10 \mathrm{~cm}$

AMC 22680_1-12
Caption Tibetans holiday making

Photographer initialed W.C.

Date ca. 1903-1904

Medium Collodion silver print on printing-out paper.

Dimensions 7 × $10 \mathrm{~cm}$

AMC 22680_1-13 


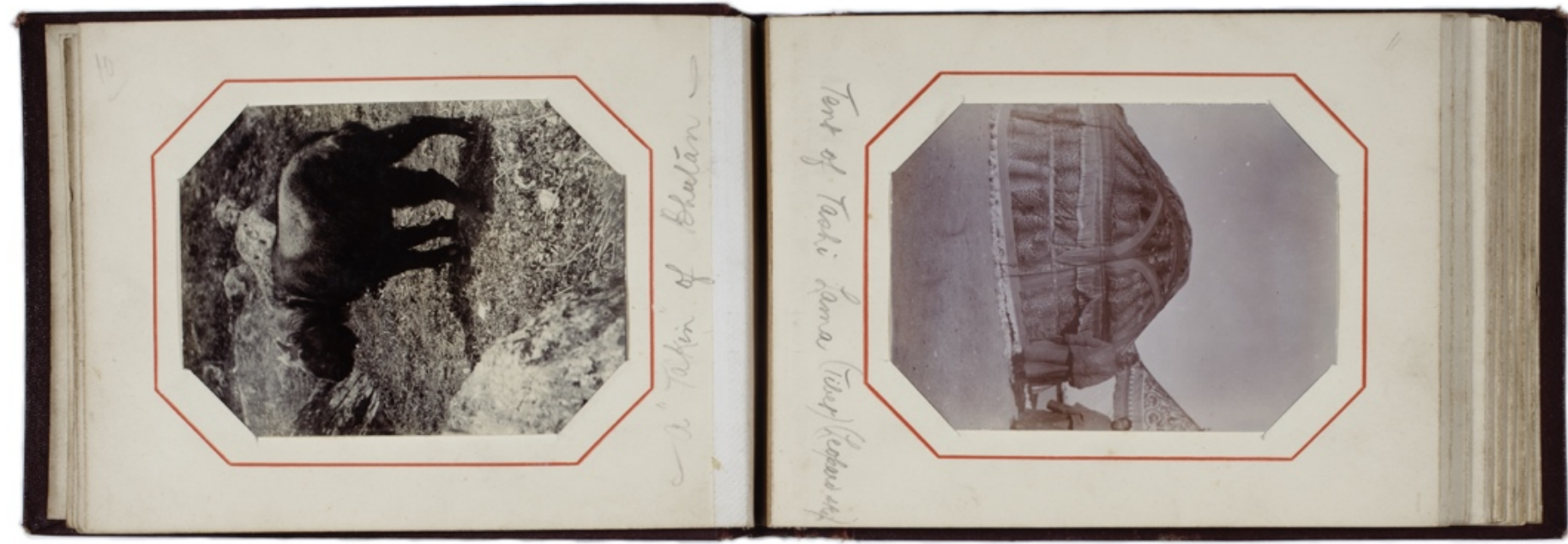

Caption $A$ Takin of Bhutan

Photographer initialed W.C.

Date ca. 1903-1904

Medium Collodion silver print on printing-out paper.

Dimensions $10 \times 7 \mathrm{~cm}$

AMC 22680_1-14
Gaption Tent of Tashi Lama (Tibet) (Leopard skins)

Photographer initialed W.C.

Date ca. 1903-1904

Medium Collodion silver print on printing-out paper.

Dimensions 7 × $10 \mathrm{~cm}$

AMC 22680_1-15

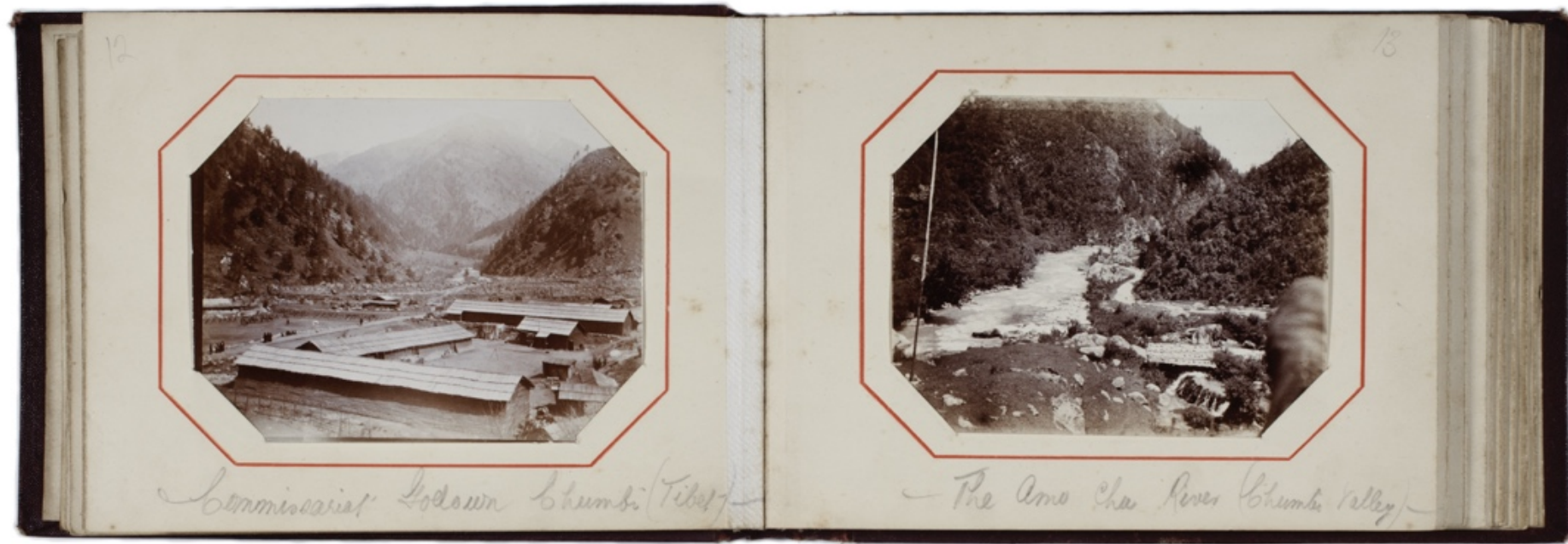

Gaption Commissariat Godown Chumbi (Tibet)

Photographer initialed W.C.

Date ca. 1903-1904

Medium Collodion silver print on printing-out paper.

Dimensions 7 × $10 \mathrm{~cm}$

AMC 22680_1-16
Caption The Amo Cha River (Chumbi Valley)

Photographer initialed W.C.

Date ca. 1903-1904

Medium Collodion silver print on printing-out paper.

Dimensions 7 x $10 \mathrm{~cm}$

AMC 22680_1-17 


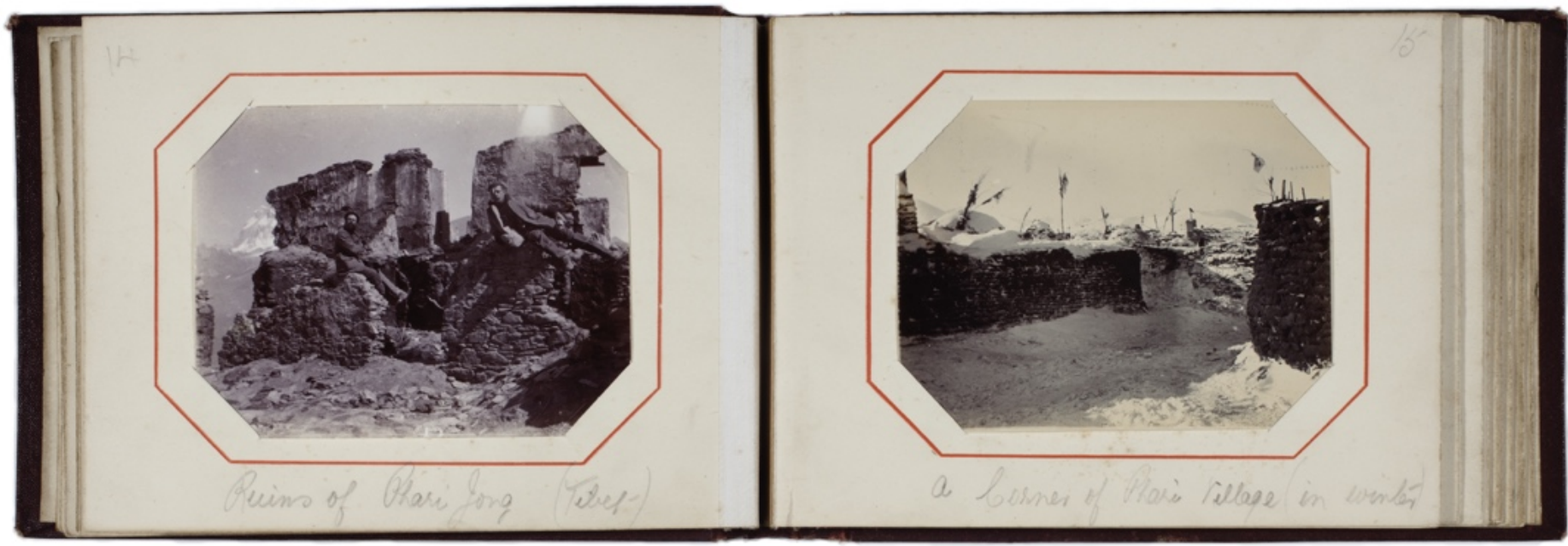

Caption Ruins of Phari fong (Tibet)

Photographer initialed W.C.

Date ca. 1903-1904

Medium Collodion silver print on printing-out paper.

Dimensions $7 \times 10 \mathrm{~cm}$

AMC 22680_1-18
Gaption $A$ Corner of Phari Village (in winter)

Photographer initialed W.C.

Date ca. 1903-1904

Medium Collodion silver print on printing-out paper.

Dimensions $7 \times 10 \mathrm{~cm}$

AMC 22680_1-19

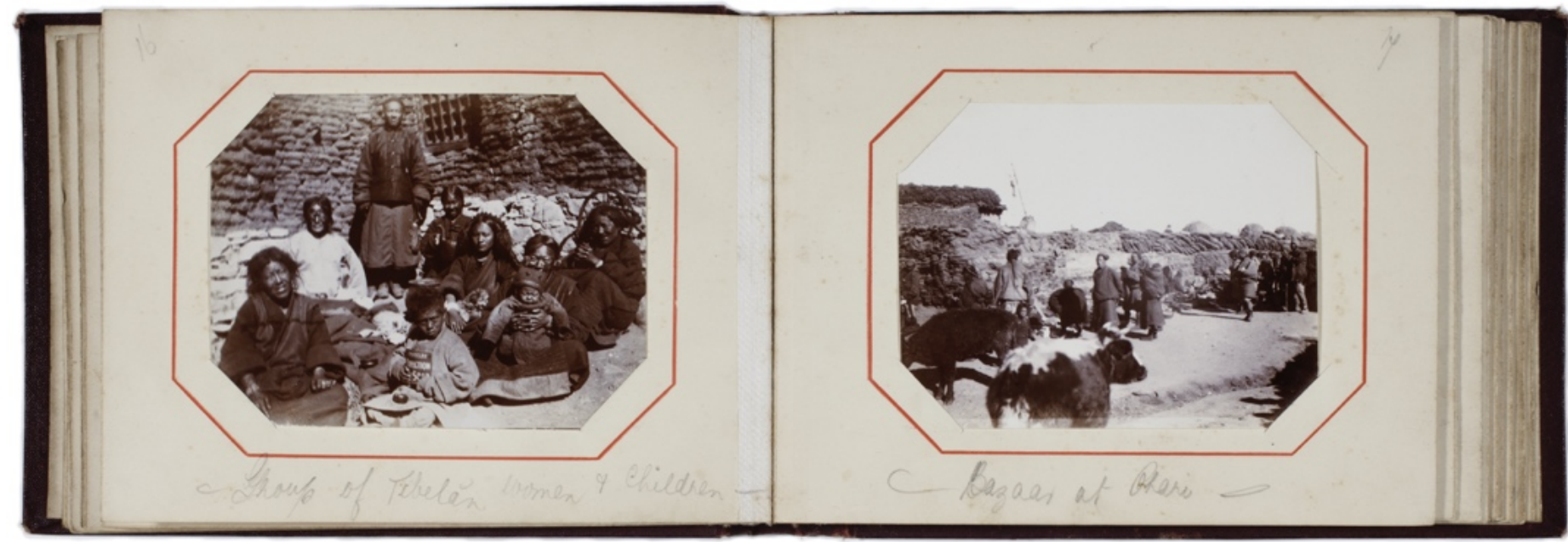

Gaption Group of Tibetan Women + Children Photographer initialed W.C.

Date ca. 1903-1904

Medium Collodion silver print on printing-out paper.

Dimensions 7 x $10 \mathrm{~cm}$

AMC 22680_1-20
Caption Bazaar at Phari

Photographer initialed W.C.

Date ca. 1903-1904

Medium Collodion silver print on printing-out paper.

Dimensions 7 x $10 \mathrm{~cm}$

AMC 22680_1-21 


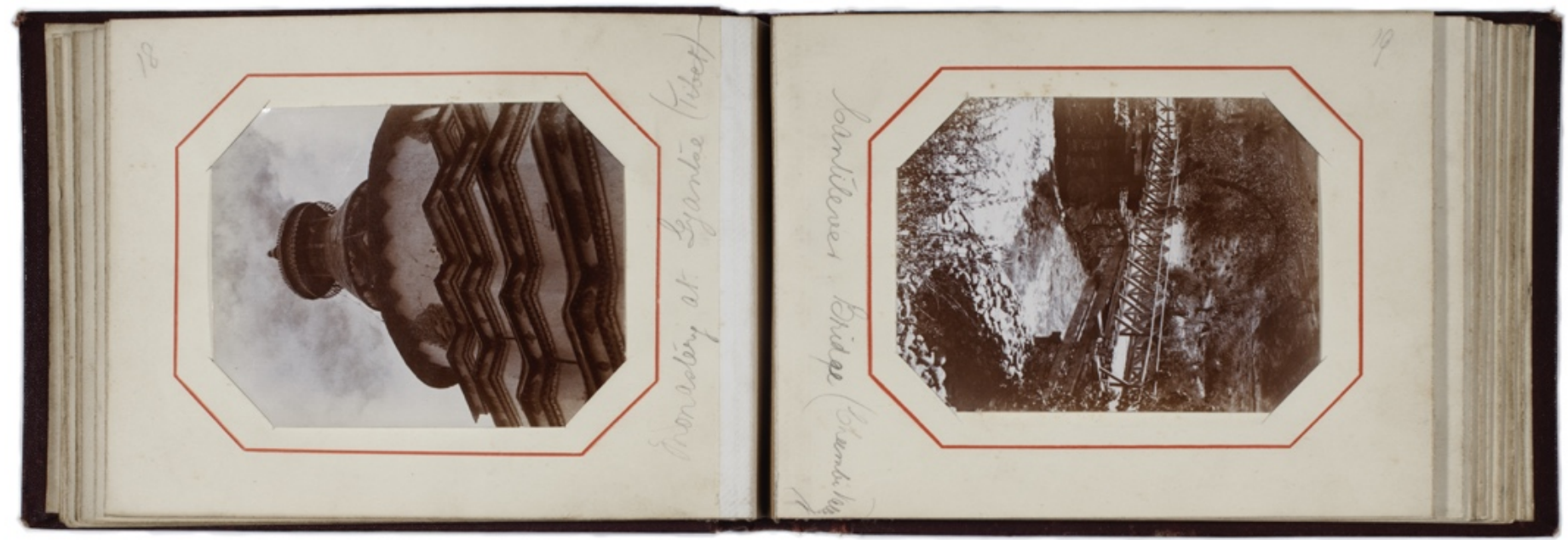

Gaption Monastery at Gyantse (Tibet)

Photographer initialed W.C.

Date ca. 1903-1904

Medium Collodion silver print on printing-out paper.

Dimensions $10 \times 7 \mathrm{~cm}$

AMC 22680_1-22
Caption Cantilever Bridge (Chumbi Valley)

Photographer initialed W.C.

Date ca. 1903-1904

Medium Collodion silver print on printing-out paper.

Dimensions $10 \times 7 \mathrm{~cm}$

AMC 22680_1-23

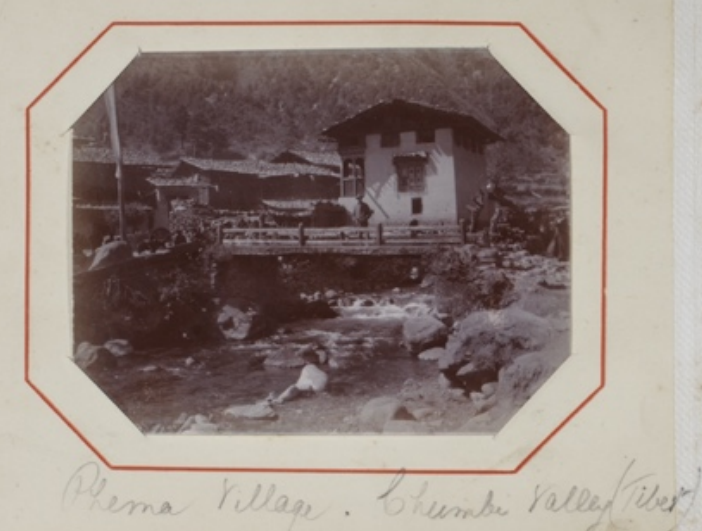

Caption Phema Village, Chumbi Valley (Tibet)

Photographer initialed W.C.

Date ca. 1903-1904

Medium Collodion silver print on printing-out paper.

Dimensions 7 x $10 \mathrm{~cm}$

AMC 22680_1-24
Gaption Political officer's house (Chumbi)

Photographer initialed W.C.

Date ca. 1903-1904

Medium Collodion silver print on printing-out paper.

Dimensions 7 x $10 \mathrm{~cm}$

AMC 22680_1-25 


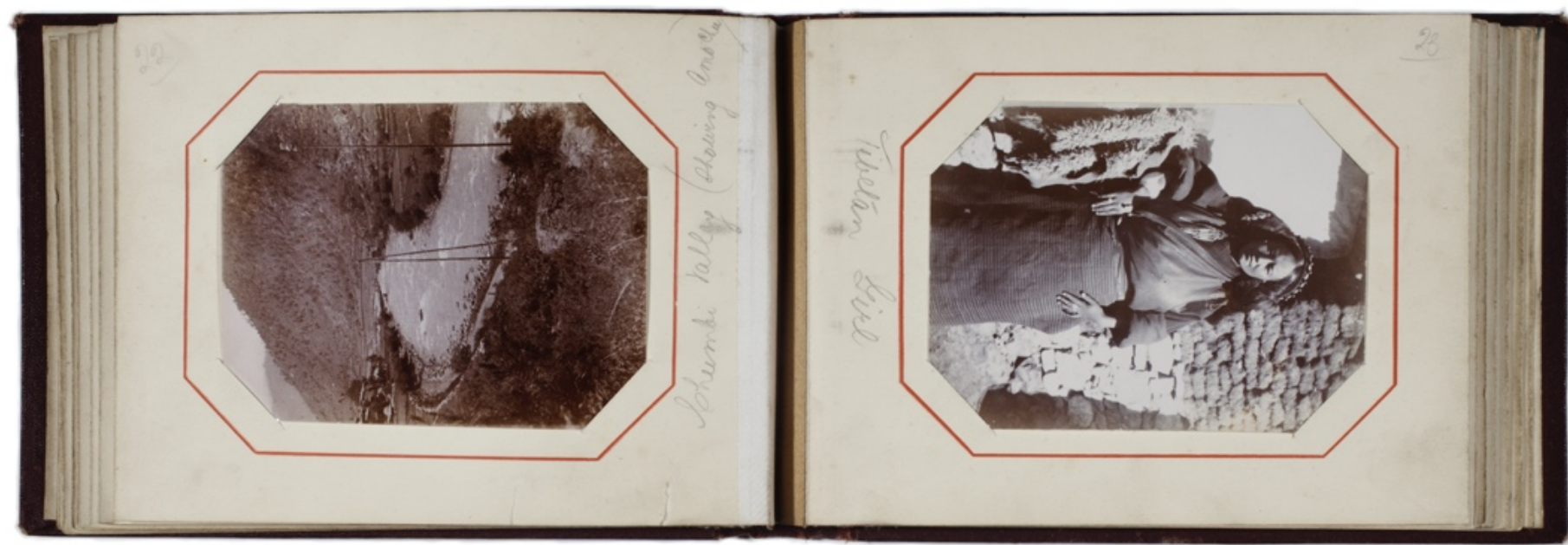

Caption Chumbi Valley (showing Amo Cha)

Photographer initialed W.C.

Date ca. 1903-1904

Medium Collodion silver print on printing-out paper.

Dimensions $10 \times 7 \mathrm{~cm}$

AMC 22680_1-26
Gaption Tibetan Girl

Photographer initialed W.C.

Date ca. 1903-1904

Medium Collodion silver print on printing-out paper. Dimensions $10 \times 7 \mathrm{~cm}$ AMC 22680_1-27

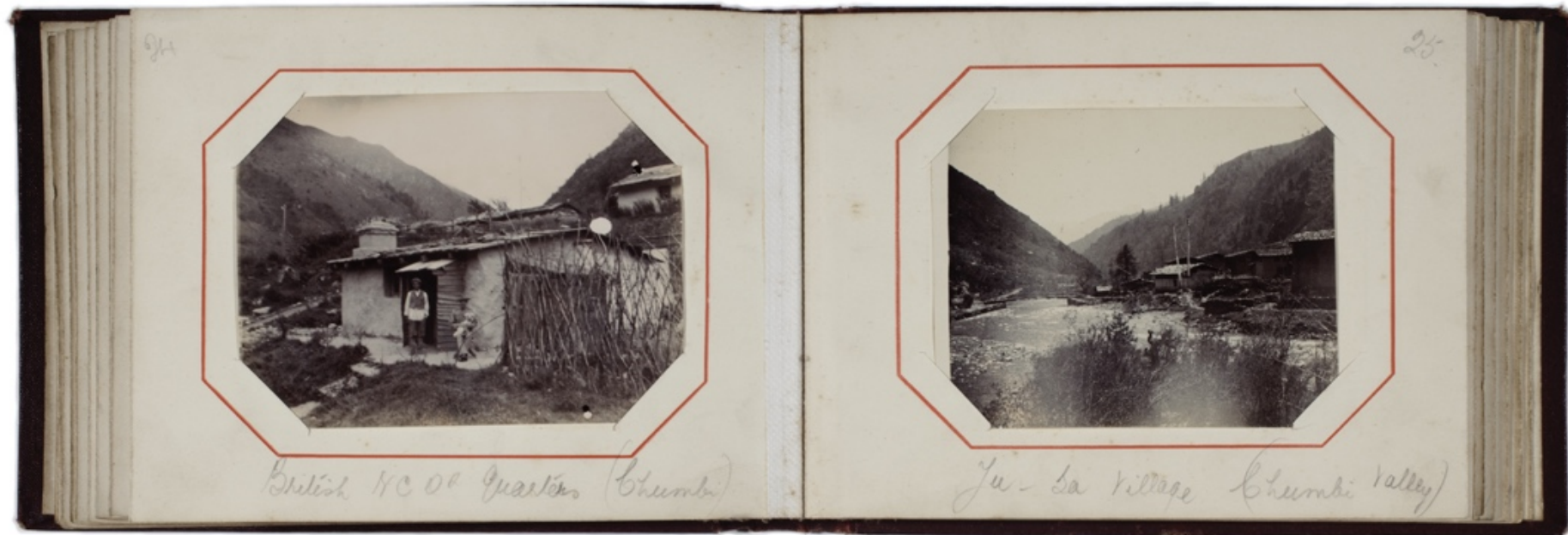

Gaption British NCO's Quarters (Chumbi)

Photographer initialed W.C.

Date ca. 1903-1904

Medium Collodion silver print on printing-out paper.

Dimensions 7 x $10 \mathrm{~cm}$

AMC 22680_1-28
Caption $\mathcal{f} u-S a$ Village (Chumbi)

Photographer initialed W.C.

Date ca. 1903-1904

Medium Collodion silver print on printing-out paper.

Dimensions 7 × $10 \mathrm{~cm}$

AMC 22680_1-29 


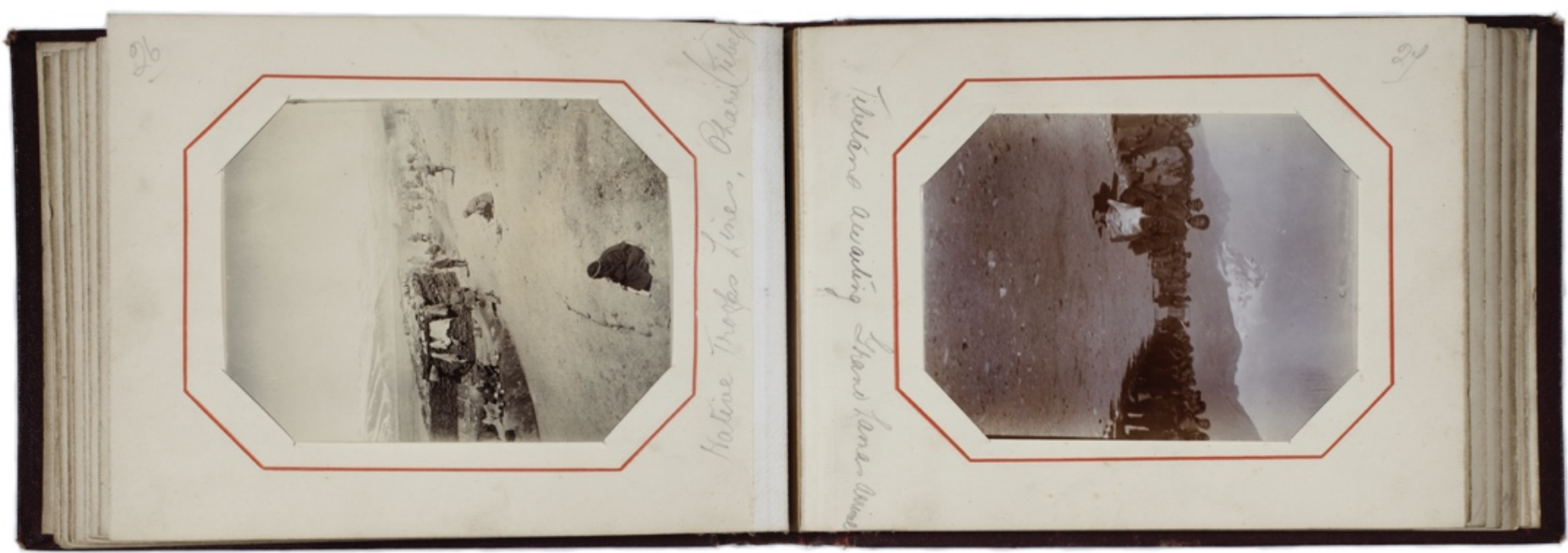

Caption Native Troops Lines, Phari (Tibet)

Photographer initialed W.C.

Date ca. 1903-1904

Medium Collodion silver print on printing-out paper.

Dimensions $10 \times 7 \mathrm{~cm}$

AMC 22680_1-30
Caption Tibetans Awaiting Grand Lama's Arrival Photographer initialed W.C.

Date ca. 1903-1904

Medium Collodion silver print on printing-out paper.

Dimensions $10 \times 7 \mathrm{~cm}$

AMC 22680_1-31

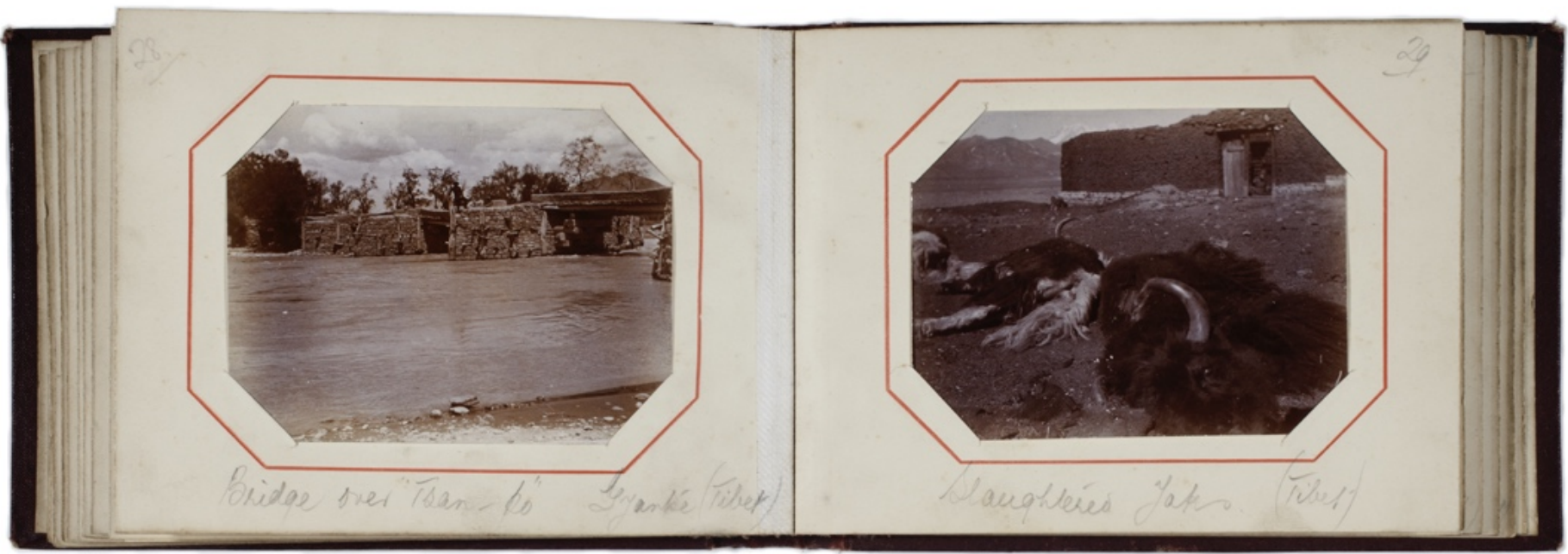

Gaption Bridge over "Tsan-po" Gyantse (Tibet)

Photographer initialed W.C.

Date ca. 1903-1904

Medium Collodion silver print on printing-out paper.

Dimensions $10 \times 7 \mathrm{~cm}$

AMC 22680_1-32
Gaption Slaughtered Taks (Tibet)

Photographer initialed W.C.

Date ca. 1903-1904

Medium Collodion silver print on printing-out paper.

Dimensions $10 \times 7 \mathrm{~cm}$

AMC 22680_1-33 


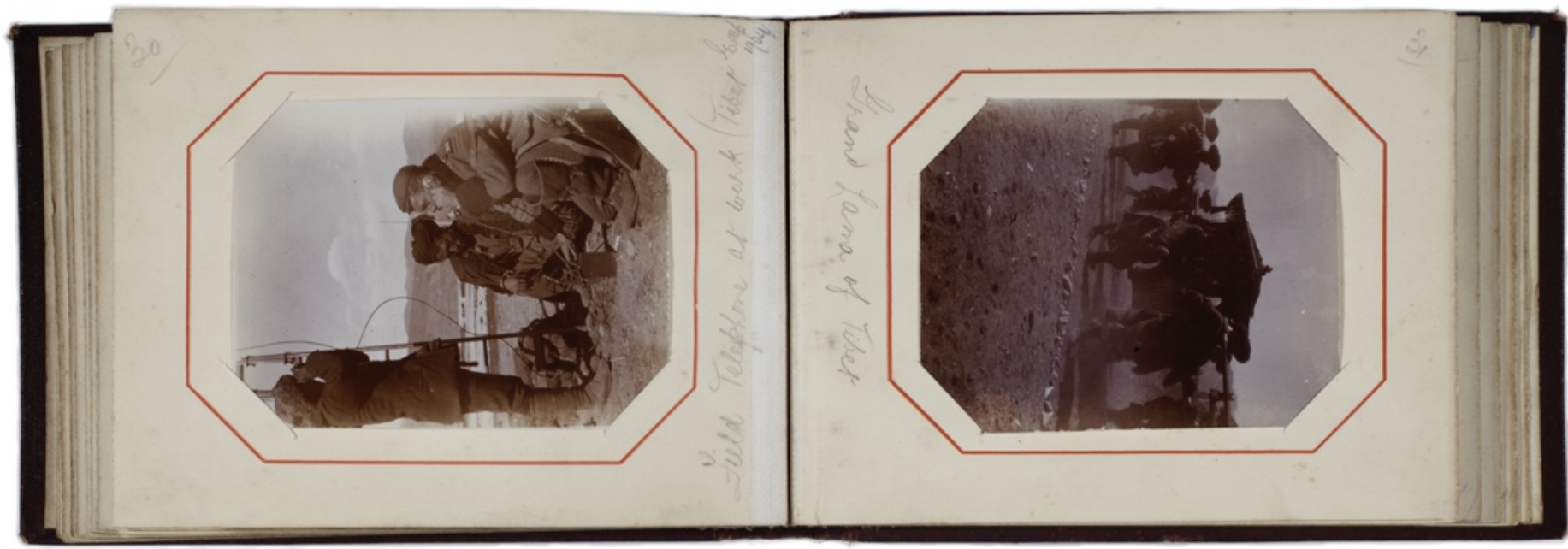

Caption Field Telephone at Work (Tibet Exp. 1904)

Photographer initialed W.C.

Date ca. 1903-1904

Medium Collodion silver print on printing-out paper.

Dimensions $10 \times 7 \mathrm{~cm}$

AMC 22680_1-34
Caption Grand Lama of Tibet

Photographer initialed W.C.

Date ca. 1903-1904

Medium Collodion silver print on printing-out paper.

Dimensions $10 \times 7 \mathrm{~cm}$

AMC 22680_1-35

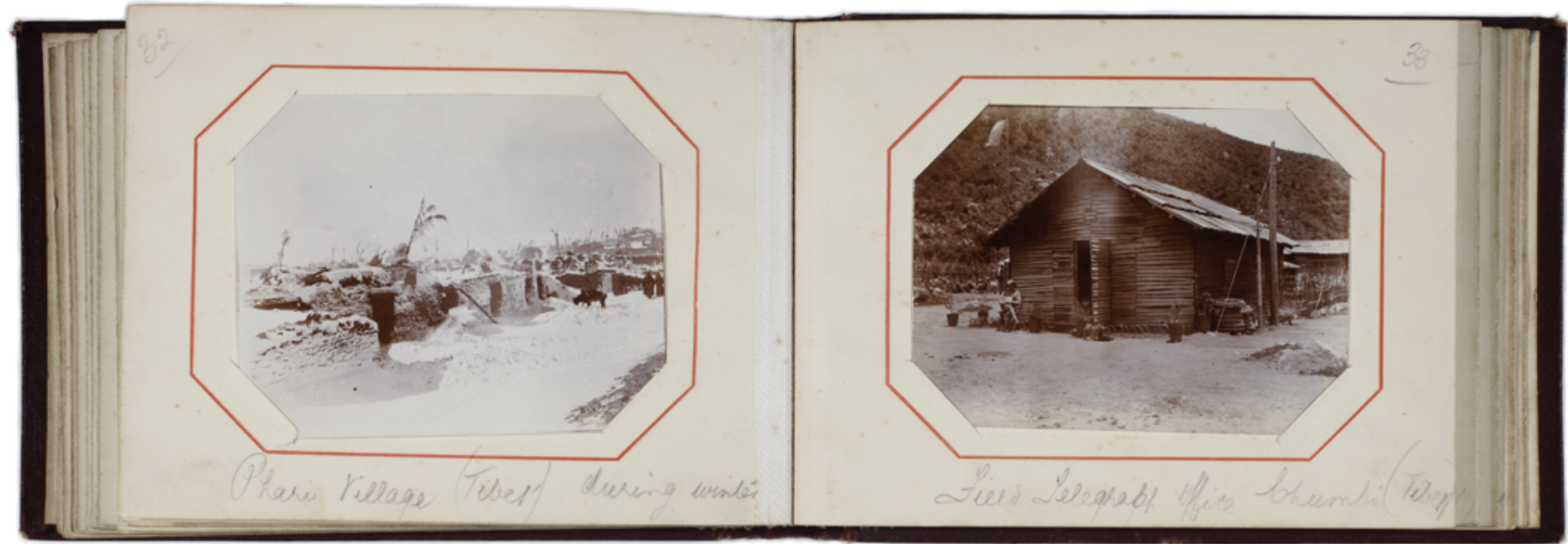

Gaption Phari Village (Tibet) during winter

Photographer initialed W.C.

Date ca. 1903-1904

Medium Collodion silver print on printing-out paper.

Dimensions 7 x $10 \mathrm{~cm}$

AMC 22680_1-36
Caption Field Telegraph of Chumbi (Tibet)

Photographer initialed W.C.

Date ca. 1903-1904

Medium Collodion silver print on printing-out paper.

Dimensions $10 \times 7 \mathrm{~cm}$

AMC 22680_1-37 


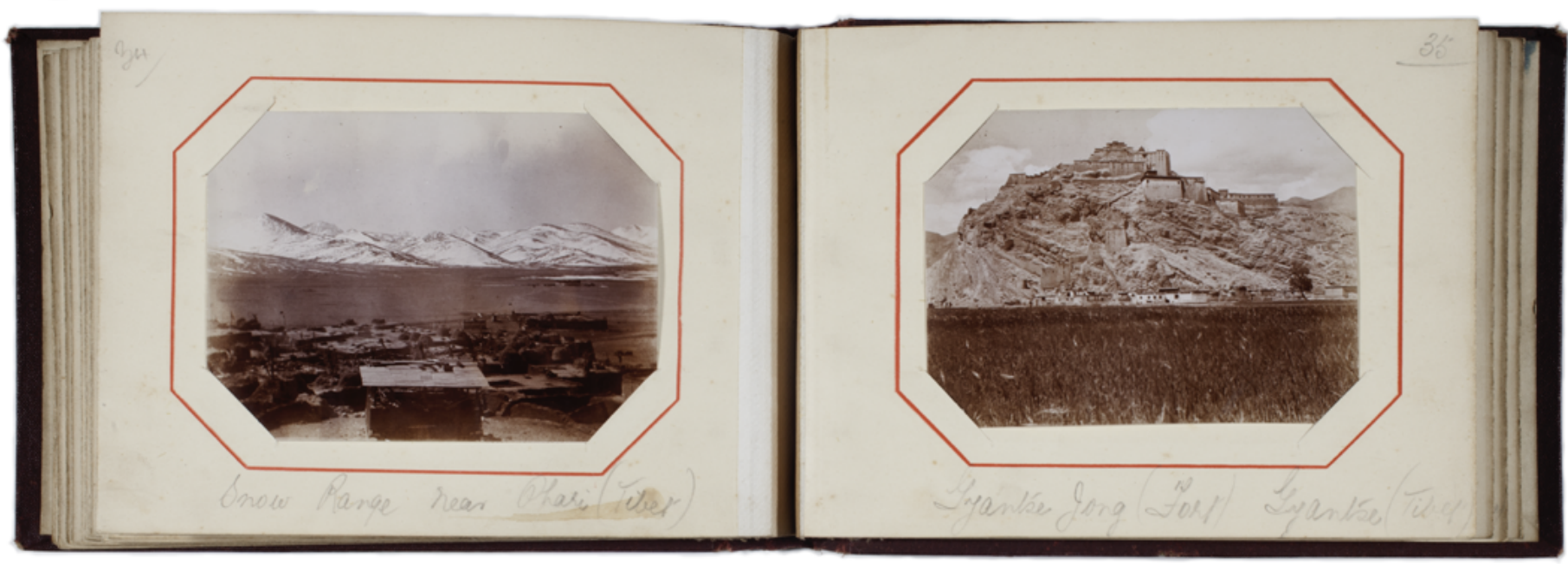

Gaption Snow Range Near Phari (Tibet)

Photographer initialed W.C.

Date ca. 1903-1904

Medium Collodion silver print on printing-out paper.

Dimensions 7 x $10 \mathrm{~cm}$

AMC 22680_1-38
Caption Gyantse Fong (Fort) Gyantse (Tibet)

Photographer initialed W.C.

Date ca. 1903-1904

Medium Collodion silver print on printing-out paper. Dimensions 7 x $10 \mathrm{~cm}$ AMC 22680_1-39

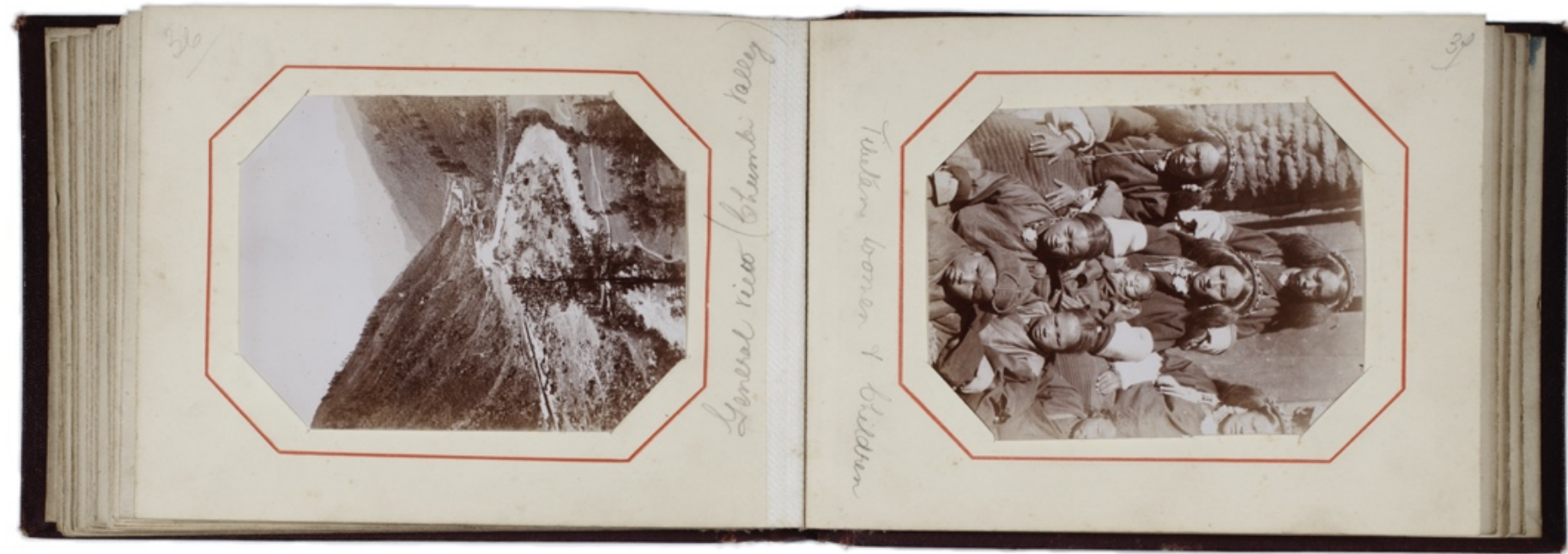

Gaption General view (Chumbi Valley)

Photographer initialed W.C.

Date ca. 1903-1904

Medium Collodion silver print on printing-out paper.

Dimensions $10 \times 7 \mathrm{~cm}$

AMC 22680_1-40
Caption Tibetan women + children

Photographer initialed W.C.

Date ca. 1903-1904

Medium Collodion silver print on printing-out paper.

Dimensions $10 \times 7 \mathrm{~cm}$

AMC 22680_1-41 


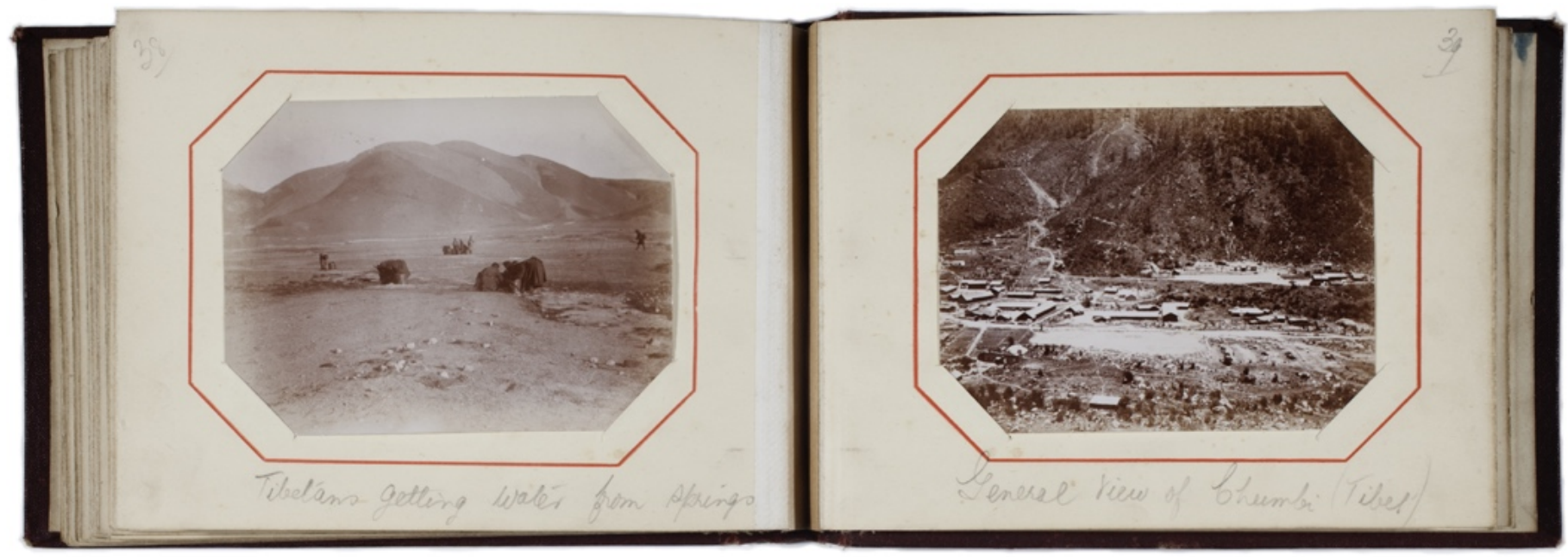

Gaption Tibetans getting water from springs

Photographer initialed W.C.

Date ca. 1903-1904

Medium Collodion silver print on printing-out paper.

Dimensions 7 x $10 \mathrm{~cm}$

AMC 22680_1-42
Gaption General View of Chumbi (Tibet)

Photographer initialed W.C.

Date ca. 1903-1904

Medium Collodion silver print on printing-out paper.

Dimensions 7 x $10 \mathrm{~cm}$

AMC 22680_1-43

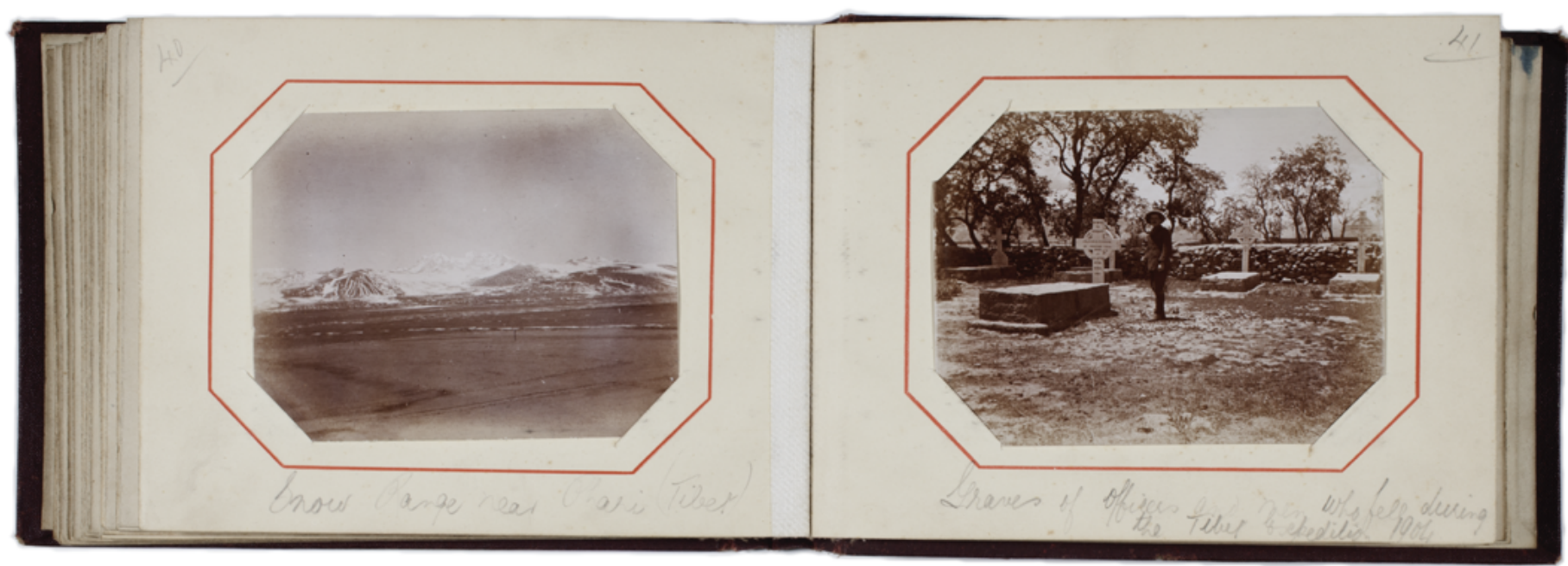

Gaption Snow Range near Phari (Tibet)

Photographer initialed W.C.

Date ca. 1903-1904

Medium Collodion silver print on printing-out paper.

Dimensions 7 x $10 \mathrm{~cm}$

AMC 22680_1-44
Caption Graves of officers and men who fell during the Tibet Expedition 1904

Photographer initialed W.C.

Date ca. 1903-1904

Medium Collodion silver print on printing-out paper. Dimensions $10 \times 7 \mathrm{~cm}$ AMC 22680_1-45 


\section{Appendix A Album from Tibet Expedition, 1904 Catalogue}

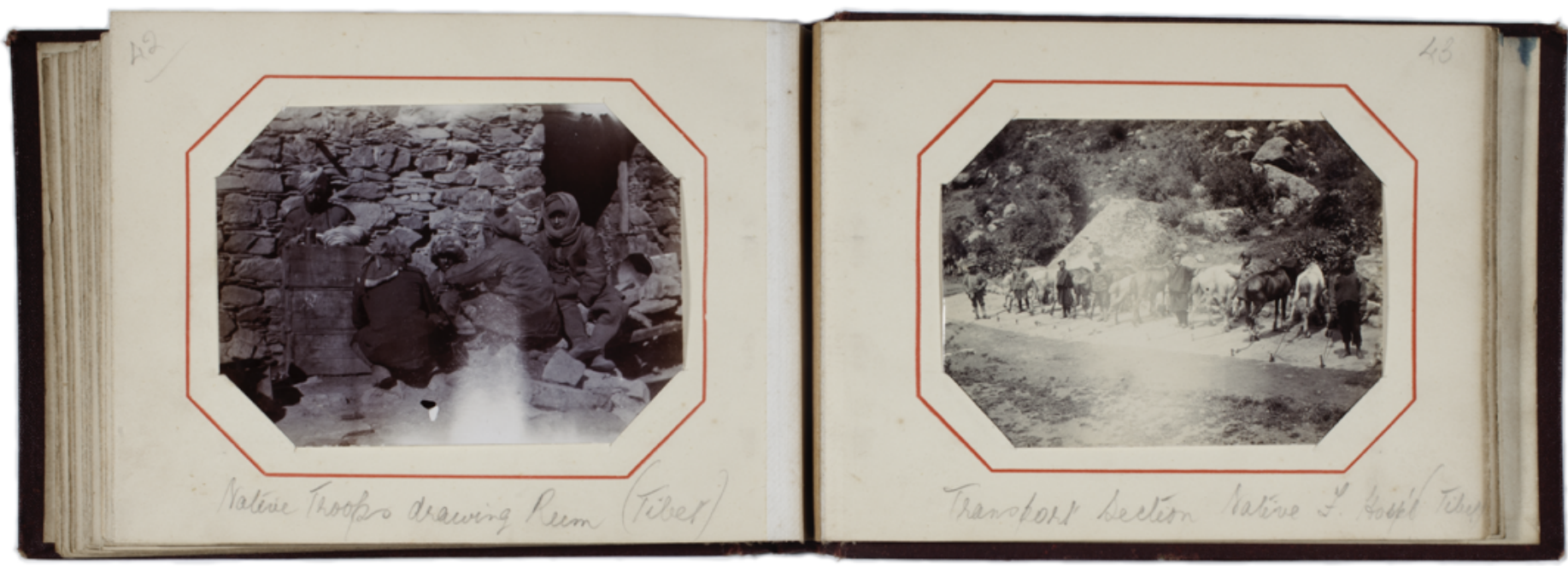

Gaption Native Troops drawing Rum (Tibet)

Photographer initialed W.C.

Date ca. 1903-1904

Medium Collodion silver print on printing-out paper.

Dimensions $7 \times 10 \mathrm{~cm}$

AMC 22680_1-46
Caption Transport section, Native F. Hosp'l (Tibet)

Photographer initialed W.C.

Date ca. 1903-1904

Medium Collodion silver print on printing-out paper. Dimensions 7 x $10 \mathrm{~cm}$

AMC 22680_1-47

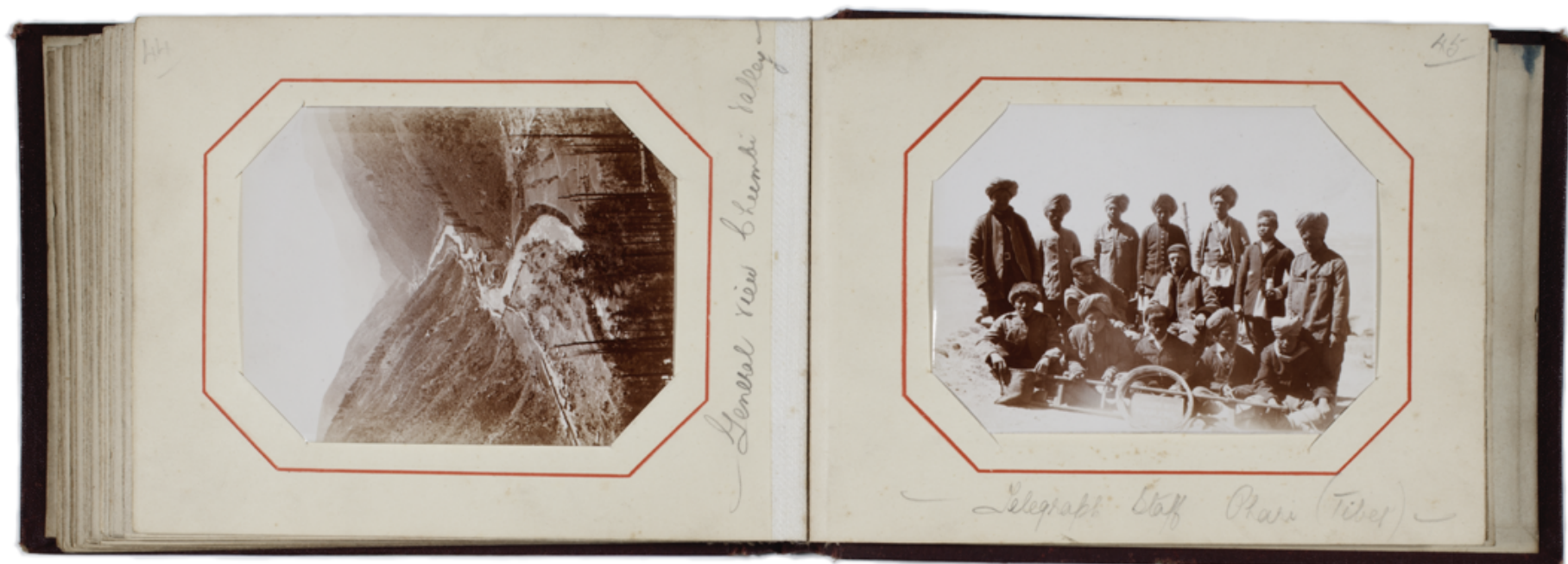

Caption General view Chumbi Valley

Photographer initialed W.C.

Date ca. 1903-1904

Medium Collodion silver print on printing-out paper.

Dimensions $10 \times 7 \mathrm{~cm}$

AMC 22680_1-48
Caption Telegraph Staff, Phari (Tibet)

Photographer initialed W.C.

Date ca. 1903-1904

Medium Collodion silver print on printing-out paper. Dimensions $7 \times 10 \mathrm{~cm}$ AMC 22680_1-49 


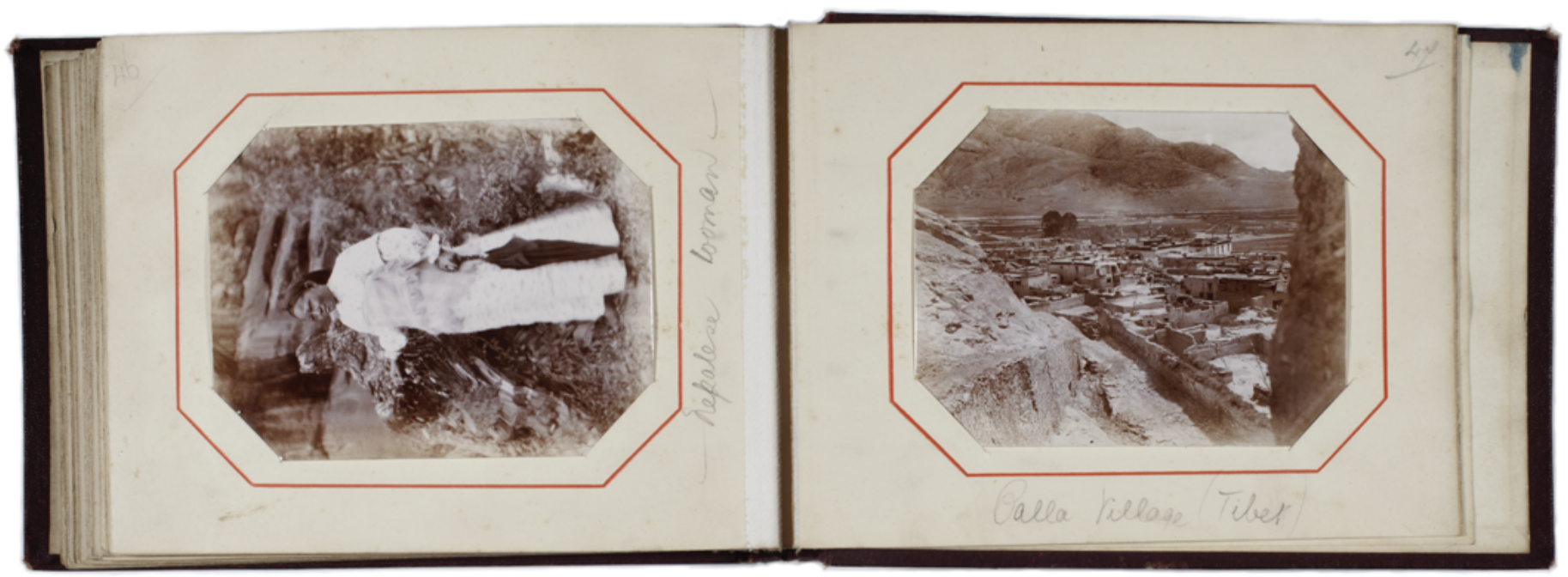

Caption Nepalese Woman

Photographer initialed W.C.

Date ca. 1903-1904

Medium Collodion silver print on printing-out paper.

Dimensions $10 \times 7 \mathrm{~cm}$

AMC 22680_1-50
Caption Palla Village (Tibet)

Photographer initialed W.C.

Date ca. 1903-1904

Medium Collodion silver print on printing-out paper. Dimensions $10 \times 7 \mathrm{~cm}$

AMC 22680_1-51

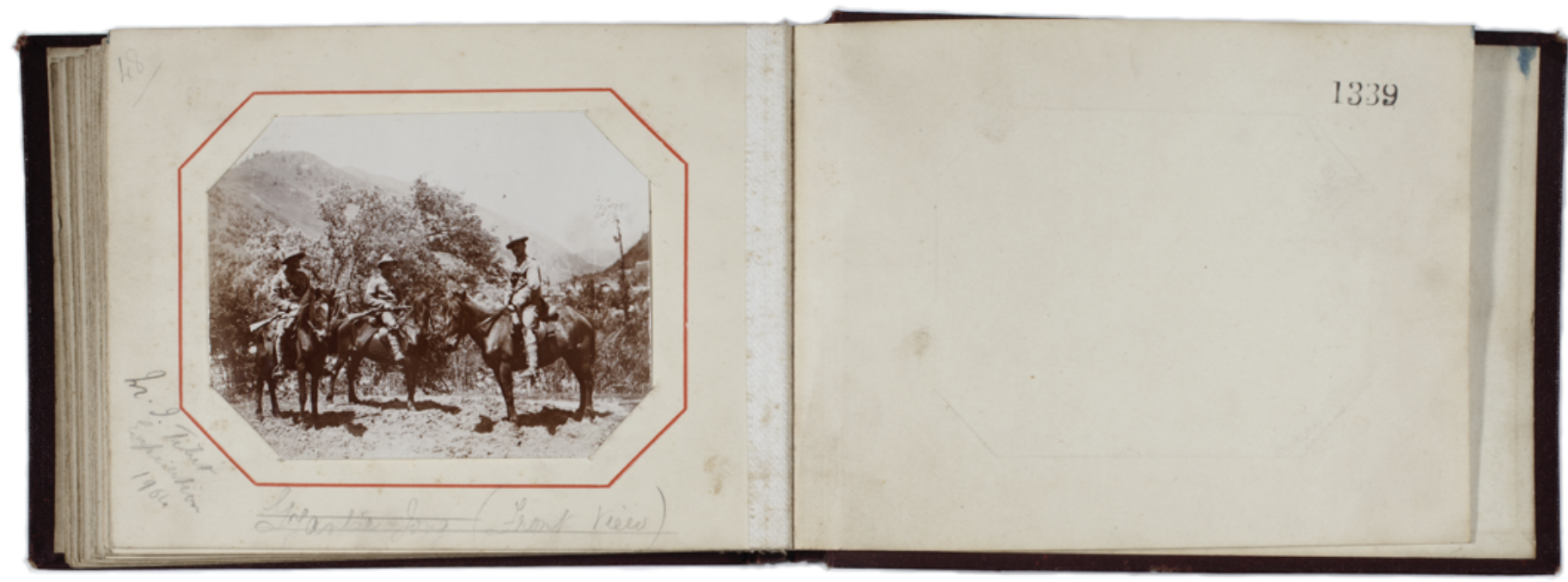

Caption M.I. Tibet Expedition 1904

Photographer initialed W.C.

Date ca. 1903-1904

Medium Collodion silver print on printing-out paper.

Dimensions $10 \times 7 \mathrm{~cm}$

AMC 22680_1-52
Description Recto back leaf.

AMC 22680_1-53 
Appendix A Album from Tibet Expedition, 1904 Catalogue

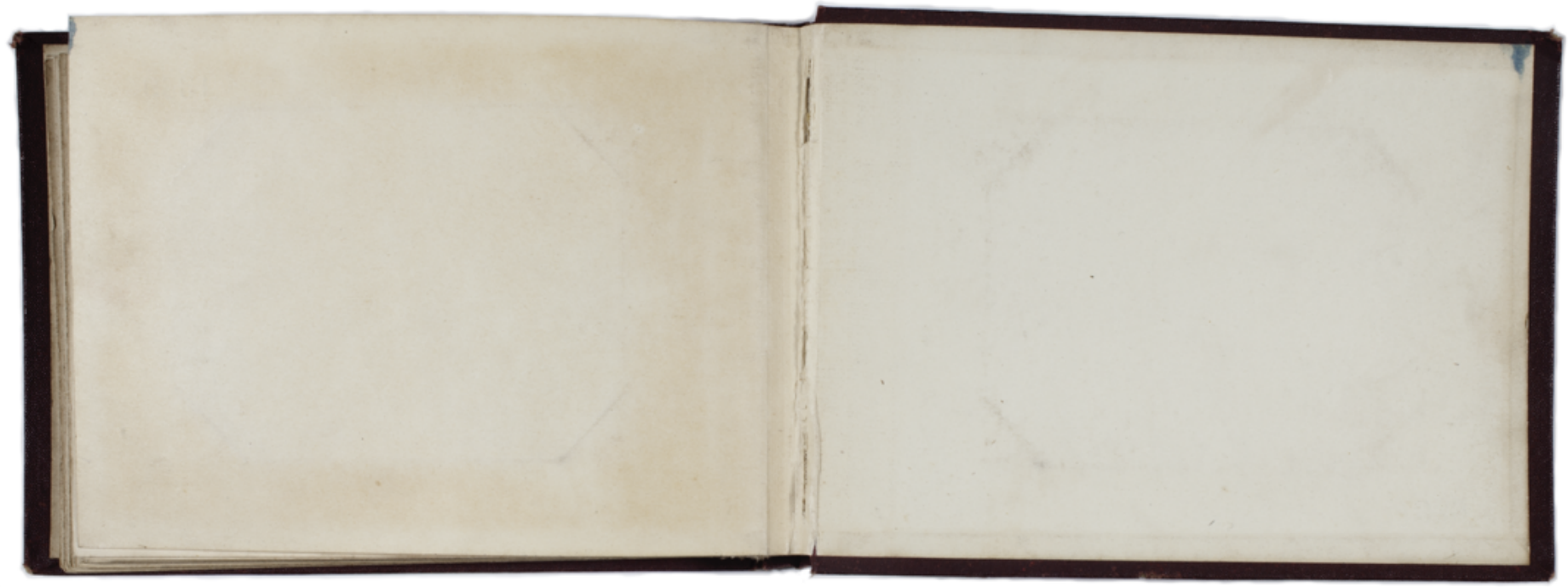

Description Verso back leaf.

AMC 22680_1-54
Description Inside back cover.

AMC 22680_1-55

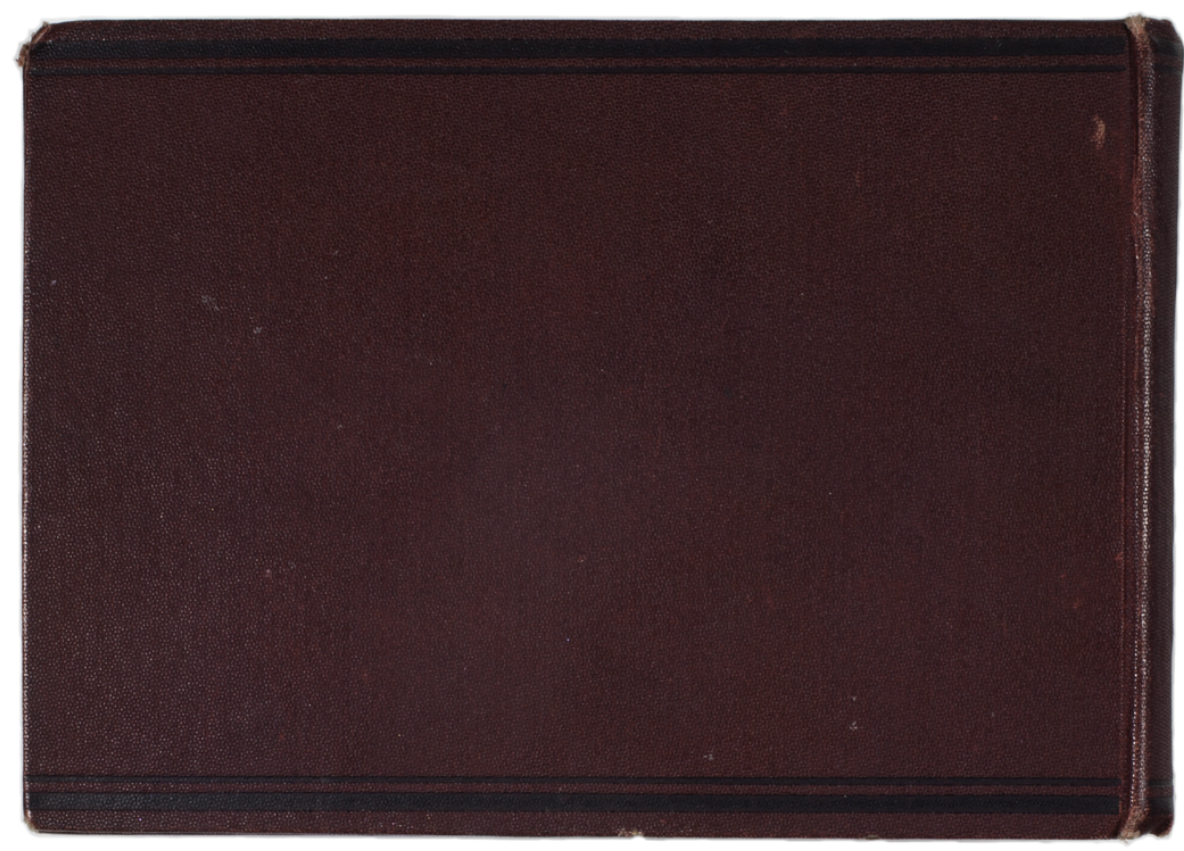

Description Back cover.

Dimensions $12.5 \times 17 \mathrm{~cm}(2.5 \mathrm{~cm}$ deep $)$

AMC 22680_1-56 
Appendix B Hayman Album Catalogue

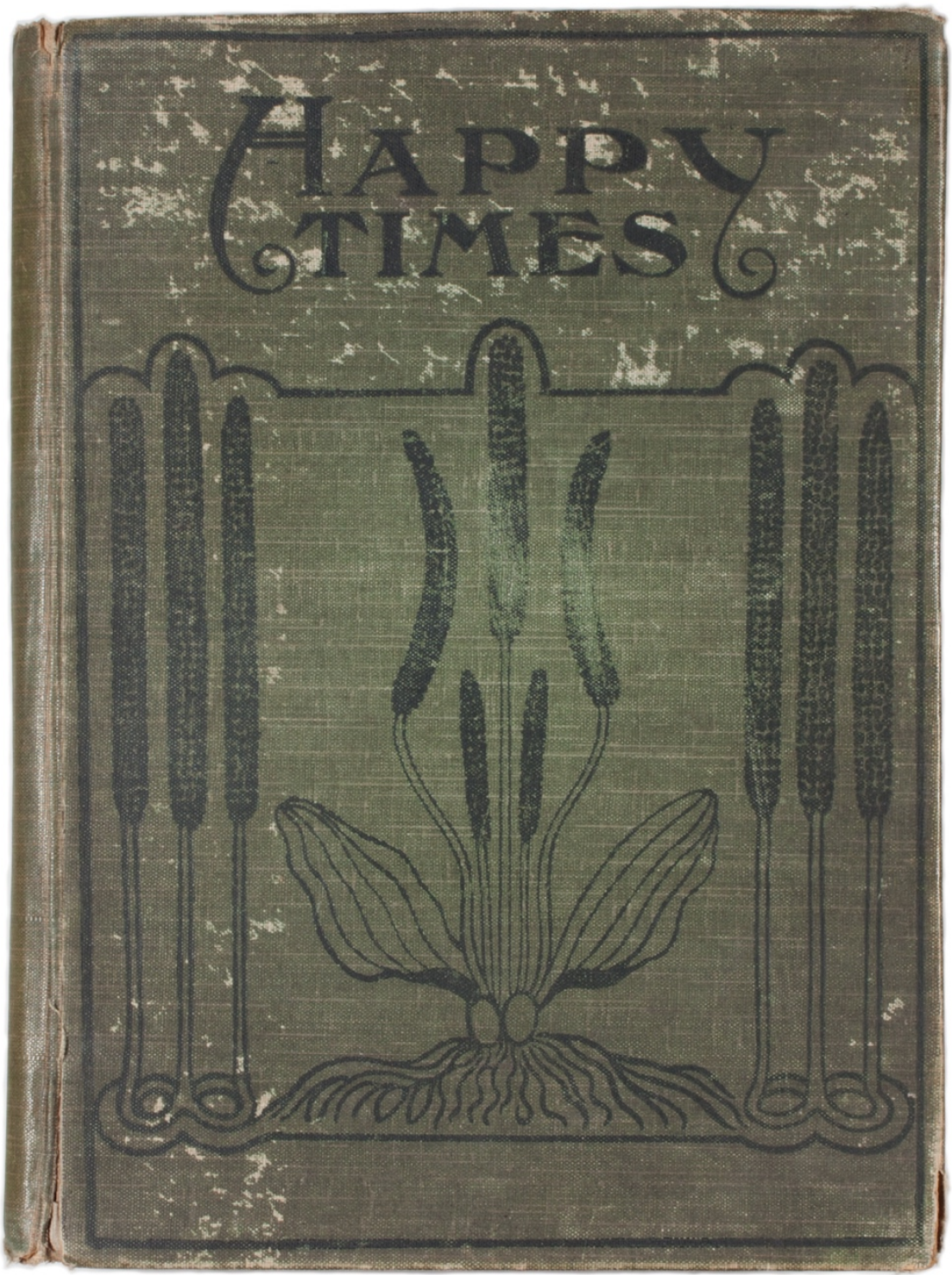

Description Front cover

Dimensions

AMC 24796_1 
Caption Teesta Bridge, Sikkim

Photographer initialed W.C.

Date ca. 1903-1904

Medium Collodion silver print on printing-out

paper.

Dimensions 7 x $10 \mathrm{~cm}$

AMC 24796_1-3-2

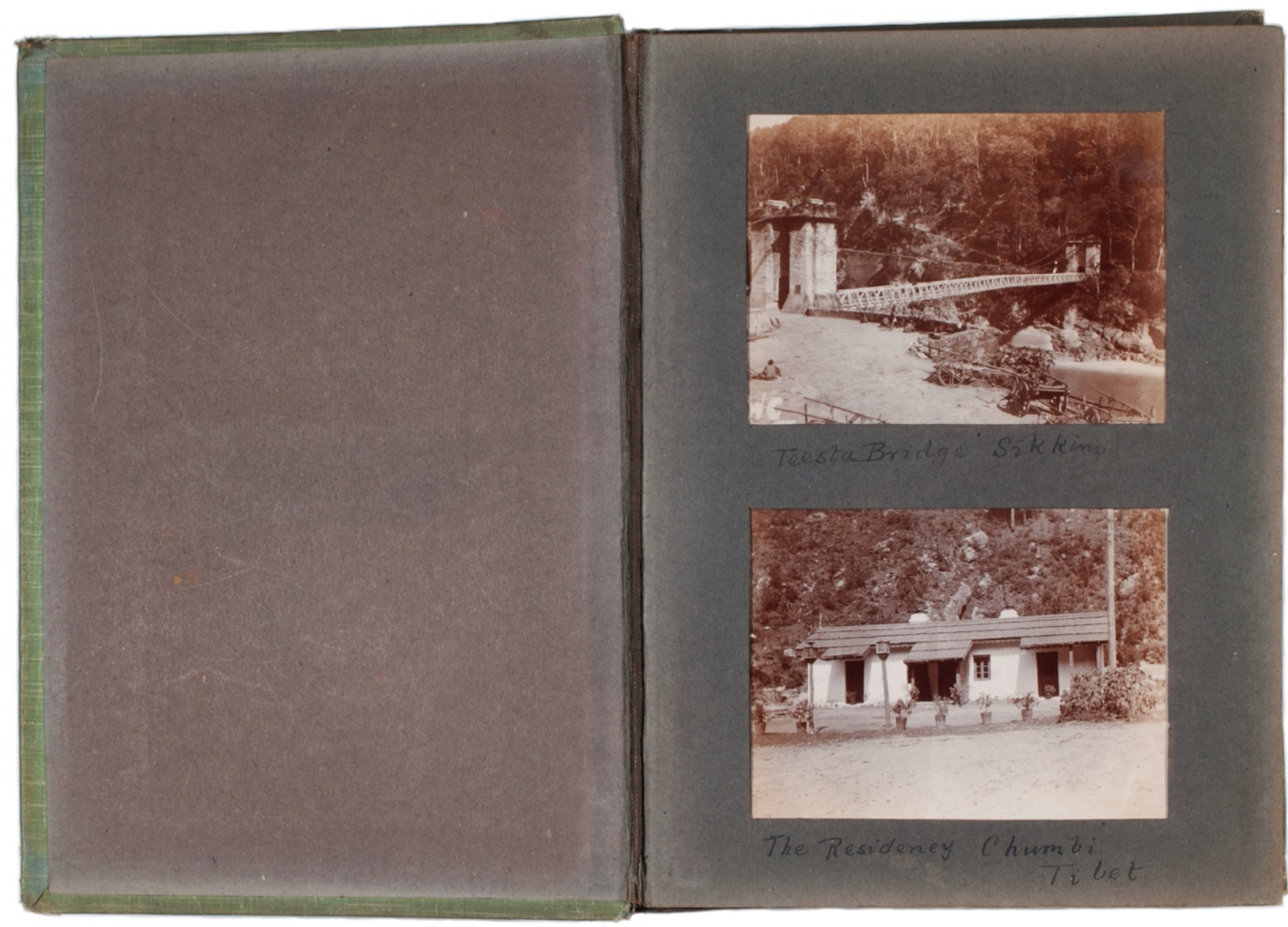

Description Inside front cover.

Dimensions

AMG 24796_1-2
Caption The Residency, Chumbi, Tibet

Photographer initialed W.C.

Date ca. 1903-1904

Medium Collodion silver print on printing-out paper.

Dimensions 7 x $10 \mathrm{~cm}$

AMC 24796_1-3-3 
Caption The Amo Cha River, Tibet

Photographer initialed W.C.

Date ca. 1903-1904

Medium Collodion silver print on printing-out paper.

Dimensions 7 x $10 \mathrm{~cm}$

AMC 24796_1-4-2
Caption Chumbi, Tibet

Photographer initialed W.C.

Date ca. 1903-1904

Medium Collodion silver print on printing-out paper.

Dimensions 7 × $10 \mathrm{~cm}$

AMC 24796_1-5-2

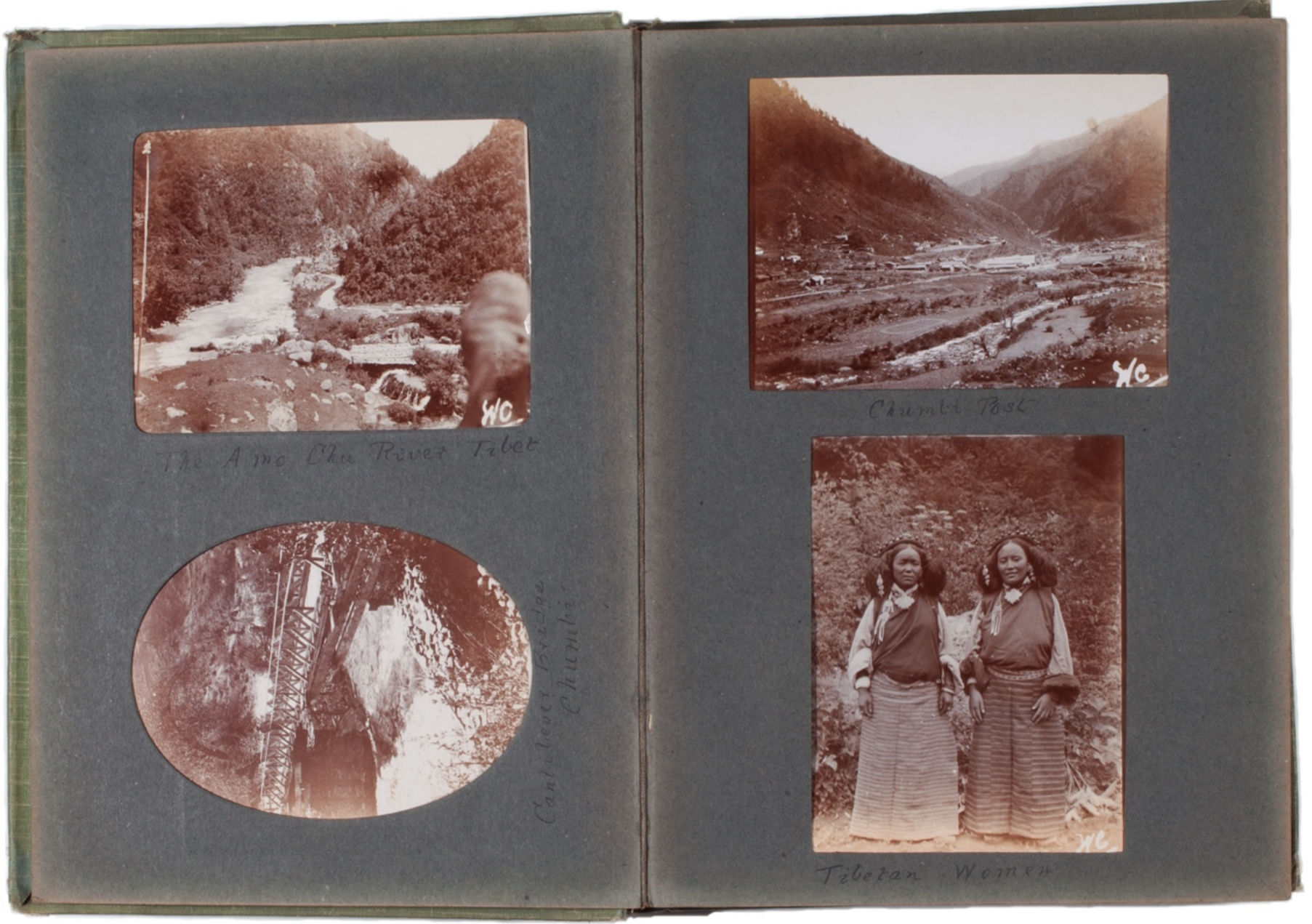

Caption Cantilever Bridge, Chumbi

Photographer initialed W.C.

Date ca. 1903-1904

Medium Collodion silver print on printing-out paper.

Dimensions $10 \times 7 \mathrm{~cm}$

AMC 24796_1-4-3
Caption Tibetan Women

Photographer initialed W.C.

Date ca. 1903-1904

Medium Collodion silver print on printing-out paper.

Dimensions $10 \times 7 \mathrm{~cm}$ AMC 24796_1-5-3 
Caption Tibetan Urchins

Photographer initialed W.C.

Date ca. 1903-1904

Medium Collodion silver print on printing-out paper.

Dimensions 7 × $10 \mathrm{~cm}$

AMC 24796_1-6-2
Caption Phari Village in winter (looking North)

Photographer initialed W.C.

Date ca. 1903-1904

Medium Collodion silver print on printing-out paper.

Dimensions 7 × $10 \mathrm{~cm}$

AMC 24796_1-7-2
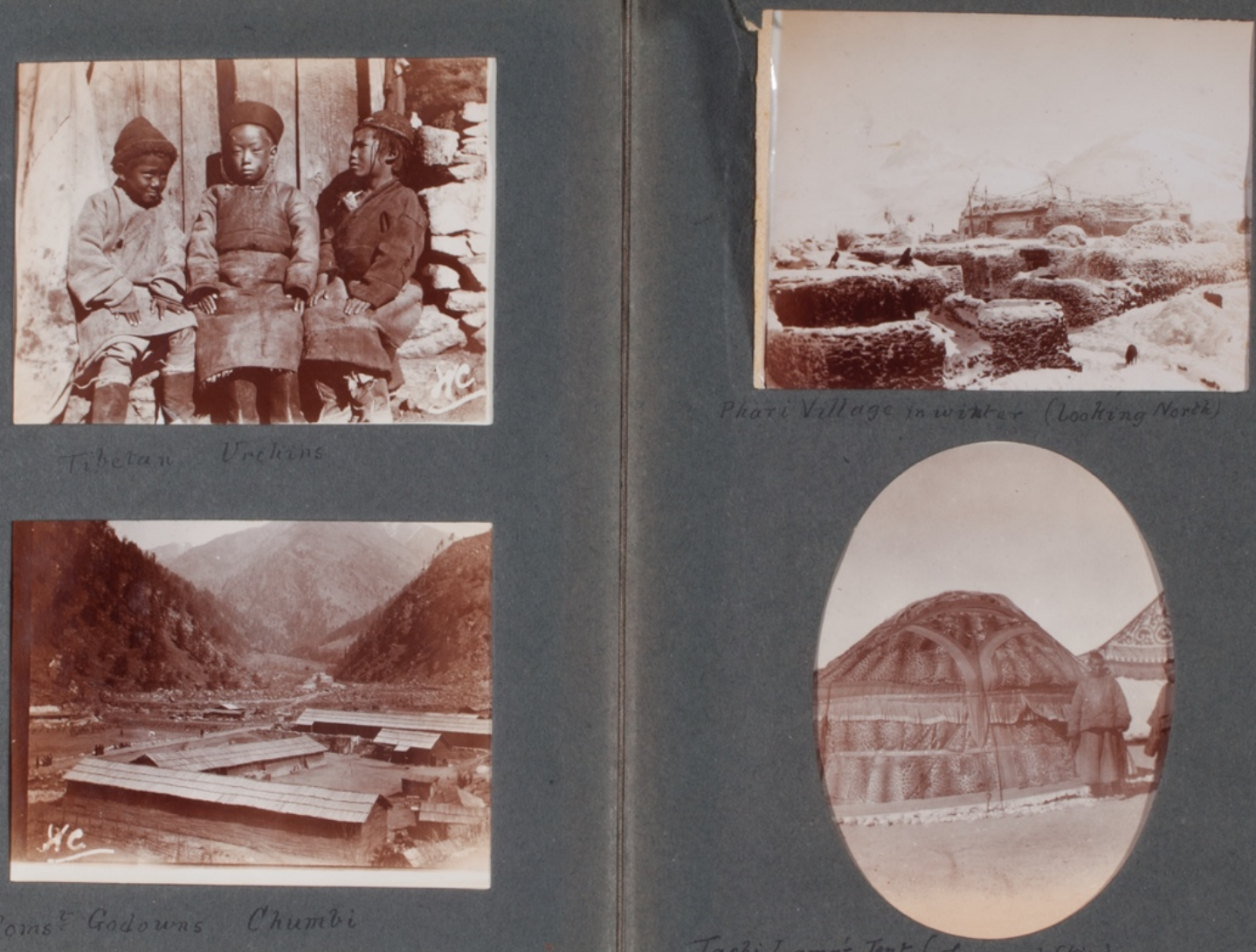

Caption Coms't [Commissariat]Godowns, Chumbi

Photographer initialed W.C.

Date ca. 1903-1904

Medium Collodion silver print on printing-out paper.

Dimensions $7 \times 10 \mathrm{~cm}$

AMC 24796_1-6-3
Caption Tashi Lama's Tent (Leopard Skin)

Photographer initialed W.C.

Date ca. 1903-1904

Medium Collodion silver print on printing-out paper.

Dimensions $10 \times 7 \mathrm{~cm}$

AMC 24796_1-7-3 
Caption Phema Village (Tibet_

Photographer initialed W.C.

Date ca. 1903-1904

Medium Collodion silver print on printing-out paper.

Dimensions 7 × $10 \mathrm{~cm}$

AMC 24796_1-8-2
Caption Field Telegraph Office (Phari)

Photographer initialed W.C.

Date ca. 1903-1904

Medium Collodion silver print on printing-out paper.

Dimensions 7 × $10 \mathrm{~cm}$

AMC 24796_1-9-2

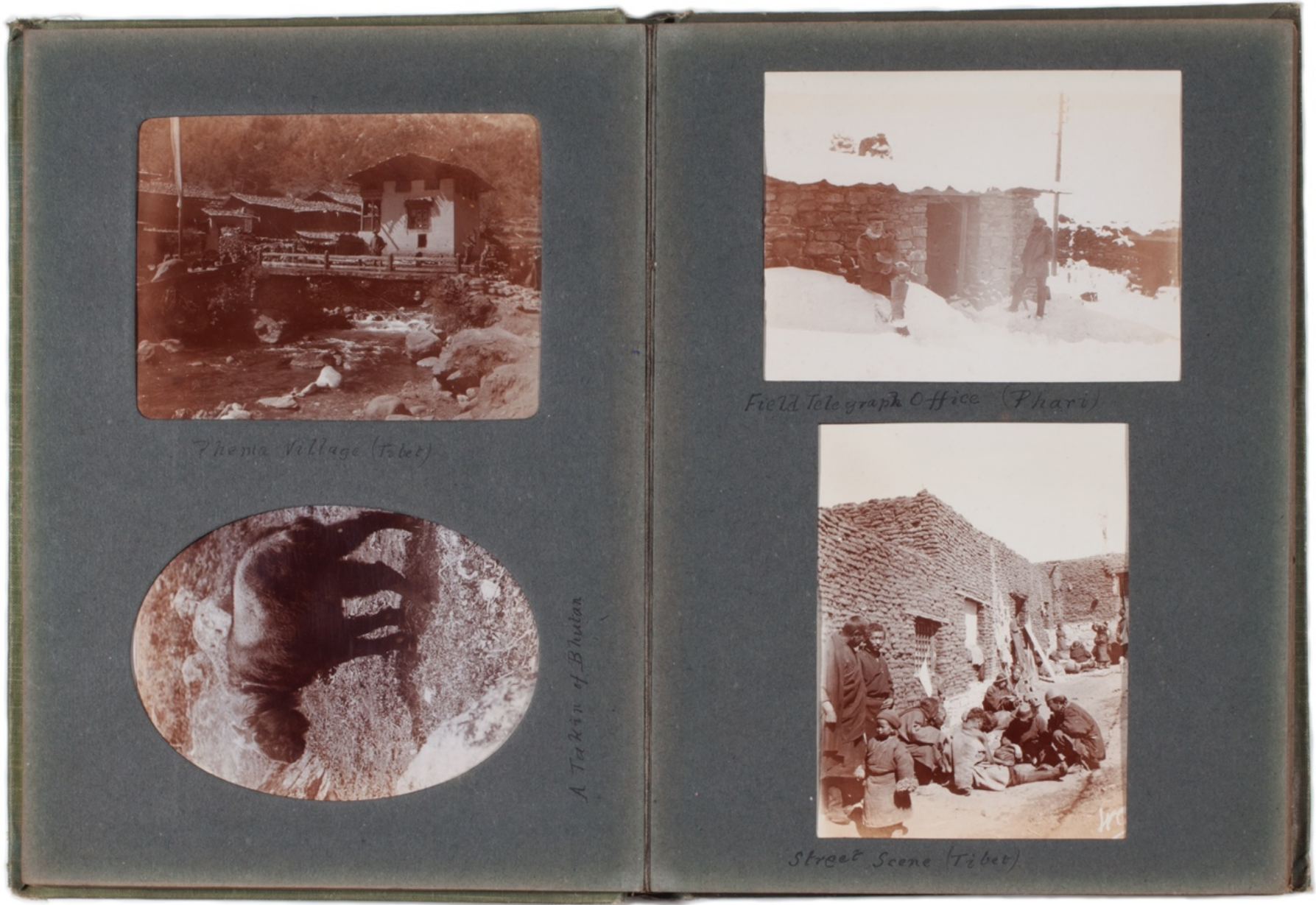

Caption $A$ Takin of Bhutan

Photographer initialed W.C.

Date ca. 1903-1904

Medium Collodion silver print on printing-out paper.

Dimensions $10 \times 7 \mathrm{~cm}$

AMC 24796_1-8-3
Caption Street Scene (Tibet)

Photographer initialed W.C.

Date ca. 1903-1904

Medium Collodion silver print on printing-out paper.

Dimensions $10 \times 7 \mathrm{~cm}$

AMC 24796_1-9-3 
Caption A Group of Tibetans

Photographer initialed W.C.

Date ca. 1903-1904

Medium Collodion silver print on printing-out paper.

Dimensions 7 × $10 \mathrm{~cm}$

AMC 24796_1-10-2
Caption Gyantse Fong Fort (from the East)

Photographer initialed W.C.

Date ca. 1903-1904

Medium Collodion silver print on printing-out paper.

Dimensions 7 × $10 \mathrm{~cm}$

AMC 24796_1-11-2
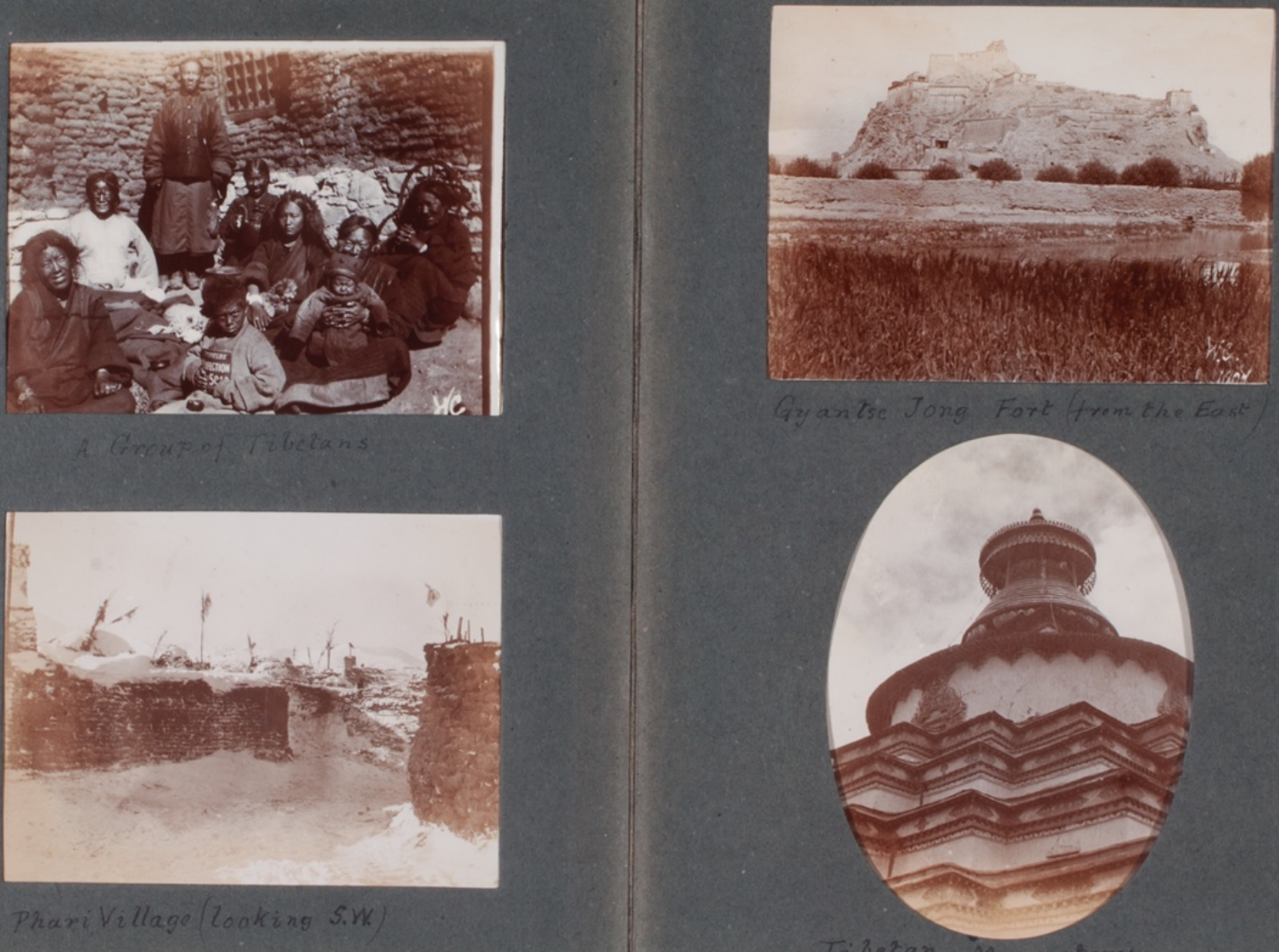

Caption Phari Village (looking S.W.)

Photographer initialed W.C.

Date ca. 1903-1904

Medium Collodion silver print on printing-out paper.

Dimensions $7 \times 10 \mathrm{~cm}$

AMC 24796_1-10-3
Caption Tibetan Monastery

Photographer initialed W.C.

Date ca. 1903-1904

Medium Collodion silver print on printing-out paper.

Dimensions $10 \times 7 \mathrm{~cm}$

AMC 24796_1-11-3 
Caption Ruins of Phari fong

Photographer initialed W.C.

Date ca. 1903-1904

Medium Collodion silver print on printing-out paper.

Dimensions 7 × $10 \mathrm{~cm}$

AMC 24796_1-12-2
Caption Tibetans Holiday Making

Photographer initialed W.C.

Date ca. 1903-1904

Medium Collodion silver print on printing-out paper.

Dimensions 7 x $10 \mathrm{~cm}$

AMC 24796_1-13-2

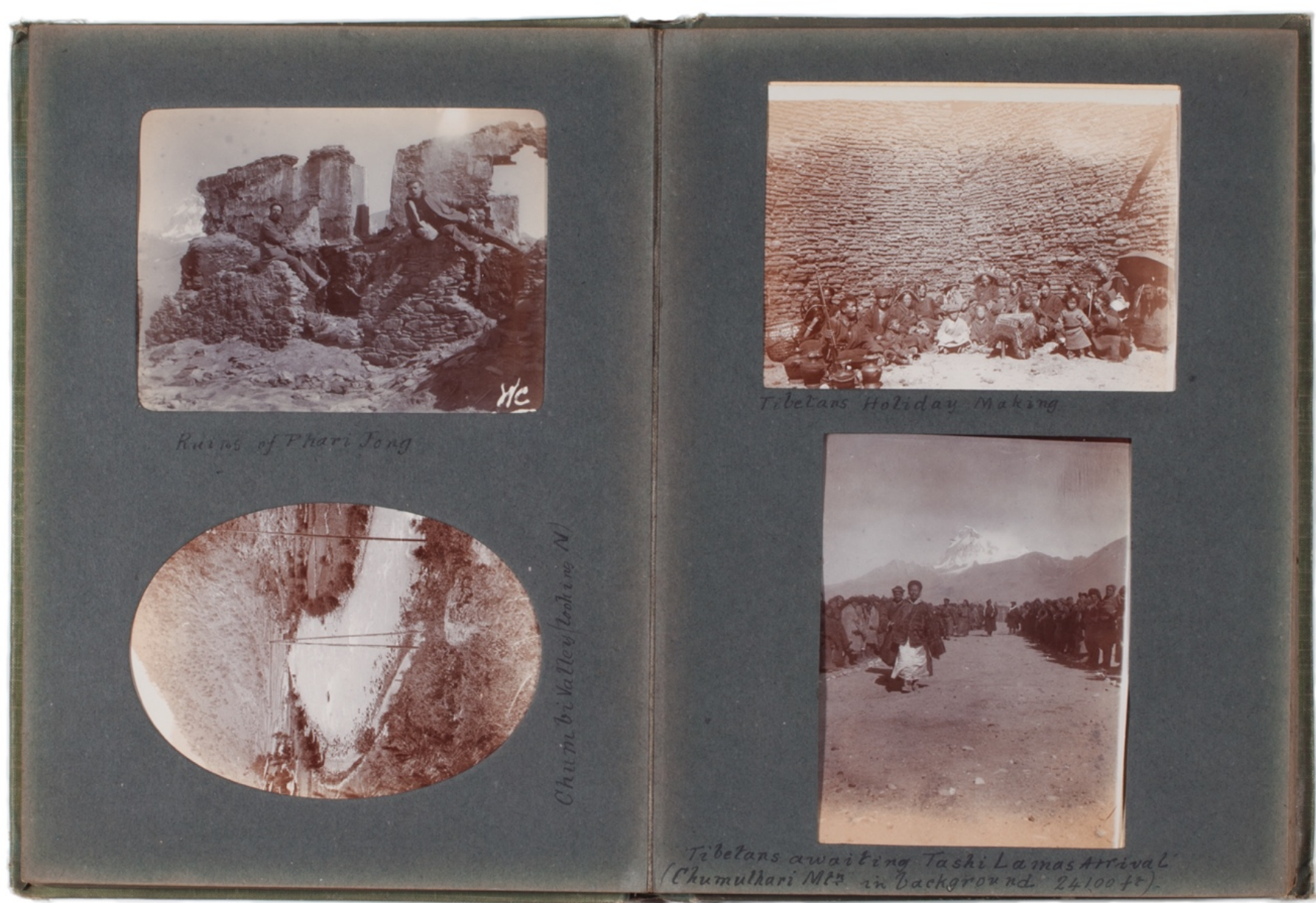

Caption Chumbi Valley (looking $\mathcal{N}$ )

Photographer initialed W.C.

Date ca. 1903-1904

Medium Collodion silver print on printing-out paper.

Dimensions $10 \times 7 \mathrm{~cm}$

AMG 24796_1-12-3
Caption Tibetans awaiting Tash Lama's arrival

(Chumulhari Mtn in background, $24100 \mathrm{ft}$ )

Photographer initialed W.C.

Date ca. 1903-1904

Medium Collodion silver print on printing-out paper.

Dimensions $10 \times 7 \mathrm{~cm}$

AMC 24796_1-13-3 
Caption Transport, Native Field Hospital

Photographer initialed W.C.

Date ca. 1903-1904

Medium Collodion silver print on printing-out paper.

Dimensions $7 \times 10 \mathrm{~cm}$

AMC 24796_1-14-2
Caption $Y u$ Sa Village (Tibet)

Photographer initialed W.C.

Date ca. 1903-1904

Medium Collodion silver print on printing-out paper.

Dimensions $7 \times 10 \mathrm{~cm}$

AMC 24796_1-15-2
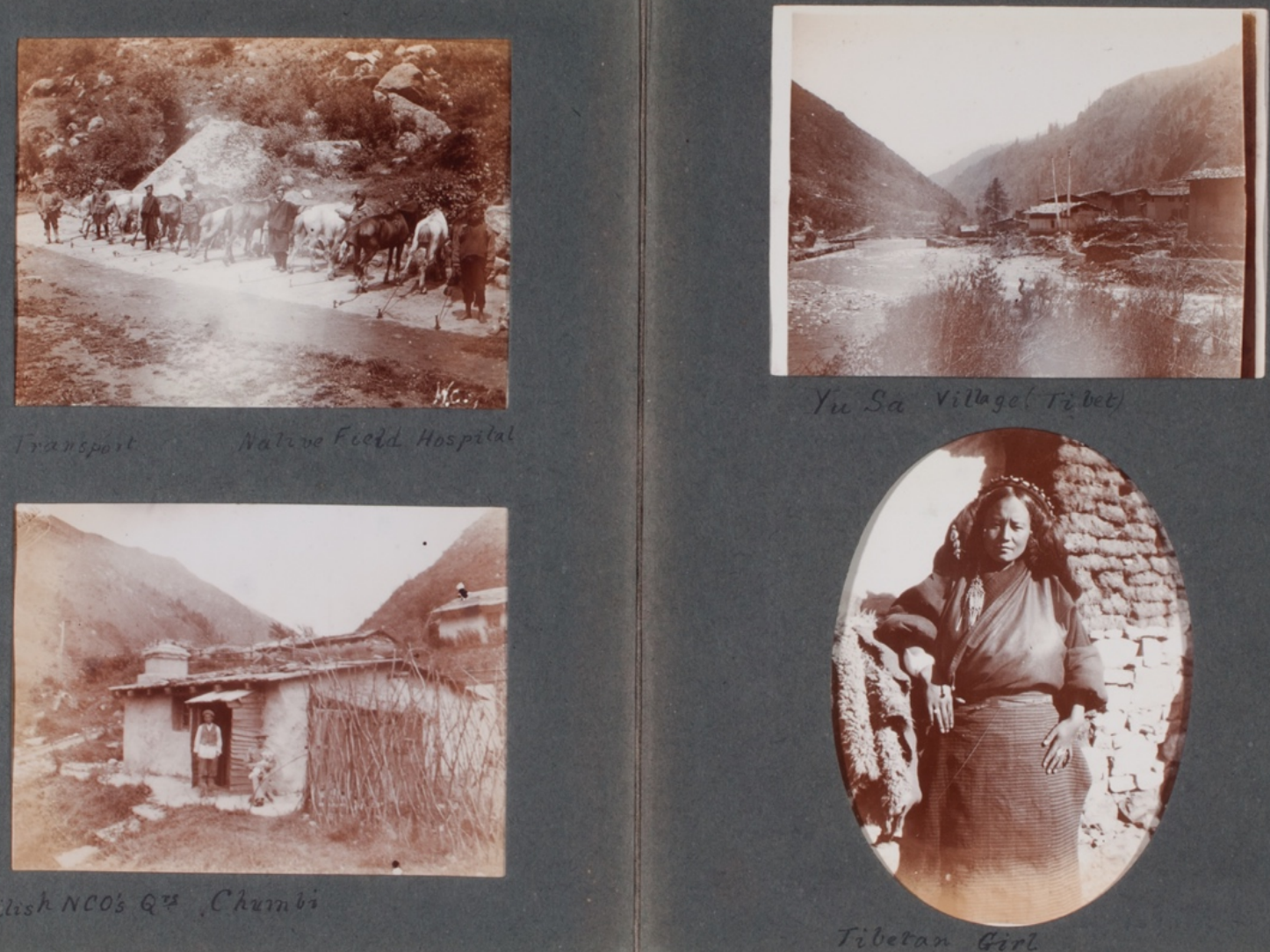

Caption British NCO's Ors [Quarters], Chumbi Photographer initialed W.C.

Date ca. 1903-1904

Medium Collodion silver print on printing-out paper.

Dimensions $7 \times 10 \mathrm{~cm}$

AMC 24796_1-14-3
Gaption Tibetan Girl

Photographer initialed W.C.

Date ca. 1903-1904

Medium Collodion silver print on printing-out paper.

Dimensions $10 \times 7 \mathrm{~cm}$

AMC 24796_1-15-3 
Caption Field Telegraph at Work (Tibetan Expedition 1904)

Photographer initialed W.C.

Date ca. 1903-1904

Medium Collodion silver print on printing-out paper.

Dimensions 7 × $10 \mathrm{~cm}$

AMC 24796_1-16-2
Caption Palla Village (from Gyantse fong)

Photographer initialed W.C.

Date ca. 1903-1904

Medium Collodion silver print on printing-out paper.

Dimensions $7 \times 10 \mathrm{~cm}$

AMC 24796_1-17-2

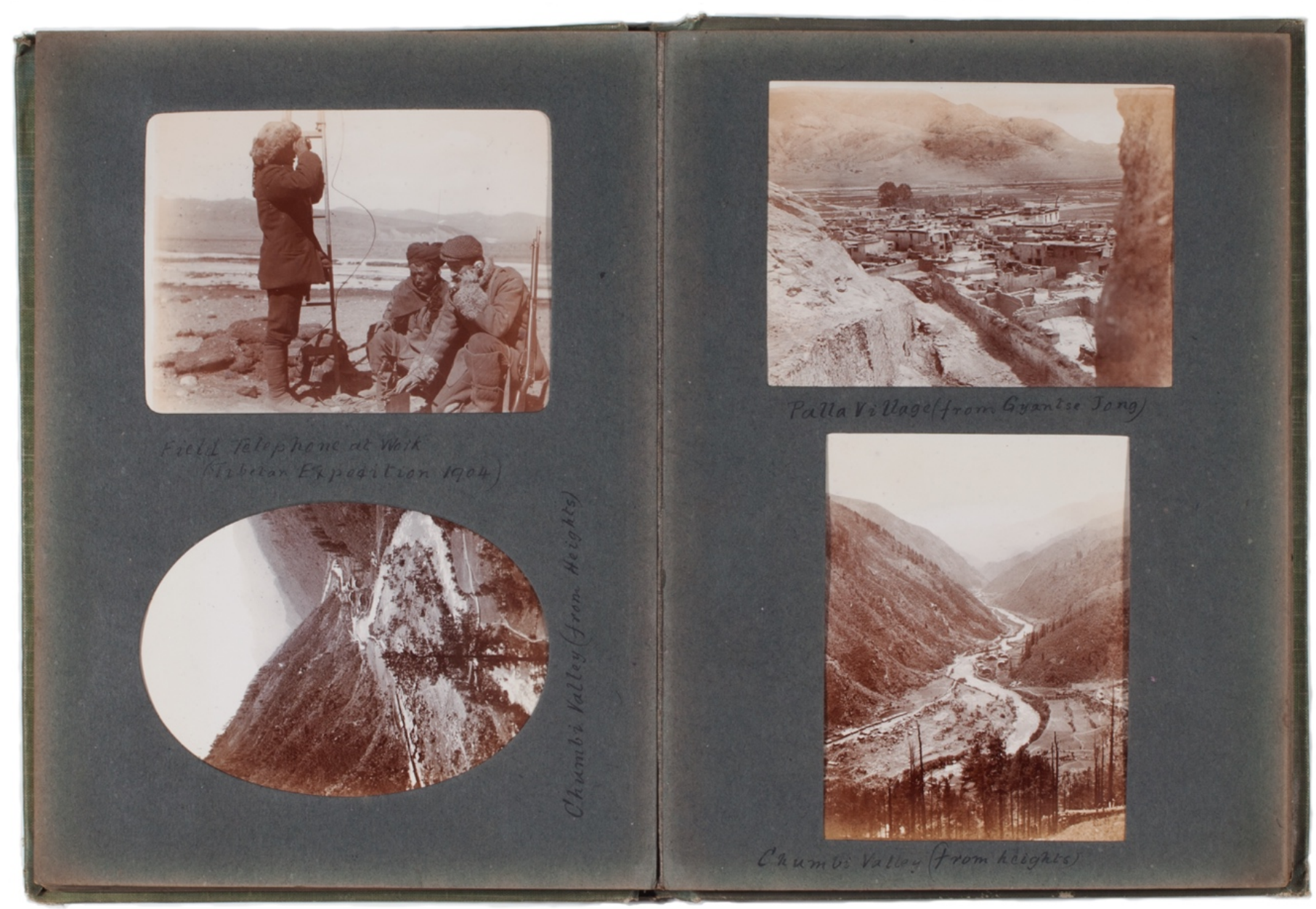

Caption Chumbi Valley (from Heights)

Photographer initialed W.C.

Date ca. 1903-1904

Medium Collodion silver print on printing-out paper.

Dimensions $10 \times 7 \mathrm{~cm}$

AMC 24796_1-16-3
Caption Chumbi Valley (from heights)

Photographer initialed W.C.

Date ca. 1903-1904

Medium Collodion silver print on printing-out paper.

Dimensions 7 × $10 \mathrm{~cm}$

AMC 24796_1-17-3 
Caption Bazaar at Phari

Photographer initialed W.C.

Date ca. 1903-1904

Medium Collodion silver print on printing-out paper.

Dimensions 7 x $10 \mathrm{~cm}$

AMC 24796_1-18-2
Caption Telegraph Staff, Phari

Photographer initialed W.C.

Date ca. 1903-1904

Medium Collodion silver print on printing-out paper.

Dimensions 7 x $10 \mathrm{~cm}$

AMC 24796_1-19-2

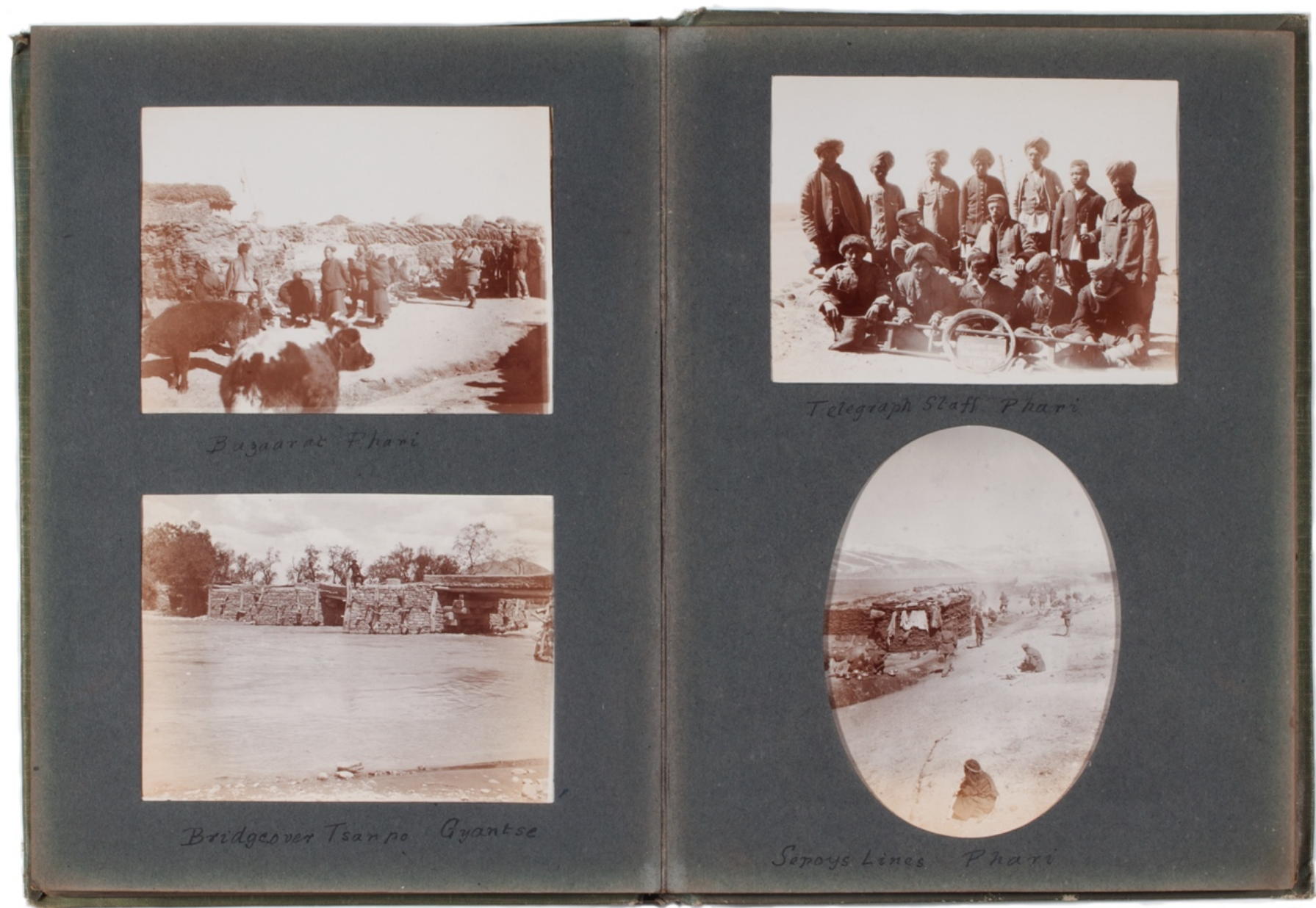

Caption Bridges over Tsanpo, Gyantse

Photographer initialed W.C.

Date ca. 1903-1904

Medium Collodion silver print on printing-out paper.

Dimensions $7 \times 10 \mathrm{~cm}$

AMC 24796_1-18-3
Caption Sepoys Lines, Phari

Photographer initialed W.C.

Date ca. 1903-1904

Medium Collodion silver print on printing-out paper.

Dimensions $10 \times 7 \mathrm{~cm}$

AMC 24796_1-19-3 
Caption Taks slaughtered for food for British Troops (Tibet) Photographer initialed W.C.

Date ca. 1903-1904

Medium Collodion silver print on printing-out paper.

Dimensions 7 x $10 \mathrm{~cm}$

AMC 24796_1-20-2

\author{
Caption Gyantse fong (front view) \\ Photographer initialed W.C. \\ Date ca. 1903-1904 \\ Medium Collodion silver print on printing-out \\ paper. \\ Dimensions 7 x $10 \mathrm{~cm}$ \\ AMC 24796_1-21-2
}

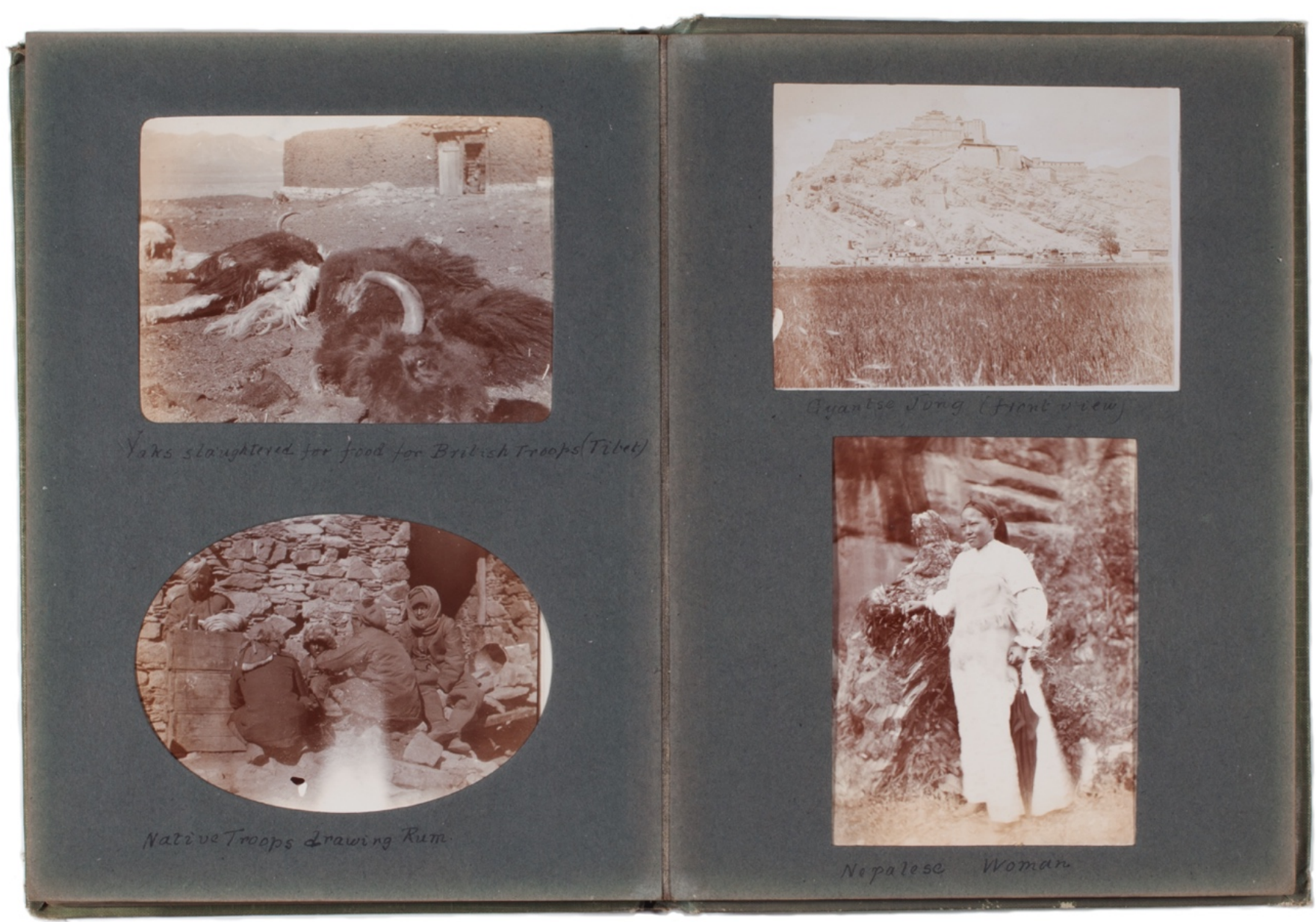

Caption Native Troops drawing Rum

Photographer initialed W.C.

Date ca. 1903-1904

Medium Collodion silver print on printing-out paper.

Dimensions 7 x $10 \mathrm{~cm}$

AMC 24796_1-20-3
Caption Nepalese Woman

Photographer initialed W.C.

Date ca. 1903-1904

Medium Collodion silver print on printing-out paper.

Dimensions $10 \times 7 \mathrm{~cm}$

AMC 24796_1-21-3 
Caption Phari Village (from fong)

Photographer initialed W.C.

Date ca. 1903-1904

Medium Collodion silver print on printing-out paper.

Dimensions 7 × $10 \mathrm{~cm}$

AMC 24796_1-22-2
Caption M.I. Reconnoit[e]ring (Tibet Expedition)

Photographer initialed W.C.

Date ca. 1903-1904

Medium Collodion silver print on printing-out paper.

Dimensions 7 x $10 \mathrm{~cm}$

AMC 24796_1-23-2
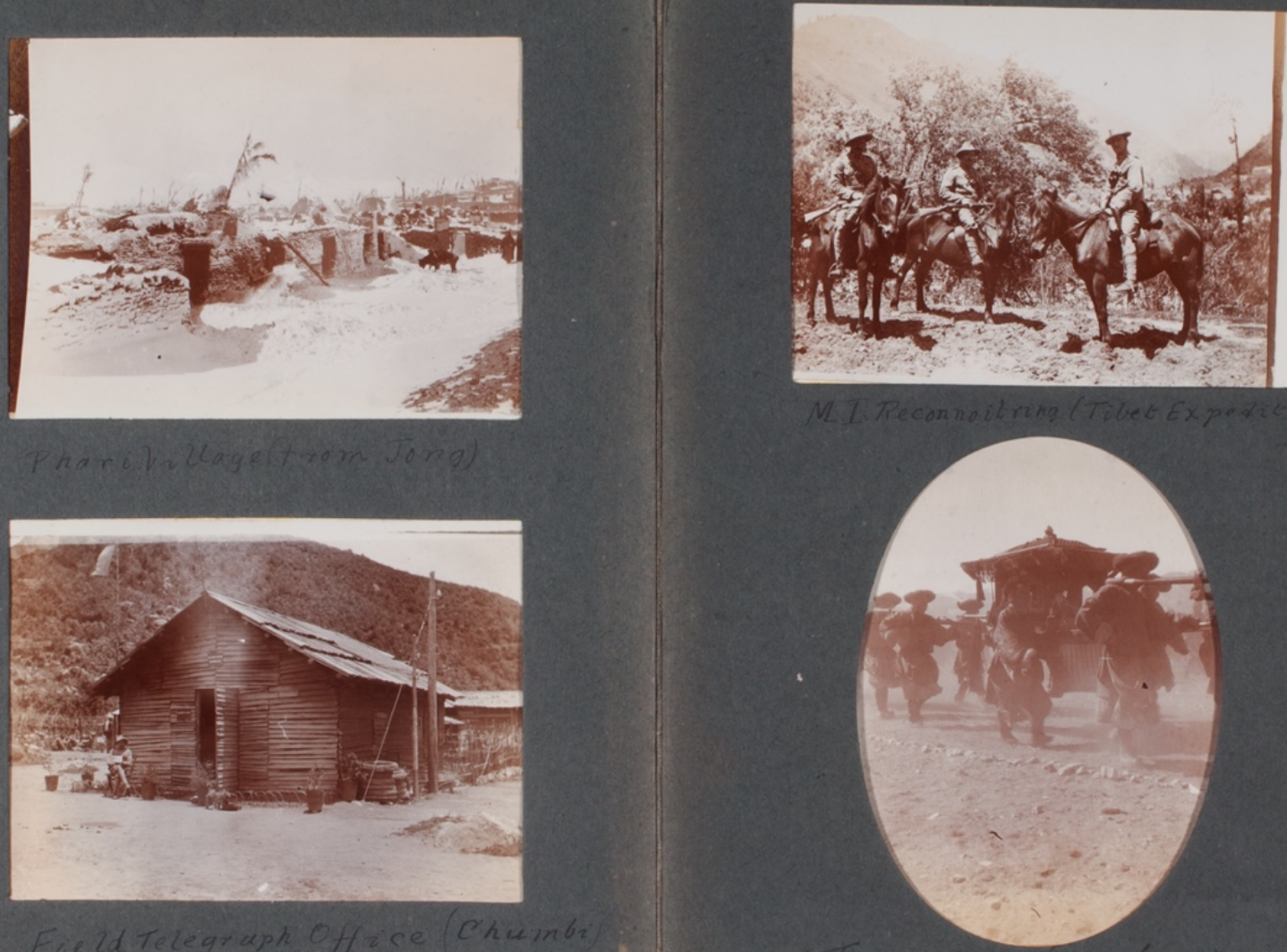

Gaption Field Telegraph Office (Chumbi)

Photographer initialed W.C.

Date ca. 1903-1904

Medium Collodion silver print on printing-out paper.

Dimensions $7 \times 10 \mathrm{~cm}$

AMC 24796_1-22-3
Caption Tashi Lama (in chair)

Photographer initialed W.C.

Date ca. 1903-1904

Medium Collodion silver print on printing-out paper.

Dimensions $10 \times 7 \mathrm{~cm}$

AMC 24796_1-23-3 
Caption Snows around Phari

Photographer initialed W.C.

Date ca. 1903-1904

Medium Collodion silver print on printing-out paper.

Dimensions 7 x $10 \mathrm{~cm}$

AMC 24796_1-24-2
Caption Tibetans getting water from springs

Photographer initialed W.C.

Date ca. 1903-1904

Medium Collodion silver print on printing-out paper.

Dimensions $7 \times 10 \mathrm{~cm}$

AMC 24796_1-25-2

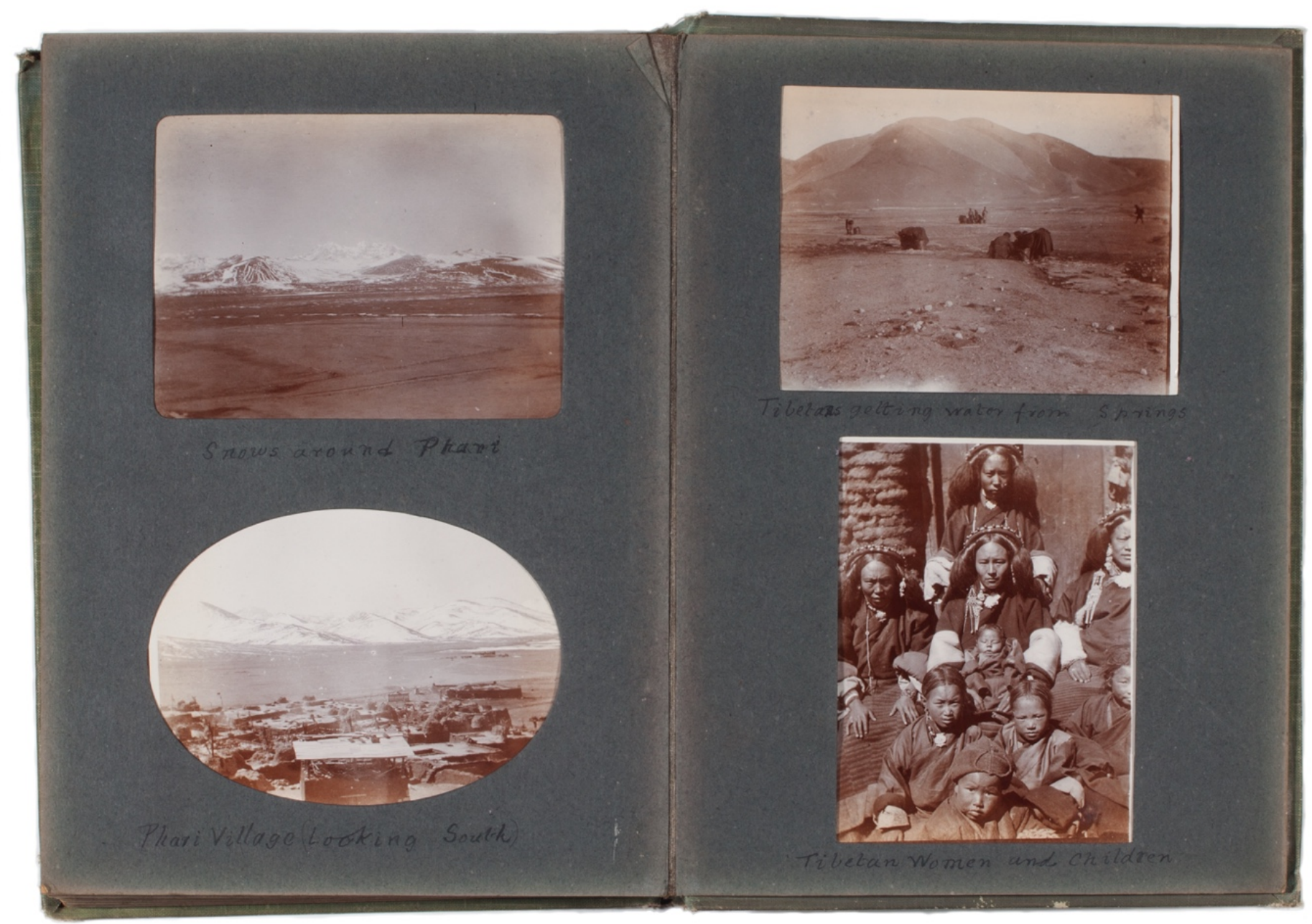

Gaption Phari Village (looking South)

Photographer initialed W.C.

Date ca. 1903-1904

Medium Collodion silver print on printing-out paper.

Dimensions $7 \times 10 \mathrm{~cm}$

AMC 24796_1-24-3
Gaption Tibetan Women and Children

Photographer initialed W.C.

Date ca. 1903-1904

Medium Collodion silver print on printing-out paper.

Dimensions $10 \times 7 \mathrm{~cm}$

AMG 24796_1-25-3 
Caption Chumbi Post (from West)

Photographer initialed W.C.

Date ca. 1903-1904

Medium Collodion silver print on printing-out

paper.

Dimensions $7 \times 10 \mathrm{~cm}$

AMC 24796_1-26-2

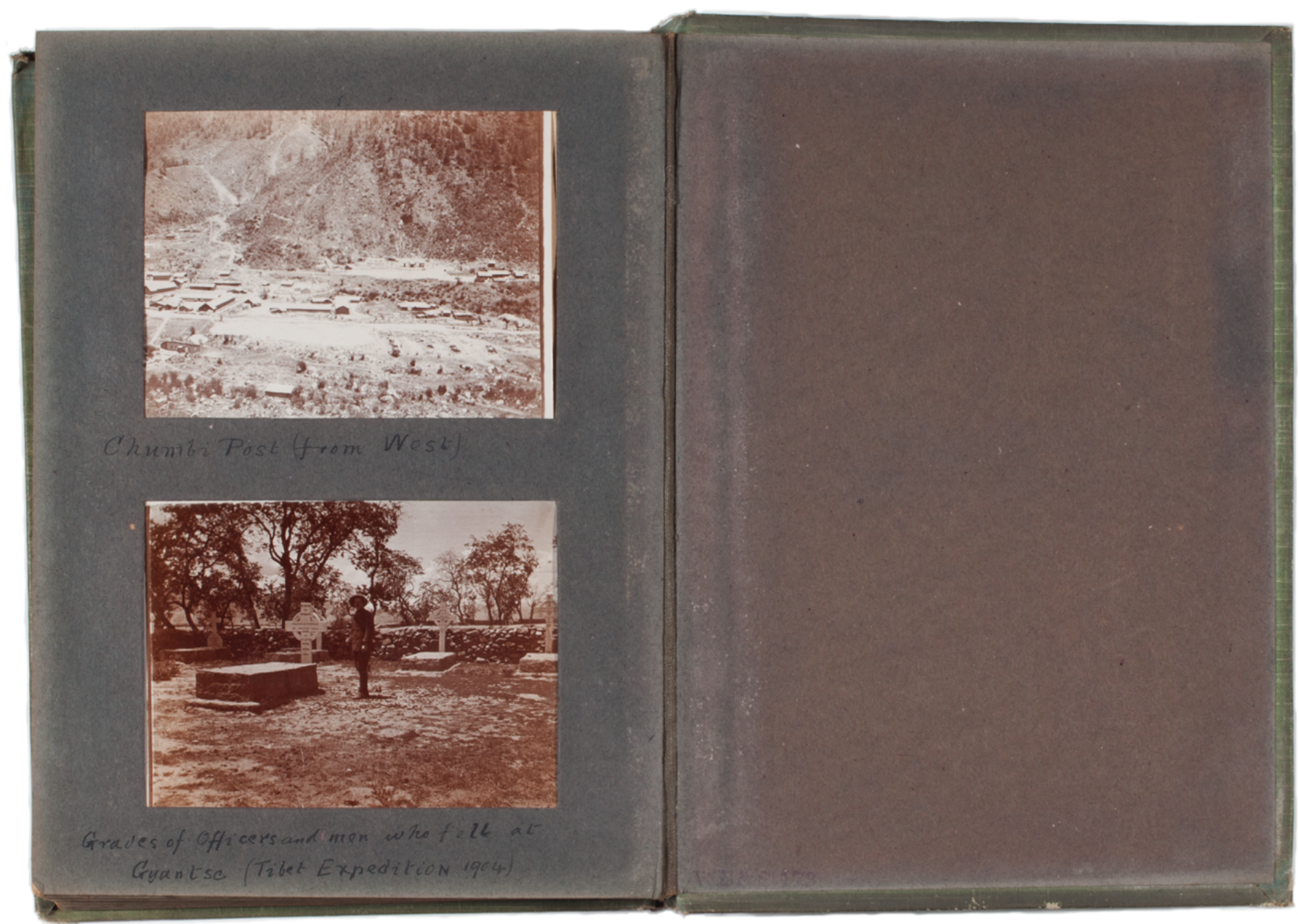

Caption Graves of officers and men who fell at Gyantse (Tibet Expedition 1904)

Photographer initialed W.C.

Date ca. 1903-1904

Medium Collodion silver print on printing-out

paper.

Dimensions 7 x $10 \mathrm{~cm}$

AMC 24796_1-26-3
Description Inside back cover.

\section{Dimensions}

AMG 24796_1-27 
Appendix B Hayman Album Gatalogue

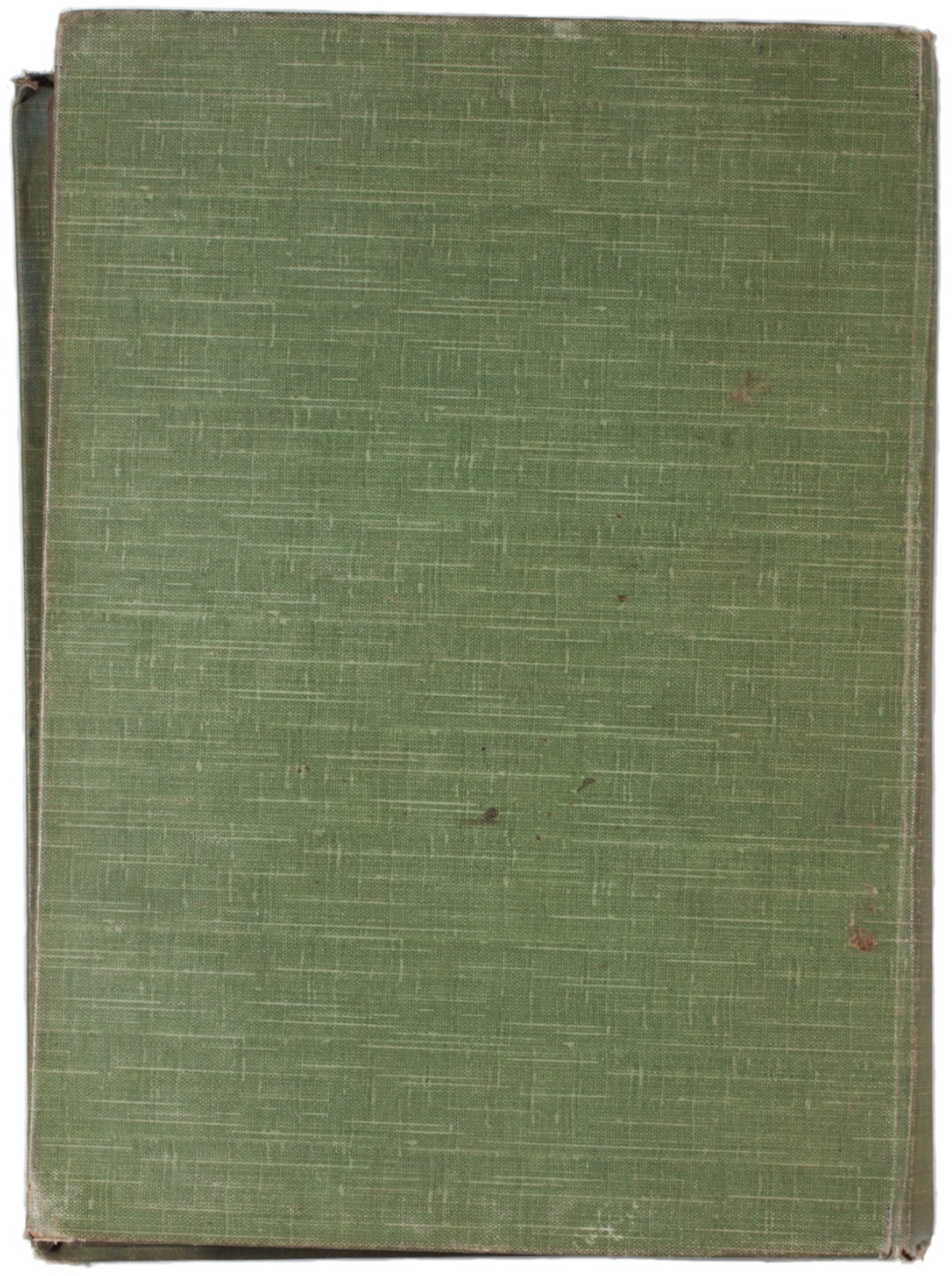

Description Back cover.

Dimensions

AMC 24796_1-28 


\section{Appendix C Transcript of the Convention Between Great Britain and \\ Thibet (1904)}

\section{GONVENTION BETWEEN GREAT BRITAIN AND THIBET}

Signed at Lhasa, 7 September, 1904

Whereas doubts and difficulties have arisen as to the meaning and validity of the Anglo-Chinese Convention of 1890, and the Trade Regulations of 1893, and as to the liabilities of the Thibetan Government under these Agreements; and whereas recent occurrences have tended towards a disturbance of the relations of friendship and good understanding which have existed between the British Government and the Government of Thibet; and whereas it is desirable to restore peace and amicable relations, and to resolve and determine the doubts and difficulties as aforesaid, the said Governments have resolved to conclude a Convention with these objects, and the following Articles have been agreed upon by Colonel F.E. Younghusband, C.I.E., in virtue of full powers vested in him by His Britannic Majesty's Government and on behalf of that said Government, and LoSang Gyal-Tsen, the Ga-den Ti-Rimpoche, and the Representatives of the Council of the three monasteries, Sera, Dre-pung, and Ga-den, and of the ecclesiastical and lay officials of the National Assembly on behalf of the Government of Thibet.

I. The Government of Thibet engages to respect the Anglo-Chinese Convention of 1890 and to recognize the frontier between Sikkim and Thibet, as defined in Article I of the said Convention, and to erect boundary pillars accordingly.

II. The Thibetan Government undertakes to open forthwith trade marts to which all British and Thibetan subjects shall have free right of access at Gyangtse and Gartok, as well as at Yatung.

The Regulations applicable to the trade mart at Yatung, under the Anglo-Chinese Agreement of 1893, shag, subject to such amendments as may hereafter be agreed upon by common consent between the British and Thibetan Governments, apply to the marts above mentioned.

In addition to establishing trade marts at the places mentioned, the Thibetan Government undertakes to place no restrictions on the trade by existing routes, and to consider the question of establishing fresh trade marts under similar conditions if development of trade requires it.

III. The question of the amendment of the Regulations of 1893 is reserved for separate consideration, and the Thibetan Government undertakes to appoint fully authorized Delegates to negotiate with the Representatives of the British Government as to the details of the amendments required.

IV. The Thibetan Government undertakes to levy no dues of any kind other than those provided for in the tariff to be mutually agreed upon.

V. The Thibetan Government undertakes to keep the roads to Gyangtse and Gartok from the frontier clear of all obstruction and in a state of repair suited to the needs of the trade, and to establish at Yatung, Gyangtse, and Gartok, and at each of the other trade marts that may hereafter be established, a Thibetan Agent, who shall receive from the British Agent appointed to watch over British trade at the marts in question any letter which the latter may desire to send to 


\section{Appendix C Transcript of the Convention Between Great Britain and}

Thibet (1904)

the Thibetan or to the Chinese authorities. The Thibetan Agent shall also be responsible for the due delivery of such communications and for the transmission of replies.

VI. As an indemnity to the British Government for the expense incurred in the dispatch of armed troops to Lhasa, to exact reparation for breaches of Treaty obligations and for the insults offered to and attacks upon the British Commissioner and his following and escort, the Thibetan Government engages to pay a sum of 500,0001.--equivalent to 75 lakhs of rupees--to the British Government.

The indemnity shall be payable at such places as the British Government may from time to time, after due notice, indicate, whether in Thibet or in the British districts of Darjeeling or Jalpaiguri, in seventy-five annual installments of 1 lakh of rupees each, on the 1st January in each year, beginning from the 1st January, 1906.

VII. As security for the payment of the above-mentioned indemnity and for the fulfillment of the provisions relative to trade marts specified in Articles II, III, IV and V, the British Government shall continue to occupy the Chumbi Valley until the indemnity has been paid, and until the trade marts have been effectively opened for three years, whichever date may be the later.

VIII. The Thibetan Government agrees to raze all forts and fortifications and remove all armaments which might impede the course of free communication between the British frontier and the towns of Gyangtse and Lhassa.

IX. The Government of Thibet engages that, without the previous consent of the British Government.

a. No portion of Thibetan territory shall be ceded, sold, leased, mortgaged or otherwise given for occupation, to any foreign Power;

b. No such Power shall be permitted to intervene in Thibetan affairs;

c. No Representatives or Agents of any foreign Power shall be admitted to Thibet;

d. No concessions for railways, roads, telegraphs, mining or other rights, shall be granted to any foreign Power, or the subject of any foreign Power. In the event of consent to such concessions being granted, similar or equivalent concessions shall be granted to the British Government;

e. No Thibetan revenues, whether in kind or in cash, shall be pledged or assigned to any foreign Power, or to the subject of any foreign Power.

$\mathrm{X}$. In witness whereof the negotiators have signed the same, and affixed thereunto the seals of their arms.

Done in quintuplicate at Lhassa, this 7th day of September, in the year of our Lord 1904, corresponding with the Thibetan date, the 27 th of the 7 th month of the Wood Dragon year. 


\section{Appendix C Transcript of the Convention Between Great Britain and

(Seal of Dalai Lama, affixed by the Ga-den Ti-Rimpoche)

(Seal of Thibet Frontier Commission)

(Seal of British Commissioner)

(Seal of Council)

(Seal of the Dre-pung Monastery)

(Seal of Se-ra Monastery)

(Seal of Ga-den Monastery)

(Seal of National Assembly)

F.E. Younghusband, Colonel,

British Commissioner

In proceeding to the signature of the Convention, dated this day, the Representatives of Great Britain and Thibet declare that the English text shall be binding.

(Seal of Dalai Lama, affixed by the Ga-den Ti-Rimpoche)

(Seal of Thibet Frontier Commission)

(Seal of British Commissioner)

(Seal of Council)

(Seal of Dre-pung Monastery)

(Seal of Se-ra Monastery)

(Seal of Ga-den Monastery)

(Seal of National Assembly)

F.E. Younghusband, Colonel,

British Commissioner

Ampthill,

Viceroy and Governor-General of India 


\section{Appendix C Transcript of the Convention Between Great Britain and}

Thibet (1904)

This Convention was ratified by the Viceroy and Governor-General of India in Council at Simla on the llth day of November, A.D. 1904.

\section{S.M. Fraser}

Secretary to the Government of India

(Foreign Department)

Declaration Signed by his Excellency the Viceroy

and Governor-General of India on the 11 November, 1904,

and Appended to the Ratified Convention

of 7 September, 1904

His Excellency the Viceroy and Governor-General of India, having ratified the Convention which was concluded at Lhassa on 7th September, 1904, by Colonel Younghusband, C.I.E., British Commissioner for Thibet Frontier Matters, on behalf of His Britannic Majesty's Government; and by Lo-Sang Gyal-Tsen, the Ga-den Ti-Rimpoche, and the Representatives of the Council, of the three Monasteries Sera, Dre,pung, and Ga-den, and of the ecclesiastical and lay officials of the National Assembly, on behalf of the Government of Thibet, is pleased to direct as an act of grace that the sum of money which the Thibetan Government have bound themselves under the terms of Article VI of the said Convention to pay to His Majesty's Government as an indemnity for the expenses incurred by the latter in connection with the dispatch of armed forces to Lhassa be reduced from 75,00,000 rupees to 25,00,000 rupees; and to declare that the British occupation of the Chumbi valley shall cease after the due payment of three annual installments of the said indemnity as fixed by the said Article: Provided, however, that the trade marts as stipulated in Article ][p.I of the Convention shall have been effectively opened for three years as provided in Article VI of the Convention; and that, in the meantime, the Thibetans shall have faithfully complied with the terms of the said Convention in all other respects.

Ampthill,

Viceroy and Governor-General of India ${ }^{114}$

\footnotetext{
${ }^{114}$ Reproduced from M. C. van Walt van Praag's Status of Tibet: History, Rights and Prospects in International Law (Boulder: Westview Press, 1987).
} 


\section{Appendix D Matching Photograph Variants by Caption \& Identifier}

\begin{tabular}{|c|c|c|c|}
\hline \multicolumn{2}{|c|}{$\begin{array}{l}\text { Album From Tibet Expedition, } \\
\qquad 1904\end{array}$} & \multicolumn{2}{|c|}{ Hayman Album } \\
\hline AMC Identifier & Caption & AMC Identifier & Caption \\
\hline 22680_1-5 & $\begin{array}{l}\text { Phari Village (Tibet) in } \\
\text { winter }\end{array}$ & 24796_1-7-2 & $\begin{array}{l}\text { Phari Village in winter } \\
\text { (looking North) }\end{array}$ \\
\hline 22680_1-6 & Chumbi Post (Tibet) & 24796_1-5-2 & Chumbi, Tibet \\
\hline 22680_1-7 & $\begin{array}{l}\text { Gyantse Jong (Fort) } \\
\text { (Tibet) }\end{array}$ & 24796_1-11-2 & $\begin{array}{l}\text { Gyantse Jong Fort (from } \\
\text { the East) }\end{array}$ \\
\hline 22680_1-8 & Tibetan Women & 24796_1-5-3 & Tibetan Women \\
\hline 22680_1-9 & Street Scene (Tibet) & 24796_1-9-3 & Street Scene (Tibet) \\
\hline 22680_1-10 & $\begin{array}{l}\text { Field Telegraph Office } \\
\text { Phari (Tibet) }\end{array}$ & 24796_1-9-2 & $\begin{array}{l}\text { Field Telegraph Office } \\
\text { (Phari) }\end{array}$ \\
\hline 22680_1-11 & Tibetan Urchins & 24796_1-6-2 & Tibetan Urchins \\
\hline 22690_1-12 & Teesta Bridge (Sikkim) & 24796_1-3-2 & Teesta Bridge, Sikkim \\
\hline 22680_1-13 & Tibetans holiday making & 24796_1-13-2 & Tibetans Holiday Making \\
\hline 22680_1-14 & A Takin of Bhutan & 24796_1-8-3 & A Takin of Bhutan \\
\hline 22680_1-15 & $\begin{array}{l}\text { Tent of Tashi Lama } \\
\text { (Tibet) (Leopard skins) }\end{array}$ & 24796_1-7-3 & $\begin{array}{l}\text { Tashi Lama's Tent } \\
\text { (Leopard Skin) }\end{array}$ \\
\hline 22680_1-16 & $\begin{array}{l}\text { Commissariat Godown } \\
\text { Chumbi (Tibet) }\end{array}$ & 24796_1-6-3 & $\begin{array}{l}\text { Coms't Godowns, } \\
\text { Chumbi }\end{array}$ \\
\hline 22680_1-17 & $\begin{array}{l}\text { The Amo Cha River } \\
\text { (Chumbi Valley) }\end{array}$ & 24796_1-4-2 & $\begin{array}{l}\text { The Amo Cha River, } \\
\text { Tibet }\end{array}$ \\
\hline 22680_1-18 & $\begin{array}{l}\text { Ruins of Phari Jong } \\
\text { (Tibet) }\end{array}$ & 24796_1-12-2 & Ruins of Phari Jong \\
\hline 22680_1-19 & $\begin{array}{l}\text { A Corner of Phari Village } \\
\text { (in winter) }\end{array}$ & 24796_1-10-3 & $\begin{array}{l}\text { Phari Village (looking } \\
\text { S.W.) }\end{array}$ \\
\hline 22680_1-20 & $\begin{array}{l}\text { Group of Tibetan } \\
\text { Women + Children }\end{array}$ & 24796_1-10-2 & A Group of Tibetans \\
\hline 22680_1-21 & Bazaar at Phari & 24796_1-18-2 & Bazaar at Phari \\
\hline 22680_1-22 & $\begin{array}{l}\text { Monastery at Gyantse } \\
\text { (Tibet) }\end{array}$ & 24796_1-11-3 & Tibetan Monastery \\
\hline 22680_1-23 & $\begin{array}{l}\text { Cantilever Bridge } \\
\text { (Chumbi Valley) }\end{array}$ & 24796_1-4-3 & $\begin{array}{l}\text { Cantilever Bridge, } \\
\text { Chumbi }\end{array}$ \\
\hline 22680_1-24 & $\begin{array}{l}\text { Phema Village, Chumbi } \\
\text { Valley (Tibet) }\end{array}$ & 24796_1-8-2 & Phema Village (Tibet) \\
\hline 22680_1-25 & $\begin{array}{l}\text { Political officer's house } \\
\text { (Chumbi) }\end{array}$ & 24796_1-3-3 & $\begin{array}{l}\text { The Residency, Chumbi, } \\
\text { Tibet }\end{array}$ \\
\hline 22680_1-26 & $\begin{array}{l}\text { Chumbi Valley (showing } \\
\text { Amo Cha) }\end{array}$ & 24796_1-12-3 & $\begin{array}{l}\text { Chumbi Valley (looking } \\
\mathrm{N} \text { ) }\end{array}$ \\
\hline 22680_1-27 & Tibetan Girl & 24796_1-15-3 & Tibetan Girl \\
\hline $22680 \_1-28$ & $\begin{array}{l}\text { British NCO's Quarters } \\
\text { (Chumbi) }\end{array}$ & 24796_1-14-3 & $\begin{array}{l}\text { British NCO's Qrs, } \\
\text { Chumbi }\end{array}$ \\
\hline 22680_1-29 & Ju-Sa Village (Chumbi) & 24796_1-15-2 & Yu Sa Village (Tibet) \\
\hline 22680_1-30 & $\begin{array}{l}\text { Native Troops Lines, } \\
\text { Phari (Tibet) }\end{array}$ & 24796_1-19-3 & Sepoys Lines, Phari \\
\hline 22680_1-31 & $\begin{array}{l}\text { Tibetans Awaiting Grand } \\
\text { Lama's Arrival }\end{array}$ & 24796_1-13-3 & $\begin{array}{l}\text { Tibetans awaiting Tashi } \\
\text { Lama's arrival } \\
\text { (Chumulhari Mtn in } \\
\text { background, } 24100 \mathrm{ft} \text { ) }\end{array}$ \\
\hline 22680_1-32 & $\begin{array}{l}\text { Bridge over "Tsan-po" } \\
\text { Gyantse (Tibet) }\end{array}$ & 24796_1-18-3 & $\begin{array}{l}\text { Bridges over Tsanpo, } \\
\text { Gyantse }\end{array}$ \\
\hline 22680_1-33 & Slaughtered Yaks & 24796_1-20-2 & Yaks slaughtered for food \\
\hline
\end{tabular}




\section{Appendix D Matching Photograph Variants by Caption \& Identifier}

\begin{tabular}{|c|c|c|c|}
\hline & & & for British Troops (Tibet) \\
\hline 22680_1-34 & $\begin{array}{l}\text { Field Telephone at Work } \\
\text { (Tibet Exp. 1904) }\end{array}$ & 24796_1-16-2 & $\begin{array}{l}\text { Field Telegraph at Work } \\
\text { (Tibetan Expedition } 1904\end{array}$ \\
\hline 22680_1-35 & Grand Lama of Tibet & 24796_1-23-3 & Tashi Lama (in chair) \\
\hline 22680_1-36 & $\begin{array}{l}\text { Phari Village (Tibet) } \\
\text { during winter }\end{array}$ & 24796_1-22-2 & Phari Village (from Jong) \\
\hline 22680_1-37 & $\begin{array}{l}\text { Field Telegraph of } \\
\text { Chumbi (Tibet) }\end{array}$ & 24796_1-22-3 & $\begin{array}{l}\text { Field Telegraph Office } \\
\text { (Chumbi) }\end{array}$ \\
\hline 22680_1-38 & $\begin{array}{l}\text { Snow Range Near Phari } \\
\text { (Tibet) }\end{array}$ & 24796_1-24-3 & $\begin{array}{l}\text { Phari Village (Looking } \\
\text { South) }\end{array}$ \\
\hline 22680_1-39 & $\begin{array}{l}\text { Gyantse Jong (Fort) } \\
\text { Gyantse (Tibet) }\end{array}$ & 24796_1-21-2 & Gyantse Jong (front view) \\
\hline 22680_1-40 & $\begin{array}{l}\text { General view (Chumbi } \\
\text { Valley) }\end{array}$ & 24796_1-16-3 & $\begin{array}{l}\text { Chumbi Valley (from } \\
\text { Heights) }\end{array}$ \\
\hline $22680-1-41$ & $\begin{array}{l}\text { Tibetan women + } \\
\text { children }\end{array}$ & 24796_1-25-3 & $\begin{array}{l}\text { Tibetan Women and } \\
\text { Children }\end{array}$ \\
\hline 22680_1-42 & $\begin{array}{l}\text { Tibetan getting water } \\
\text { from springs }\end{array}$ & 24796_1-25-2 & $\begin{array}{l}\text { Tibetans getting water } \\
\text { from springs }\end{array}$ \\
\hline 22680_1-43 & $\begin{array}{l}\text { General View of Chumbi } \\
\text { (Tibet) }\end{array}$ & 24796_1-26-2 & Chumbi Post (from West) \\
\hline 22680_1-44 & $\begin{array}{l}\text { Snow Range near Phari } \\
\text { (Tibet) }\end{array}$ & 24796_1-24-2 & Snows around Phari \\
\hline 22680_1-45 & $\begin{array}{l}\text { Graces of officers and } \\
\text { men who fell during the } \\
\text { Tibet Expedition } 1904\end{array}$ & 24796_1-26-3 & $\begin{array}{l}\text { Graves of officers and } \\
\text { men who fell at Gyantse } \\
\text { (Tibet Expedition 1904) }\end{array}$ \\
\hline 22680_1-46 & $\begin{array}{l}\text { Native Troops drawing } \\
\text { Rum (Tibet) }\end{array}$ & 24796_1-20-3 & $\begin{array}{l}\text { Native Troops drawing } \\
\text { Rum }\end{array}$ \\
\hline 22680_1-47 & $\begin{array}{l}\text { Transport section, Native } \\
\text { F. Hosp'l (Tibet) }\end{array}$ & 24796_1-14-2 & $\begin{array}{l}\text { Transport, Native Field } \\
\text { Hospital }\end{array}$ \\
\hline 22680_1-48 & $\begin{array}{l}\text { General view Chumbi } \\
\text { Valley }\end{array}$ & 24796_1-17-3 & $\begin{array}{l}\text { Chumbi Valley (from } \\
\text { heights) }\end{array}$ \\
\hline 22680_1-49 & $\begin{array}{l}\text { Telegraph Staff, Phari } \\
\text { (Tibet) }\end{array}$ & 24796_1-19-2 & Telegraph Staff, Phari \\
\hline 22680_1-50 & Nepalese Woman & 24796_1-21-3 & Nepalese Woman \\
\hline 22680_1-51 & Palla Village (Tibet) & 24796_1-17-2 & $\begin{array}{l}\text { Phari Village (from } \\
\text { Gyantse Jong) }\end{array}$ \\
\hline 22680_1-52 & $\begin{array}{l}\text { M.I. Tibet Expedition } \\
1904\end{array}$ & 24796_1-23-2 & $\begin{array}{l}\text { M.I. Reconnoit[e]ring } \\
\text { (Tibet Expedition) }\end{array}$ \\
\hline
\end{tabular}


Allum, Mark. "Tibetan Travesty." In Allum's Antiques Almanac 2015: An Annual Compendium of Stories and Facts from the World of Art and Antiques. London: Icon Books Ltd, 2015.

Antiques Trade Gazette. "Photo Album Reveals a Bloody Expedition into Tibet." Last modified August 19, 2013. Accessed June 20, 2016. https://www.antiquestradegazette.com/news/2013/photo-album-reveals-a-bloodyexpedition-into-tibet/

Banerjee, Sukanya. Becoming Imperial Citizens: Indians in the Late-Victorian Empire. Durham: Duke University Press, 2010.

Banks, Marcus, and Jay Ruby, ed. Made to Be Seen: Perspectives on the History of Visual Anthropology. Chicago: University of Chicago Press, 2011.

Bear, Jordan. Disillusioned: Victorian Photography and the Discerning Subject. Pennsylvania: The Pennsylvania State University Press, 2015.

Behdad, Ali, and Luke Gartland, ed. Photography's Orientalism: New Essays on Colonial Representation. Los Angeles: Getty Research Institute, 2013.

Bonham's. "Lot 224.” Accessed July 1, 2016. http://www.bonhams.com/auctions/18061/lot/224/

_. "Lot 353." Accessed June 28, 2016. https://www.bonhams.com/auctions/19952/lot/353/

Bonvalot, Gabriel. Across Thibet. Translated by C.B. Pitman. New York: Cassell Publishing Company, 1892.

Chaudhary, Zahid R. Afterimage of Empire: Photography in Nineteenth-Century India. Minneapolis: University of Minnesota Press, 2012.

Coke, Van Deren, ed. One Hundred Years of Photographic History: Essays in Honor of Beaumont Newhall. Albequerque: University of New Mexico Press, 1975.

Connerton, Paul. How Societies Remember. Cambridge: Cambridge University Press, 1989.

Edmonds, Lizzie. "Monasteries, lamas and a convoy of mules: Fascinating glimpse inside the mysterious Forbidden City of Tibet through they eyes of British soldiers over a hundred years ago," The Daily Mail, September 18, 2013. Accessed March 10, 2016. http:/ / www.dailymail.co.uk/news/article-2424330/Monasteries-lamas-convoy-mulesFascinating-glimpse-inside-mysterious-Forbidden-City-Tibet-eyes-British-soldiers-yearsago.html 
Edwards, Elizabeth. Anthropology and Photography, 1860-1920. New Haven: Yale University Press, 1994.

. "Photographs. Mounts, and the Tactile Archive." Interdisciplinary Studies in the Long Nineteenth Century 19 (2014). Accessed January 30, 2016. http://19.bbk.ac.uk

. "Photography and the Material Performance of the Past." History and Theory 48 (2009): $130-150$.

— . "Photographic Uncertainties: Between Evidence and Reassurance." History and Anthropology 25.2 (2014): 171-188.

. Raw Histories: Photographs, Anthropology and Museums. Oxford: Berg, 2001.

Edwards, Elizabeth, and Janice Hart, ed. Photographs Objects Histories: On the Materiality of Images. New York: Routledge, 2004.

Falconer, John. India: Pioneering Photographers, 1859-1900. London: The British Library, 2001.

Falconer, John and Louise Hide. Points of View: Capturing the $19^{\text {th }}$ Century in Photographs. London: The British Library, 2009.

Fleming, Peter. Bayonets to Lhasa: The British Invasion of Tibet. London: Rupert Hart-David Ltd., 1961.

French, Patrick. Younghusband: The Last Great Imperial Adventurer. London: HarperCollins Publishers, 1994.

Hannavy, John, ed. Encyclopedia of Nineteenth-Century Photography. New York: Routledge, 2008.

Harris, Clare E. "In and Out of Place: Tibetan Artists' Travels in the Contemporary Art World." Visual Anthropology Review 28.2 (2012): 152-163.

. The Museum on the Roof of the World: Art, Politics, and the Representation of Tibet.

Chicago: University of Chicago Press, 2012.

— . "The Buddha Goes Global: Some Thoughts Towards a Transnational Art History." Art History 29.4 (2006): 698-720.

Harris, Clare E., and Tsering Shakya. Seeing Lhasa: British Depictions of the Tibetan Capital, 19361947. Chicago: Serinda Publications, 2003.

Harris, Clare E., and Michael O'Hanion. "The Future of the Ethnographic Museum.” Anthropology Today 29.1 (2013): 8-12.

Hight, Eleanor M., and Gary D. Sampson, ed., Colonialist Photography: Imag(in)ing Race and Place. London: Routledge, 2004. 
Hoffman, Michael E. Tibet: The Sacred Realm. New York: Aperture, 1983.

Hopkirk, Peter. The Great Game: The Struggle for Empire in Central Asia. New York: Kodansha USA, Inc., 1994.

- Trespassers on the Roof of the World: The Secret Exploration of Tibet. London: John Murray, 1982.

Jay, Martin and Samathi Ramaswamy, ed. Empires of Vision: A Reader. Durham: Duke University Press, 2014.

Johnson, William S., ed. Nineteenth-century photography: an annotated bibliography 1839-1879. London: Mansell Publishing Limited, 1990.

Meyer, Kurt, and Pamela Deuel Meyer. In the Shadow of the Himalayas: A Photographic Record by John Claude White. Ahmedebad: Mapin Publishing, 2006.

Pelizzari, Maria Antonella, ed. Traces of India: Photography, Architecture, and the Politics of Representation, 1850-1900. Montréal: Canadian Centre for Architecture, 2003.

Pinney, Christopher, and Nicolas Peterson, ed. Photography's Other Histories. Durham: Duke University Press, 2003.

Reilly, James R. Care and Identification of $19^{\text {th }}$ Century Photographic Prints. Rochester: Eastman Kodak Company, 1986.

Ryan, James. Photography and Exploration. London: Reaktion Books, 2013,

Picture Empire: Photography and the Visualization of the British Empire. Chicago: University of Chicago Press, 1998.

Ryan, James R., and Joan Schwartz, ed. Picturing Place: Photography and the Geographical Imagination. London: I.B. Tauris \& Co Ltd, 2003.

Stocking Jr., George W., ed. Objects and Others: Essays on Museums and Material Culture. Madison: The University of Wisconsin Press, 1985.

Taylor, Roger. Impressed by Light: British Photographs from Paper Negatives, 1840-1860. New York: The Metropolitan Museum of Art, 2007.

Tibetan Young Buddhist Assocation. Tibet: The Facts. Dharamsala: Indrapastha Press, 1990.

Watson, J. Forbes, and John William Kaye, ed. The People of India. London: India Museum, 1868.

White, John Claude. Sikhim \&̊ Bhutan: Twenty-One Years on the North-East Frontier, 1887-1908. London: Arnold, 1909. 
- Tibet Album. Calcutta: Johnston \& Hoffman, 1908.

. "World's Strangest Capital.” National Geographic 29 (March 1916): 273-95.

Worswick, Clark. The Last Empire: Photography in British India, 1855-1911. New York: Aperture, 1976.

Younghusband, Francis Edward. India and Tibet: A History of the Relations Which Have Subsisted Between the Two Countries from the Time of Warren Hastings to 1910; With a Particular Account of the Mission to Lhasa of 1904. London: J. Murray, 1909. 